\title{
THE-RIVERSIDE-LIBRARY FOR.YOUNG.PEOPLE
}

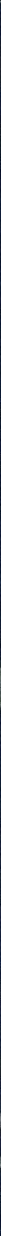



Au 




\section{The latorersido 1 library for 其oung jarople}

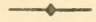

Number 3

BIRDS THROUGH AN OPERA-GLASS

By FLORENCE A. MERRIAM

\&ै 



\section{BIRDS}

\section{THROUGH AN OPERA-GLASS}

BY

FLORENCE A. MERRIAM

Bailey, Florence merriam.

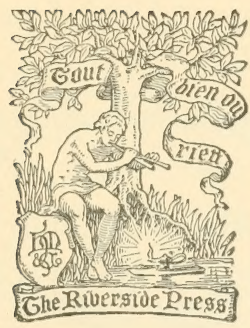

BOSTON AND NEW YORK HOUGHTON, MIFFLIN AND COMPANY

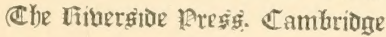
I 898 
Copyright, 1889 ,

Bx FLORENCE A. MERRIAM.

All rights reserved.

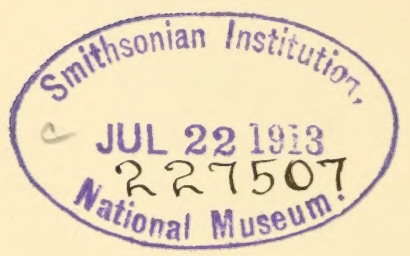

The Riverside Press, Cambridge, Mass., U. S. A. Electroty ped and Printed by H. O. Houghton \& Company. 


\section{PREFACE.}

Lrke Snug the joiner, in Midsummer Night's Dream, I would explain to the ladies at the outset that this little book is no real lion, and that they have nothing to fear. It is not an ornithological treatise. It has not even the lion's roar of technical terms and descriptions to warn them of raging dulness, but is "a very gentle beast. and of a good conscience."

It was my good fortune when in college to be able to study the perplexities of nearly forty young observers, and this book is virtually the result of what I learned of their wants and the best ways to supply them. Equipped with operaglasses, we worked together in the woods and fields, and books were rarely consulted; but when I was asked "How are we to know the birds at home, where we have no one to help us?" I saw their need of books. But what could they use? Few of those who want to know the birds have time or inclination to become ornithologists, or 
even to master the vocabulary of ornithology which would enable them to use the expensive Keys and Manuals for identifying birds. This, then, is what I have tried to do: To furnish hints that will enable not only young observers but also laymen to know the common birds they see about them.

Hints, I offer ; nothing more. Many birds I leave ummentioned, because they have never chanced to come before my opera-glass; and often my own local experiences ${ }^{1}$ are given instead of generalizations, because habits vary greatly in different sections, as in the case of the catbird, who shums all habitations in Louisiana while he is a familiar village gossip in the north and east, and I would hold to my boast of a "good conscience." I tell the truth about what I have seen through my own Toigtlander and Solm, - a most excellent make of glass, by the way, - and leave earnest observer's to see and learn more for themselves.

Nevertheless, it is not merely those who can go

1 My notes were made either at Northampton, Massachusetts, or Locust Grove, New York. The latter place is in the Black River Valley, on the western border of the Adirondacks, and may always be understood, not only when the word " here " is used, but in all cases where no locality is specified. 
to see for themselves I would tell of my walks; it is above all the careworn indoor workers to whom I would bring a breath of the woods, pictures of sumlit fields, and a hint of the simple, childlike gladness, the peace and comfort that is offered us every day by these blessed winged messengers of nature.

Many of the articles herein contained were published in the Audubon Magarine in 1886. These have been revised and largely rewritten. The others now appear for the first time. The illustrations are from Baird, Brewer and Ridgway's History of North American Birds. For' permission to use them I am indebted to $\mathrm{Mr}$. Ridgway.

Loctst Grove, New York, January, 1888. 



\section{HINTS TO OBSERVERS.}

WHeN you begin to study the birds in the fields and woods, to guard against scaring the wary, you should make yourself as much as possible a part of the landscape. Most birds are not afraid of man as a figure, but as an aggressive object.

The observance of a few simple rules will help you to be unobtrusive.

First. Aroid light or bright-colored clothing. A dull-colored jacket and an old leaf-colored hat that you can pull over the eyes or push back from the face as the light requires, will do excellent service if you to not wish a complete suit.

Second. Walk slowly and noiselessly. Among the crisp rattling leaves of the woods, a bit of moss or an old log will often deaden your step at the critical moment.

Thirrl. Avoid all quick, jerky motions. How many lirds I have seared away by raising my glass too suddenly!

Fourth. Avoid all talking, or speak only in an undertone - a most obnoxious but important rule to young observers.

Fifth. If the bird was singing, but stops on your approach, stand still a moment and encourage him by answering his call. If he gets interested he will often let you creep up within opera-glass distance. Some of the most charming snatches of friendly talk will come at such times.

Sixth. Make a practice of stopping often and standing perfectly still. In that way you hear voices that would be lost if you were walking, and the birds come to the spot 
without noticing you when they would fly away in advance if they were to see or hear you coming toward them.

Seventh. Conceal yourself by leaning against a tree, or pulling a branch down in front of you. The best way of all is to select a good place and sit there quietly for several hours, to see what will come. Then you get at the home life of the birds, not merely seeing them when they are on their guard. A low stump in a raspberry patch and a log in an alder swamp prove most profitable seats.

In going to look for birds it is important to consider the time of day, and the weather. Birds usually follow the sum. In spring and fall you will find them in the fields and orchards early in the morning, but when the sum has warmed the south sic.e of the woods they go there; and in the aftemoon they follow it across to the north side. During heavy winds and storms you are most likely to find birds well under cover of the woods, no matter at what time of day; and then, often on the side opposite that from which the wind comes.

For careful observation in general, three rules may be given.

1. In clear weather be sure to get between the sun and your bird. In the wrong light a scarlet tanager or a bluebird will look as black as a crow.

2. Gaze. Let your eyes rest on the trees before your, and if a leaf stirs, or a twig sways, you will soon rliscover your bircl. At a little distance, it is well to gaze through your glass.

3. Beware of the besetting sin of observers. Never jump at conclusions. Prove all your conjectures. 


\section{CONTENTS.}

CHAP.

PAGE

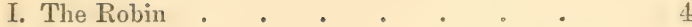

II. The Crow . . . . . . . 10

III. The Blnebird . . • . • 。 14

IV. The Chimney Swift; Chimney "Swallow" . 16

V. Catbird . . . . . . . . 18

VI. Keel-Tailed Blackbird; Crow Blackbird; Bronzed

Grackle • • . . . • . 20

VII. Bobolink; Reed-Bird; Rice-Bird . . . 27

VIII. Ruffed Grouse; Partridge . . . , @;:

IX. Ruby-Throated Humming-Bird . . . . 36

X. Meadow-Lark . . . . . . . 40

XI. Black-Capped Chickadee; Titmouse . . . 42

XII. Cuckoo; Rain Crow . . . . . . 46

XIII. Yellow Hammer; Flicker . . . . . 45

XIV. Baltimore Oriole; Fire-Bird; Golden Robin; HangNest . . . . . 5

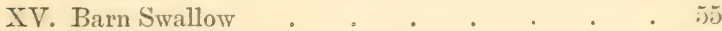

XVT. Belted Kingfisher 。 . . . . . . 5

XVII. Chip-Bird or Chippy; Hair-Bird; Chipping Sparrow; Social Sparrow . . . . . . 60

XVIII. Song Sparrow . . . . . . . .

XIX. Blue Jay • • • • • • • 。 (5!)

XX. Yellow-Bird; American Goldfinch; Thistle-Birl it

XXI. Phœbe . . . . . . . 80

XXII. King-Bird; Bee Martin . . . . . s:?

XXIII. Wood Pewee . . . . . . . \&.

XXIV. Least Flycatcher . . . . . . . $\$$

XXV. Red-Winged Blackloird . . . . . \&?

XXVI. Hairy Woodpecker . . . . . . 9.2 
XXVII. Downy Woodpecker . . . . $\quad$ • 99

XXVIII. White-Bellied Nuthatch; Devil-Down Head . 100

XXIX. Cowbird . . . . . . . 105

XXX. White-Throated Sparrow . . . 109

XXXI. Cedar-Bird; Waxwing . . . . 112

XXXII. Chewink; Towhee . . . . . . 115

XXXIII. Indigo-Bird . . . . . . 119

XXXIV. Purple Finch • • . . . . 122

XXXV. Red-Eyed Vireo . . . . . . 124

XXXVI. Yellow-Throated Vireo . . . . . 129

XXXVII. Warbling Vireo . . . . . . 131

XXXVIII. Oven-Bird; Golden-Crowned Thush . . 132

XXXIX. Junco; Slate-Colored Snowbird . • . 138

XL. Kinglets . . . . . . . . 140

XLI. Snow Bunting; Snowflake . . . . 144

XLII. Searlet Tanager . . . . • 146

XLIII. Brown Thrasher . • . . . . 150

XLIV. Rose-Breasted Grosbeak . . . . . 153

XLV. Whippoorwill . . . . . . 155

XLVI. Winter, Wren . . . . . . 155

XLVII. Red-Headed Woodpecker . . . $\quad 159$

XLVIII. Yellow-Bellied Sapsucker . . • . 160

XLIX. Great-Crested Flycatcher . . . . 163

L. Bank Swallow; Sand Martin . . . . 165

LI. Cave Swallow ; Cliff Swallow . . . 166

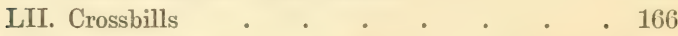

LIII. Night-Hawk; Bull Bat . . . . 169

LIV. Grass Finch; Vesper Sparrow; Bay-IVinged

Bunting . . . . . . . 171

LV. Tree Sparrow . . . . . . 172

LVI White-Crowned Sparrow . . . . . 173

LVII. Field Sparrow; Bush Sparrow . . . 174

LVIII. Fox Sparrow . . . . . . . 175

LIX. Brown Creeper . . . . . . 176

IVARBLERS.

LX. Summer Yellow-Bird; Golden Warbler; Yellow Warbler. . . . . . . 179

LXI. Redstart . . . . . . . 180 
LXII. Black and White Creeping Warbler . . 184 LXIII. Blackburnian Warbler; Hemlock Warbler;

Orange-Throated Warbler • • 186

LXIV. Black-Throated Blue Warbler . . 187

LXV. Yellow Rumped Warbler; Myrtle Warbler 189

LXVI. Chestnut-Sided Warbler . . . . . 190

i.XVII. Maryland Yellow-Throat; Black Masked

Ground Warbler • • • • • 191

LXVIII. Thrushes. • • . • . . . 193

LXIX. Wilson's Thrush; Veery; Tawny Thrush . 198

LXX. Hermit Thrush . • • • • . 202

\section{APPENDIX.}

Pigeon-Holes for the Perching Birds mentioned in this book . . . . . . . . 206

General Family Characteristies of Birds Treated . . 208 Arbitrary Classifications of Birds Described . . . 211 Books for Reference . . . . . . . 220 



\section{BIRDS THROUGH AN OPERA-GLASS.}

WE are so in the habit of focusing our slyyglasses on our human neighbors that it seems an easy matter to label them and their affairs, but when it comes to birds, - alas! not only are there legions of kinds, but, to our bewildered fancy, they look and sing and act exactly alike. Yet though our task seems hopeless at the outset, before we recognize the conjurer a new world of interest and beauty has opened before us.

The best way is the simplest. Begin with the commonest birds, and train your ears and eyes by pigeon-holing erery bird you see and every song you hear. Classify roughly at first, - the finer distinctions will easily be made later. Suppose, for instance, you are in the fields on a spring morning. Standing still a moment, you hear what sounds like a confusion of songs. You think you can never tell one from another, but by listening carefully you at once notice a lifference. Some are true songs, with a definite melndy, - and tune, if one may use that word, - like the song of several of the sparrows, with three high notes and a rum 
down the scale. Others are only monotonous trills, always the same two notes, varying only in length and intensity, such as that of the chipping bird, who makes one's ear's fairly ache as he sits in the sum and trills to himself, like a complacent prima donna. Then there is always plenty of gossiping going on, chippering and chattering that does not rise to the dignity of song, though it adds to the general jumble of sounds ; but this should be ignored at first, and only the loud songs listened for. When the trill and the elaborate song are once contrasted, other distinctions are easily made. The ear then catches the quality of songs. On the right the plaintive note of the meadowlark is heard. while out of the grass at the left comes the rollicking song of the bobolink.

Having begun sorting sounds. you naturally group sights, and so find yourself parceling out the birds by size and color. As the robin is a well-known bird, he serves as a convenient unit of measure - an ornithological foot. If you call anything from a humming-bird to a robin small, and from a rohin to a crow large. you have a practical division line. of use in getting your bearings. And the moment you give heed to colors, the birds will no longer look alike. To simplify matters, the bluebird. the oriole with his orange and black coat, the scarlet tanager with his flaming plumage, and all the other bright birds can be classed together: while the sparrows, fly- 
catchers, thrushes, and vireos may be thought of as the dull birds.

When the crudest part of the work is done, and your eye and ear naturally seize differences of size, color, and sound, the interesting part begins. You soon learn to associate the birds with fixed localities, and once knowing their favorite haunts, quickly find other clues to their ways of life.

By going among the birds, watching them closely, comparing them carefully, and writing down, while in the field, all the characteristics of every new bird seen, - its locality, size, color, details of marking, song, food, flight, eggs, nest, and habits, _ you will come easily and naturally to know the birds that are living about you. The first law of field work is exact obserution, but not only are you more likely to observe accurately if what you see is put in black and white, but you will find it much easier to identify the birds from your notes than from memory.

With these hints in mind, go to look for your friends. Carry a pocket note-book, and above all, take an opera or field glass with you. Its rapid aljustment may be troublesome at first, but it should be the "inseparable article" of a careful observer. If you begin work in spring, don't start out before seren o clock, hecause the confusion of the matins is discouraging - there is too much to see and hear. But go as soon as possible after breakfast, for the birds grow quiet and 
fly to the woods for their nooning earlier and earlier as the weather gets warmer.

You will not have to go far to find your first bird.

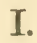

THE ROBIN.

Next to the crow, the robin is probably our best known bird; but as a few of his city friends have never had the good fortune to meet him, and as he is to be our " unit of measure," it behooves us to consider him well. He is, as every one knows, a domestic bird, with a marked bias for society. Everything about him bespeaks the self-respecting American citizen. He thinks it no liberty to dine in your front yard, or build his house in a crotch of your piazza, with the help of the string you have inadrertently left within reach. Accordingly, he fares well, and keeps fat on cherries and strawberries if the supply of fish-worms rums low. Mr. Robin has one nerrous mannerism - he jerks his tail briskly when excited. But he is not always looking for food as the woodpeckers appear to be, nor flitting about with nervous restlessness like the warblers, and has, on the whole, a calm, dignified air. With time to meditate when he chooses, like other sturdy, well-fed people, his reflections usually take a cheerful tum; and when he lapses into a. poetical mood, as he often rloes at sumise ancl 
sunset, sitting on a branch in the softened light and whispering a little song to himself, his sentiment is the wholesome every-day sort, with none of the sadness or longing of his cousins, the thrushes, but full of contented appreciation of the beautiful world he lives in.

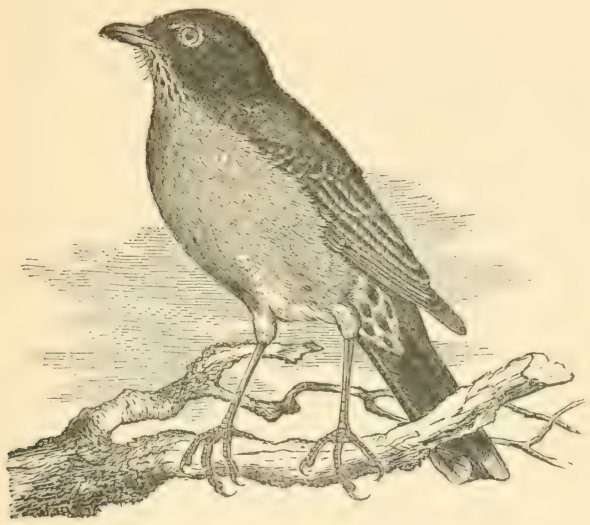

Unlike some of his human friends, his content does not check his activity. He is full of buoyant life. He may always be heard piping up above the rest of the daybreak chorus, and I have seen him sit on top of a stub in a storm when it seemed as if the harder it rained the louder and more jubilantly he sang. He has plenty of pluck and industry, too, for every season he dutifully accepts the burden of seeing three or four broods of bird children through all the danger's of cats, hawks. 
and first flights; keeping successive nestfuls of gaping mouths supplied with worms all the summer through.

His red breast is a myth and belong's to his English namesake; and it must be owned that his is a homely reddish brown that looks red only when the sunlight falls on it. His wife's breast is even less red than his - in fact, she looks as if the rain had washed off most of her color. But, perhaps, had they been beautiful they would have heen vain, and then, alas for the robins we know and love now. When the children make their debut, they are more strikingly homely than their parents : possibly because we have known the old birds until, like some of our dearest friends, their plainness has become beautiful to us. In any case, the eminently speckled young gentlemen that come out with their new tight-fitting suits and awkward ways do not meet their father"s share of favor.

Perhaps the nest they come from accounts for their lack of polish. It is compact and strong, built to last, and to keep out the rain; but with no thought of beauty. In building their houses the robins do not follow one plan, but begin with the frame and work in. When the twigs and weed stems are securely placed they put on the plaster - a thick layer of mud that the bird moulds with her hreast till it is as hard and smooth as a plaster cast. And inside of all, for cleanliness and comfort, they lay a soft lining of 
dried grass. This is the typical nest, but of course, there are marked variations from it. Usually it is firmly fixed in the crotch of a branch or close to the body of the tree where its weight can be supported.

But who does not know instances of oddly placed nests outside of trees? The "American Naturalist" records one "on the top of a long" pole, which stood without support in an open barnyard," and Audubon notes one within a few feet of a blacksmith's anvil. A number of interesting sites have come within my notice. Among them are: the top of a blind; an eave trough; a shingle that projected orer the immer edge of an open shed; and, most sing'ular of all, one inside a milk-house, set precariously on the rim of a barrel that lay on its side, just above the heads of the men who not only appeared both night and morning with alarmingly big milk pails, but made din enough in plying a rattling (reaky pump) handle to have sent any ordinary bird bolting through the window.

Robins usually nest comparatively high, though Audubon tells of a nest found on a bare rock on the ground, and this summer I found one in the crotch of a small tree only two and a half feet from the earth. It was near a hen yard, so perhaps Madam Roloin was following the fashion by laying her egg's near the ground. In any case. she was on risiting terms with the hen-roost. for, singularly enough, there were feathers platsteresl 
about the adoloe wall, though none inside. Perhaps the weather was too warm for a feather bed: - or was this frivolous lady bird thinking so much of fashion and adormment she could spare no time on homely comfort?

Longfellow says :

"There are no birds in last year's nest,"

but on a brace in an old cow shed I know of, there is a robin's nest that has been used for sereral years. A layer of new material has been added to the old structure each time, so that it is now eight inches high and bids fair soon to rival the fourteen story flat houses of New York. A remarkable case is given in the "Naturalist" of a robin that had no " bump of locality," and distributer its huilding material impartially over nearly thirty feet of the outer cornice of a house.

You may look for rohins almost anywhere, but they usually prefer dry open lamd, or the edge of woodland, being averse to the secluded life of their relatives, the thrushes, who build in the forest. Those I find in the edge of the woods are much shyer than those living about the house, probably from the same reason that robins and other's of our most friendly Eastern birds are wild and suspicious in the uninhabited districts of the West-or, who will say there are no recluses among birds as well as men?

The flight and song of the robin are characteristic. The flight is rappid, rlear cont, and straight. 
Unlike many birds, he moves as if he were going somewhere. His voice is a strong clear treble, loud and cheerful, but he is not a musician, and has no one set song. His commonest call has two parts, each of three notes run together; the first with a rising, the last with a falling inflection, like, tril-la-ree, tril-la-rah ; tril-la-ree, tril-la-rah. But he has a number of calls, and you must be familiar with the peculiar treble quality of his note to avoid confusing it with others.

In the fall, Lowell says,

"The sobered robin hunger-silent now,

Seeks cedar-berries blue, his autumm cheer,"

and this "sobered" suggests a question. Why is it that as soon as robins form flocks, they become shy? Is it because they are more often shot at when migrating in large numbers; or because, as Mr. William Hubbell Fisher suggests, they have left their homes, and so have lost confidence in the surroundings and people?

In some localities they live on cerlar-berries in the fall, but here they are well satisfied with mountain ash berries, wild cherries, and ungathered crab apples. Speaking of their food, what a pity that angler's cannot contract with them for a supply of bait! Woe betide the fish-worm that stirs the grass on the lawn within their hearing! How wise they look as they cock their heads on one side and stand, erect and motionless, peering down on the ground. And what a smprise it 
must be to the poor worm when they suddenly tip forward, give a few rapid hops, and diving into the grass drag him out of his retreat. Though they run from a chicken, robins will chase chipmunks and fight with red squirrels in defense of their nests or young.

\section{II.}

THE CROW.

The despised crow is one of our most interesting birds. His call is like the smell of the brown furrows in spring - life is more sound and wholesome for it. Though the crow has no song, what a variety of notes and tones he can boast! In vocabulary, he is a very Shakespeare among birds. Listening to a family of Frenchmen, though you do not know a word of French, you easily guess the temper and drift of their talk, and so it is in listening to crows - tone, inflection, gesture, all betray their secrets. One morning last October I caught, in this way, a spicy chapter in crow family discipline.

I was standing in a meadow of rich aftermath lying between a stony pasture and a small piece of woods, when a young crow flew over my hear. cawing softly to himself. He flew straight west toward the pasture for sereral seconds, and then, as if an idea had come to him, turned his head 
and neck aromd in the intelligent "row fashion, circled back to the woods, lit, and cawed vociferously to three other crows till they came over across the pasture.

After making them all circle over my hear, perhaps merely as a blind, he took them lack to his perch where he wanterl them to go beechnutting - or something else. Whaterer it was, they evidently scomed his childishness, for they flew back to their tree across the field as fast as they had come. This put him in a pet, and he would not budge, but sat there sputtering like a spoiled child. To everything he said, whether in a complaining or teasing tone, the same gruff paternal caw came back from the pasture. "Come along!" it seemed to say. To this the refractory son would respond, "I won't." They kept it up for several minutes, but at last paternal authority conquered, and the big boy, making a wirle detour. flew slowly and reluctantly back to his family. He lit on a low branch under them, and when the father gave a gruft "I should think it was time you came," he defiantly shook his tail and cleaned his bill. After a few moments he condescerided to make a low half sullen, half sublued remark, but when the family all started off again he sat and sorended some time hefore he would follow them, and I suspect he compromised matters then only because he rid not want to be left behinel.

The "intelligence of the "iow" has hecome a 
platiturle. hut when we hear of his cracking clams by dropjung them on a fence, coming to roost with the hens in cold weather, and - in the case of a tame crow - opening a door by lighting on the latch, his originality is a surprise. A family near here had much merriment over the gambols of a pet crow named Jim. Whenerer he saw the gardener passing to and fro betwe'n the house and garden, he would fly down from the trees. light on his hat, and ride lack and forth. He liked to pick the bright blossoms, particularly pansies and scarlet geraninms, and would not only steal hright colored worsteds and ribbons, but tear all the yellow covers from any novels he came across. When any one went to the regetable garden he showed the most commendahle eagerness to help with the work, being anxious to pick whaterer was wanted - from rasplorries and currants to the little eucumbers gathered for pickling.

The sight of the big black puppy waddling along wagging high in air a long black tail incongruously finished off with a tipping of white hairs was too much for . Tim s soluriety. Down he would dive, give a nip) at the hairs.and be gravely seated on a buanch just out of reach by the time Brumo had tumed to snap at him. Let the puplyy move on a step, and down the mischief would come again, and so the two would play - sometimes for more than half an hour at a time. Then again, the joke would take a more practical turn, for, in- 
stead of flying overhead when Bruno looked back, Jim would steal the bone the puppy had been gnawing.

The erow was happy as long as any one would play with him, and never tired of flying low over the ground with a string dangling from his bill for the children to run after. Another favorite play was to hold on to a string or small stick with his bill while some one lifted him up by it, as a baby is tossed by its arms. He would even hold on and let you "swing him around your head." He was never daunted, and when the toddling two-year. old would get too rough in her play and strike at him with her stick, he would either catch the hem of her pinafore and hold on till she ran away, or. would try scaring her, rushing at her - his big black wings spread out and his bill wide open.

One day his pluck was thoroughly tested. Hearing loud caws of distress coming from the lawn, the gardener rushed across and found Jim lying on his back, his claw tightly gripping the end of one of the wings of a large hawk, that, surprised and terrified by this turn of the tables was struggling frantically to get away. Jim hele him as tight as a vise, and only loosened his grasp to give his enemy into the gardener's hands. After letting go he submitted to the victor's reward, letting his wounds be examined and his bravery extolled while he was carried about - wearing a most consciously heroic air, it must be confessed - for due celebration of the victory. 


\section{III.}

\section{THE BLUEBIRD.}

As you stroll through the meadows on a May morning, drinking in the spring air and sunshine, and delighting in the color of the dandelions and the big bunches of blue violets that dot the grass, a bird call comes quavering overhead that seems the voice of all country loveliness. Simple, sweet, and fresh as the spirit of the meadows, with a tinge of forest richness in the plaintive tru-al-ly that marks the rhythm of our bluebird's undulating flight, wherever the song is heard, from eity street or bircl-box, it must bring pictures of flowering fields, blue skies, and the freedom of the wandering summer winds.

Look at the bluebird now as he goes over your head - note the cimnamon of his breast; and as he flies down and turns quickly to light on the fence post, see the cobalt-blue that flashes from his back. These colors are the poet's signs that the bird's sponsor's are the "earth and sky." And the little creature has a wavering way of lifting' its wing's when perching, as if hesitating between earth and sky, that may well carry out the poet's hint of his wild ethereal spirit.

Notice the bluebird's place in literature. The robin, with his cheerful soprano call, serves as the emhlem of domestic peace and homely cheer ; but 
the bluebird, with his plaintive contralto warlole, stirs the imagination, and is used as the poetic symbol of spring. The temper of the bluebird makes him a fit subject for the poet's enconiums. Mr. Burroughs goes so far as to say that "the expression of his indignation is nearly as musical as his song."

Lowell speaks of the bluebird as

\section{"shifting his light load of song}

From post to post along the cheerless fence."

But although he is as restless and preocenpied here as elsewhere, lifting his wing's tremulously as if in reality "shifting his load of song," and longing to fly away, the bluebird sometimes comes down to the prose of life even here and actually hides his nest in the hole of a fence rail. When this is not his fancy he fits up an old woodpecker's hole in a post, stub, or tree; or, if more social in his habits, builds in knot-holes in the sides of barns, or in bird-boxes arranged for his use. At Northampton I was shown a nest in an old stuh by the sicle of the road, so shallow that the father and mother hirds fed their young from the outside, clinging to the sides of the hole and reaching in to drop the food into the open mouths below.

Although the bluebird has such a model temper, it has not always a clear iclea of the laws of meum and tuum, as was shown by a nest found directly on top of a poor swallow's nest where there lay four fresh eggs: The nest is usually lined with 
dry grasses and similar materials. The eggs, from four to seven in number, are generally plain pale greenish blue, but occasionally white.

Sitting on a fence at a little distance the young birds look almost black, but as they fly off you catch a tinge of blue on their wings and tails. Their mother is more like her husband, but, as with most lady birds, her tints are subdued doubtless the result of "adaptation," as bright color's on the back of the brooding mother would attract danger.

We have two reasons for gratitude to the bluebird. It comes home early in the spring, and is among the last to leave in the fall, its sweet note trembling on the air when the "bare branches of the trees are rattling in the wind."

\section{IV.}

CHIMNEY SWIFT; CHIMNEY "SWALLOW."

WI.ITCI a chimney swift as he comes near you. rowing through the air first with one wing and then the other, or else cruising along with sails set. Look at him carefully and you will see that he is not a swallow, although he often goes by that name. He looks much more like a bat. His outlines are so clear cut and angular that he could be reduced, roughly, to two triangles, their common base cutting his body vertically in halves. 
His tail is, of itself, an acute-angled triangle terminating merely in bristles; and his wings look as if made of skin stretched on a frame, bat fashion, instead of being of feathers.

He twitters in a sharp chippering way as he flutters through the air and picks up flies, saying, as Mr. Burroughs puts it, "chippy-chippy-chirio, not a man in Dario can catch a chippy-chippychirio." And you are inclined to believe the bnast - such zigzag darting, such circling and rumning: The men of Dario would need seven league wings to keep up with him, and then, after a lightning race, when just ready to throw their pinch of salt, with a sucklen wheel the chippychirio would dart down a chimney and disappear from sight.

And what a noise these swifts do make in the chimmeys! If you ever had a room beside one of their lodging-houses you can testify to their " nocturnal habits during the nesting season." Such chattering and jabbering, such rushing in and scrambling out! If you only could get your spyglass inside the chimney! Their curious little nests are glued against the silles like tiny wall pockets; and there the swifts roost, or rather hang, clinging to the wall, sicle by sicle, like little sooty bats. Audubon says that before the young birds are strong enough to fly they clamber up to the mouths of the chimmeys as the pitifully triumphant chimney-sweeps used to come ul for a 
breath and wave their brooms in the air at their escape from the dangers below. Though never venturing near us the swifts come to live inside om houses. Like the robin they are citizens, but what a contrast!

Their feet are weak from disuse, and it is believed that they never light anywhere except in a chimney or in a hollow tree, where they sometimes go at night and in bad weather. They gather the twig's they glue together for their nests while on the wing, and their ingenuity in doing it shows how averse they are to lighting. Audubon says: "The chimmey swallows are seen in great numbers whirling around the tops of some decayed or dead tree, as if in pursuit of their insect prey. Their movements at this time are exceedingly rapid; they throw their body suddenly against the twig, grapple it with their feet, and by an instantaneous jerk snap it off short, and proceed with it to the place intended for the nest."

\section{V.}

CATBIRD.

Hign trees have an monsocial aspect, and so, as Lowell says, "The eatbird croons in the lilacbush." in the alders, in a prickly ash copse, a barberry-bush, or by the side of the garden. In Northanpton one of his farrorite hames is an old 
orchard that slopes down to the edge of Mill River. Here he is welcomed every year by his college girl friends; and in the open seclusion of an apple-tree proceeds to build his nest and raise his little family, singing through it all with keen enjoyment of the warm sunshine and his own company.

To the tyro the catbird is at once the most interesting and most exasperating of birds. Like some people, he seems to give up his time to the pleasure of hearing himself talk. A first cousin of the mocking-bird - whom he resembles in person much more than in voice - perhaps the relationship accounts for his overweening confidence in his rocal powers. As a matter of fact his jerky utterance is so harsh that it has been aptly termed asthmatic.

The catbird is ummistakably a Bohemian. He is exquisitely formed, and has a beantiful slategray coat, set off by his black head and tail. By nature he is peculiarly graceful, and when he chooses can pass for the most polished of the Philistine aristocracy. But he cares nothing for all this. With lazy self-indulgence he sits by the hour with relaxed muscles, and listlessly drooping wings and tail. If he were a man you feel confident that he would sit in shirt sleeves at home and go on the street without a collint.

And his oceupation? His cousin is an artist, lut he — is he a wag as well as a caricaturist, or 
is he in sober earnest when he tries to mimic the inimitable Wilson's thrush? If a wag he is a success, for he deceives the unguarded into believing him a robin, a cat, and — "a bird new to science!" How he must chuckle over the enthusiasm which hails his various notes and the bewilderment and chagrin that come to the diligent observer who finally catches a glimpse of the garrulous mimic!

The catbird builds his nest as he does everything else. The loose mass of coarse twig's patched up with pieces of newspaper or anything he happens to fancy, looks as if it would hardly bear his weight. He lines it, howerer, with fine bits of brown and black roots, and when the beautiful dark green eggs are laid in it, you feel sure that such an artistic looking bird must enjoy the contrasting colors.

\section{VI.}

KEEL-TAILED BLACKBIRD ; CROW BLACKBIRD; BRONZED GRACKLE.

Lowlut gives this bird the first place in the calendar. He says :-

"Fust come the blacklirds clatt'rin' in tall trees,

And settlin' things in windy Congresses, -

Queer politicians, though, for I'll be skinned

If all on 'em don't head against the wind."

In spite of all that may be brought up in Grand 
Jury against these "queer politicians," who is there that ('ould not (onfess to a thrill of pleasure when they appear about the house ' clatt'rin' in tall trees"?

As Mr. Burroughs has it: "' The air is fillerl with cracking, splintering, spurting, semi-musical sounds, which are like pepler and salt to the ear." There is a delicions reality to thein notes. Tre feel now that spring is not a myth of the poets. after all, but that she has sent this blatek arlvance guard as a promise of wild Hower's and May-day.

Black, did I say? Nothing could be more misleading. Mr. Ridgway descolibes the body of the purple grackle as " hrassy olive or hromze," his neck as "steel-blue, violet, purple, or lorassy green," and his wings and tail as " purplish or violet-purplish." He is one of the most brilliant of our bird beanties. Watch him as he ambles over the branches, and when the sumlight strikes. him you will wonder who could have heen so blind as to duh him blackbird. Call him, rather, the black opal!

He is a bird of many accomplishments. To begin with, he does not condescenrl to hop), like ordinary birds, but imitates the crow in his stately walk; then he has a steering applaratus that the small boy might well study in coasting time. He can turn his tail into a rudcler. Watch him as he flies. While he is going struight ahear you do not notice anything unusual, but as soon as he 
turns or wants to alight you see his tail change from the horizontal to the vertical - into a rudder. He is called keel-tailed on account of it.

Moreover, he can pick beechnuts, catch crayfish without getting nipped, and fish for mimnows alongside of any ten-year-old. Last October I foumd him beech-nutting, but he made hard work of it. I suspect the cold snap - for there was snow on the gromul - had stiffened his toes so that he was more awkward than usual. Poor fellow, I felt sorry for him, it entailed such dangerous gymmastics! But it was amusing to see him walk over the branches, stretch his neck to the point of dislocation, and then make such a determined dive after the nut that he nearly lost his balance, and could only save himself by a desperate jerk of the tail. Even when he picked out a nut he had to put it under his claw and drill through the shell, pick-axe style, hefore he could get a morsel to eat. He evidently thought it rather serious sport, and flew down for some shriveled crab-apples as a second course. But an army of robins had possession of the apple-tree and two of them were detailed to drive him off, so he harl to finish his breakfast up in the cold beech top.

A long list of nesting sites might be given, inchuling martin-houses. poplars, evergreens, holes in stuls, the sides of fish hawk's nests, and church spires where the blatchbirds" "rlatt'rin" is 
drowned by the tolling bells. Instances of their quarrels with rolins and other lirds would fill a volume, but the most interesting feut of which I have heard was enacted in the garden of the keen observer and botanist, Mrs. Helen M. Bagg, and its progress was watched by her umnoticer, as she looked out upon the participants from among the flowering shrubs and vines that surround her cottage. I quote her racy description :

- Early one May two rolins, with many manifestations of happiness, set up house-kereping in a tree near the south end of my honse. A few days later a large flock of blackbirds alighted on the trees on the north side of the vard. There had been a blackloird wedling, and their friends had escorted them hither with the laudable intention of fincling a suitable location for a nest for the happy pair. A loud chattering and fluttering followed, one adrising this place, another that. At length the young husband espied the broat top of the water-pipe, under the eares, and settled on that as a most secure and suitable home for his bride. The wedling gruests, with the satisfaction that comes from the conscionsness of having performed one's duty, took their departure. leaving the blissful ('ouple to the uninterrupted enjoyment of their own society. Ah ! who conld have forestold 'on night so fair', such awful morn' could rise?" 
"In the mean time the rolins had heen watching these musual proceedings with much anxiety and measiness; apparently not well pleased and not a little alarmed that their hereditary foes should presume to invade their domains and become domiciled in such close proximity to their own residence. But they made no hostile demonstrations that day, waiting to see the turn of affairs, and, as the sequel shows, to gain time to summon the assistance of friends. Early the next morning they resolved to eject the new-comers from the premises.

"Then occurred the inost remarkable scene I ever witnessed. At the loud cries of the combatants an immense number of birds of both kinds came flocking from all quarters to the scene of action. as if they had heen expecting the affray. They attacked each other with great ferocity and fonght pluckily with hills and feet amid loud rries of anger and derision. Feathers flew. The wounded would fy away to a neighboring tree to nurse their hurts for a moment, when, still smarting with pain, back they would come to fight with redombled fury. The shrieks and cries increased till it seemed a reritalle pandemonium. Every rolin and hlacklnirel within the radius of a mile must have heen present, either as spectator or participant in the strife. Ifter a time, finding that both parties were equally brave, and that neither would yield, they with one alcord withlew from 
the conflict as suddenly as they came, a few only remaining to arbitrate matters.

- The path from the house to the road divides the yard into equal parts. It was agreed that in future the blackbirds should keep on the north side, and the robins on the south side of this path. Peace and quiet reigned the rest of the day, all parties being too exhausted to resume the struggle even if they had not been in homor bound to respect the treaty. But do not fancy that the feud was forgotten. By no means. The sleek black'oated, dapper young' gentleman, conscious of having won the victory, inasmuch as he had not been dislodged from his position, allowed no opportunity to pass in which he might show his contempt for or exult over his plainly-dressed and comparatively inelegant neighbors.

" When the nest-building commenced, our gay chevalier complacently pormitted his meek little wife to perform the main part of the labor, while he would perch himself on a limb as near the dividing line ats possible and taunt or ridicule his opponents, whom family cares alone prevented from reciprocating the complinents - the will and desire were strong enongh. Sometimes he would examine the nest to see how the work progressed, and oceasionally he condescenderl to pick up a straw and fly with it to a tree near by and sit there with it in his month with a wonderfully self-satisfied air, yet nerer offering it to his mate. 
After a few moments he would drop it, smooth his plumage, wheel about, whisk his tail, and perform various other anties for the delectation of Mrs. Blackbird; then he would suddenly dart off to see what the robins were about.

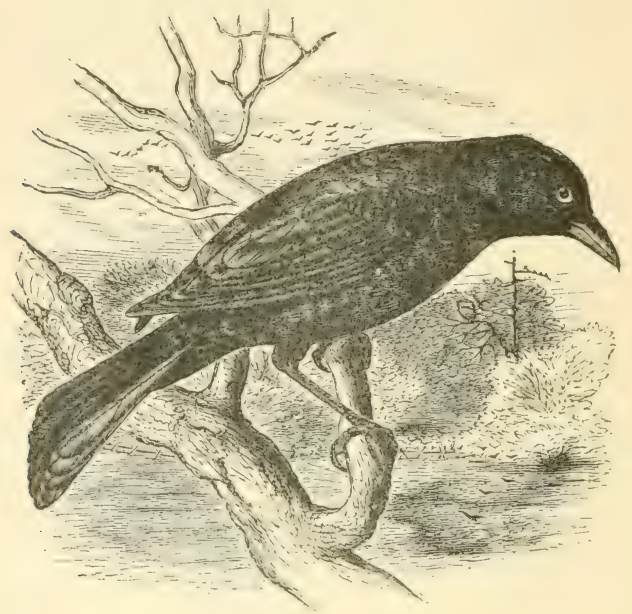

"During the weeks that followed, through nestmaking and incubation, the enmity between the blacklirds and rolins never abated. They were ever wary and on the alert, and if it chanced that either party, returning to his home, happened to ('ross the 'Mason and Dixon's line," the other was out of his nest in a trice to clrive off the intruder. Sometimes I thought both parties courterl these oceasions, though they would generally content 
themselves with angry words and looks.s. The next year they, or their children, returned, and each took amicable possession of his old nesting-place, neither deigning to notice his neighbor."

\section{VII.}

BOBOLINK; REED-BIRD; RICE-BIRD.

Though the bluebird brings the poet pictures of fields blooming with dandelions and blue violets, and visions of all the freshmess and beauty of nature, it tinges his thought with the tremulous sadness and longing of spring; but Rolert o' Lincoln, the light-hearted laughe: of June, bring's him the spirit of the long loright clays when the sun streams full upon mearlows glistening with buttereups and daisies.

Pray, have you seen the merry minstrel singing over the fields, or sitting atilt of a grass stem? And do you know what an orkl dress he masquelades in? If not, let me warn you. One day at college some young observer's came to me in great excitement. They har seen a new bird. It was a marvelous, unheard-of creature - its back was white and its hreast black. What "ould it he" Later on, when we were out one day, a bobolink flew on to the (ampus. That was their hird. And to justify their description they exclaimed, "II" looks as if his clothes were turned around." And so he does. 
Shades of short hair and 1)loomers, what an innovation! How the birds must gossip)! Instead of the light-colored shirt and rest and decorous dark coat sanctioned by the Worth of conven.

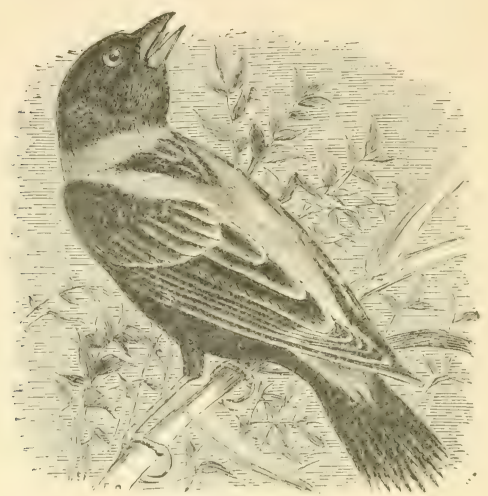

tional bird circles for centuries, this radical decks himself out in a jet-black shirt and rest, with not so much as a white collar to redleem him: besides having all of four almost white patches on the back of his coat! But don therate him - who knows hut this unique coloring is due to a process umecognized by the Parisian Worth, but designated hy Mr. Darwin as "alaptation"? Most field birds are protected by sparrowy backs, and with his black back, the tendency certainly seems to be to lessen the striking effect with lighter colors, leaving the breast, which is mseen when he 
is on the grass, as black as may be. In the fall when flying into danger's that necessitate an inconspicuous suit, the bobolink makes amends for the confusion caused in the spring, by allopting the uniform ochraceous tints of his wife. In this dress he joins large companies of his hrother's and flies south, where he is known first as the "reedbird," and then, in the rice-fields, as the "ricebird."

What could resemble the old time " needle in the hay-stack" more than a bobolink's nest in a meadow full of high gralss? But, dis you say, the birds act as a magnet to discover it? That seems to remove all difficulties. But suppose your magnet were bound to make you believe north, south, and east, west? When the bobolinks assure you their nest is - anywhere except where it is within a radius of five or six rods, you - well, try it some warm day next summer! Here is a bit of my experience.

One day in June I think I have surely found at bobolink's nest. Everything is simplified. Instead of a dozen pairs of birds flying up helter. skelter from all parts of the fold, there is only one pair, and they limdly give me a line across the meadow ending with a small elm on the west, and a fence on the east. As they only occasionally diverge to an evergreen on the north or go for a run to a distant field on the south, I $\mathrm{cm}$ confident. In imagination I am already examin- 
ing the brownish white, deeply speckled egg's and noting the details of the nest. But the best way is to keep perfectly still and let the birds show me just where the nest is, though of course it is only a matter of a few minutes more or less. I sit down in the grass, pull the timothy stems over my dress, make myself look as much as possible like a meatlow, and keep one eye on the bobolinks, while appearing to be absorbed with an olject on the other side. But they are better actors than I.

Tritter-itter-itter the anxious mother reiterates in a high key as she hovers suggestively over a tuft of grass a few rods away. So soon: My impatience can hardly be restrained. But - the father is coming.

Linglium-linglium-7inglium, he vociferates loudly, hovering over a bunch of weeds in just the opposite direction. By this time the mother is atilt of another timothy stem in a new place, looking as if just ready to fly down to her nest. And so they keep it up. I examine all the weeds and tussocks of grass they point out. On nearing one of them, the mother Hies about my head with a show of the greatest alarm; my hopes reach certainty - there is nothing there! I look under every notling buttereup and spreading daisy for yards around only to see Mrs. Robert of Lincoln hovering above a spot she had aroided before. The next clay I offer a reward to two children if they will find the nest, but the birds probably 
practice the same wiles on them - they can risrover nothing. What a pity the poor hirds can't tell friends from enemies. They treat me as if I were a brigand; but if they knew I wanted to peep at their pretty eggs and arlmire their housekeeping arrangements, how gladly they would show me about!

After noticing the clear cut, direct flight of the robin, the undulating flight of the bluebird, and the circling and zigzagging of the swift, you will study with interest the labored sallies and eccentricities of the bobolink. When he soars, he turns his wings down till he looks like an open umbrella; and when getting rearly to light in the grass puts them up sail fashion, so that the umbrella seems to be turned inside out. Incleed, from the skillful way he uses his wings and tail to steer and balance himself, you might think he had been trained for an acrobat.

The most animated song of the lobolink is given on the wing, although he sing's constantly in the grass, and on low trees and bushes. The most exuberantly happy of all our hirds, he seems to contain the essence of summer joy and sumshine. "Bobolintium-linkum-derih-deriti-deah" he warbles away, the notes fairly tumbling orer each other as they pour out of his throat. $\mathrm{U}_{\mathrm{p}}^{\mathrm{p}}$ from the midst of the buttercups and daisies he starts and flies along a little way, singing this joyous song with such light-hearted ferror that he is 
glad to sink down on the stem of some sturdy young timothy before giving his last burst of song.

Thoreau gives the best description I have ever seen of the first notes of the bobolink's song. He says: "I hear the note of a bobolink concealed in the top of an apple-tree behind me. . . . He is just touching the strings of his theorbo, his glassirhord, his water organ, and one or two notes globe themselves and fall in liquid bubbles from his tuning throat. It is as if he touched his harp within a vase of liquid melody, and when he lifterl it out the notes fell like bubbles from the trembling strings. Methinks they are the most liquidly sweet and melodious sounds I ever heard."

Almost every one gives a different rendering of the bobolink's meaning. The little German children playing in our meadows cry after him in merry minicry, "Oncle-dey duntiel-dey oncle-de! clunliel-de!." The farm boy calls him the "cornplanting bird," and thinks he says, "Dig a hole, dig a hole. put it in. put it in, cover't up, cover 't up, stamp on 't, stamp) on 't, step along."

\section{VIII.}

RUFFED GROUSE; PARTRIDGE.

THE partridge, or ruffed grouse as he is more properly called, is our first true woods bird. His 
colors are the colors of the brown leaves that lie: on the ground, and as he crouches close to the: earth it is no easy task to discorer him. The one, thought of the poor persecuted bird seems to be to keep out of reach of his enemies.

Here, one of his favorite covers is in a quiet. spot where I go to gather ferns - a grove that "fronts the rising sun" and is full of dappled maple sapling's interspersed with the white birches that gleam in the morning light and keep birchbark scrolls rolled up along their sides ready for the birds to carry away for their nests. At the foot of the treeri, and close to the moss-covered drumming-log, ferns stand in pretty groups of all growths from the tiny green sprays and the soft uncurling downy balls to the full grown arching fronds whose hacks are dotted with brown fruit; while, as a protecting herlge along the front of the grove, great masses of the tender green mountain ferm give their delicate fragrance to the air. But pass by this hiding place, and a sudden $n \cdot 7$ ir through the bushes, first from one startled bird and then another, tells you they have flown before you. Approach the drumming-log when the air has been resounding with exultant blows - the noise stops, not a bird is to be seen.

As we feed the partridges in our woods and never allow any hunting there, in winter the birds venture about the house for food. The Norway spruces by the garden afford a warm shelter, and 
there, under the boughs, corn is kept for them on barrels and boxess. On the other side of the house, in front of the dining-1room window, is a similar store for the blue jays and gray squirrels; and as they sometimes visit the pratridges' table, the latter often fly around the house to see if the squirrels corn tastes any better than theirs.

The first snowy morning they appear we have to peek through the shutter's very cautiously, for they are painfully shy, crouching in the snow, listening tremulously to the least sound from the house, looking abont every time they pick up a kernel of corn, and whirring off back to their evergreens if a window or blind chances to be thrown open. But they soon lose their fears, and some morning's we find their pretty footprints in the snow on the piazza.

One winter they seemed to show a fondness for music, often coming close to the house as I was playing the piano. Indeed they and the squirrels must both have followed the Pied Piper of Hamelin - the squirrels not only nibble their corn with complacent satisfaction when the music box is wound for them, but have eren let themselves be stroked when a peculiarly pathetic air was whistled! Who dare say what forest concerts the pretty creatures may get up on the long winter evenings when they are tired frolicking on the moonlit snow!

Still the partridges seem to like the hright red 
berries of the cranberry-tree even better than they do music, and we have been much amused watching their attempts to get the berries from a bush by the garden. Sometimes they stand in the snow underneath and jump for them ; but one day when the bush was covered with ide one adventurous bird flew up on a branch and nearly turned a somersault in trying to lean over and pick off the berries and at the same time keep hold of the slippery perch.

But our chief pleasure is in watching the partridges from the bay window of the dining-room. The young men are as proud as turkey-cocks of the handsome black ruff's for which they were dubbed "ruffed grouse," and when they strut before the ladies, raising their crests, erecting their spread tails, and puffing out the ruffs orer their shoulders they remind one forcibly of the lordly cock. In matter of fact they do belong to the same family, - that of the gallinareous birds, and many of their mannerisms betray the relationship. Their way of scratching in the snow, resting their weight on one foot and scratching with the other, is like that of the common hen, and their drumming is the finished performance that is caricatured by Chanticleer. Drumming with the partridge is a joy. He beats the air with his wings till it must needs sing for him, and the music is full of refreshing pictures of green mossy logs, arching ferns, and the cool shate of the woods. 


\section{IX.}

\section{RUBY-TIIROATED HUMIING-BIRD.}

DiD you ever see a humming-bird sitting on a bare branch of a towering tree? Until you have you will scarcely appreciate what a wee mite of a bird it is. Indeed I find it hard to think of it as a bird at all. It seems more like a fairy, "a glittering fragment of a rainbow," as Audubon calls it, or as some one else has said, -

"Like a gem or a blossom on pinions,"

something too dainty and airy to have even three inches of actual length. It seems like the winged spirit of color as it comes humming through the air to hover over the flower's on the piazza, its body like green beryl, and its throat glancing fire. Like Puck it might boast that it could "put a girdle round about the earth in forty minutes," for while we are wondering at its friendliness it darts off and is gone like the flash of a diamond.

In this vicinity the garden of Mrs. Bagg seems to be one of the farorite haunts of the hummingbirds, and she has kindly given me some notes on her experiences with them. She says:

"In confinement they do not appear to pine for" freedom, heating themselves against the wires like other birds, but seem contented and at home from the first I kept a pair caged a whole summer. 
feeding them with water sweetened with honey or sugar. When I put a ('up) of their food in the age they would alight on my fingers, and with their long flexible tongue suck oft the honey I had accidentally spilled. In disposition they are too pugnacious to live as harmoniously as one would expect or desire, sometimes pursuing one another around the cage with great ferocity, and such inconceivable rapidity that their tiny forms seemed resolved into absolute sound. I frecuently permitted them to fly about the room for exercise. but they never returned roluntarily to their cage. When caught they did not resist and struggle, but saw the door of their prisom-house closed upon them without a complaint. They had never a sick or unhapley day through the whole summer, but when the cold days of antumn approached they began to droop), although their cage was humg in the warmest place in the room. For three days they hung suspended to their perches hy their feet, and did not relax the hold while life lasterd. I have found them clinging to vines and shrubhery in that mammer on cold mornings after at frost, but thomgh seemingly lifeless the warmth of the hand would revive them.

"Some year's a few are unacoomintaly tarly" about migrating; at other times they make the mistake of coming too early in spring. Lncloultedly most of them migrate in August, but with them, as in every other community, there are al- 
ways some langards as well as bold pioneers. I once found one in my house on a very cold morning in the fall. He was probably sleeping on some house-plants that had been brought in from the frost the previous night, and was too benumbed with cold to know it. I caught and fed him, as it would have been barbarous to turn him out in the cold. He soon became a great pet, and was tame as a kitten.

"One day two gentlemen entered the room where his atge was hanging. both wearing tall hats. He fell immediately to the hottom of the (arge, with wings outspread, eyes closed, body rigid, and with every appearance of death. We took him in our hands and warmed him by the fire. He still remained motionless. We decided that those horts had frightened him to death. With a heary heart I laid him aside, intencling to embalm him at my leisure.

- A few minutes later my friends left the house. Directly after the door closed I heard a humming and buzzing in the room. Looking up, there was my hird circling around the room in the most hilarious mamner. Who (am tell whether his apparent death was not counterfeiterl? If it was not feigned, why dicl he revive the moment the door was closed and I was alone?

"If you capture one out of doors and hold him in your hand he will practice the same muse, stretching himself out, stiff and motionless. 
Thrown off your guard you stoop to examine your prize, when lo! your hand is empty and your birl nearly out of sight before you have time to recover from the astonishment.

"Towards the humble-lues he manifests the utmost ill-will, a veritahle · dog in the numger' spirit, driving him away from one flower after another till the bee in pure desperation turns on his persecutor. There are surely sweets enomgh for. all, and he knows it. Still it may he posisible that his animosity is aroused more hy a personal arersion he has to the bee than hy more selfish considerations. We will give him the benefit of the doubt. He is fond of silence, and will often sit half an hour together on a deasl twig wrapt in the profoundest meditation, and doulotless the incessant droning of the bees disturlss his reflections and irritates him beyond endurance. I had onces in my garden a ribhon-bed of white and rose colored Lamium. In its unsullied heauty it was like a dream of poetry. Erery flower was perfect with an unsurpassed and delicate loveliness. One sumny morning I olserved an unusual number of humming-birds and bees working anong the blossoms. Presently there was a commotion! The humming-birds had united to drive the bees away, darting at them furiously, uttering at the same time their spiteful, piping eries. 'The bees. intent on seeking their breakfast, at first gare up goorlnaturedly and flew to some other flower. only to 
be driven from that a moment later. At length forbearance ceased to be a virtue, and the temper of the apathetic bee was arouserl. A fierce battle ensued. They pursued one another around and around that flower bed, over and under and through the flowers, sometimes the birds and then the bees having the rantage. Their rage knew no bounds, and they fought till sheer exhaustion compelled them to desist. Every flower was torn to shreds, not a whole blossom remaining."

The nest of the humming-bird is as delicate as the little creature itself. It is built in the form of a small ('up), saddled upon a horizontal limb, and covered on the outside with lichens which make it look like a knol, on the branch. The child who discover's a humming-bird's nest is credited with sharp eyes.

\section{$\mathrm{X}$.}

MEADOW-LARK.

To many, the meadow-lark is only a voice, but if you follow the rule laid down at the beginning of your work, and are determined to see as well as hear, you will have little trouble in finding the owner of the plaintive ail that rises so mysteriously out of the grass.

Focus your glass on the meadow, and listen carefully for the dinection of the sound. As the 
lark is very much the color of the dead grass that covers the ground when he first comes north, and of the dry stubble left after the summer mowing, he is somewhat hard to see. When you have found him, it is a delightful surprise to see that

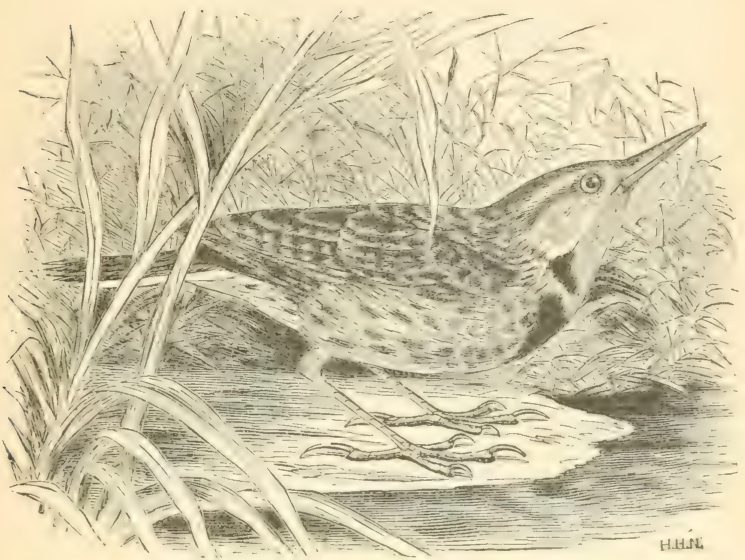

the brownish yellow disgune of his back is relieved, not, indeed, by a sable robe like the bobolink's, but by a throat of brilliant yellow, set off by a large black crescent.

The meatow-lark has two notable characteristics. Belonging to the blackbird family, he is a walker, and when he flies you will see that he is also one of the few birds marked by prominent white outer tail feathers. The peculiarities of his labored flight are exactily described by shelley 
when he says, in his Ode to the Skylark, "Thou dost flort and run." Flying seems hard work for. him, and he does as little of it as possible. When he starts up from the meadow, he goes in a direct line to the tree he wishes to reach. Like the bobolink, he nests in fields and lays his egg's in a coil of dried grass on the ground.

In variety and execution the famous song of the European lark may be superior to that of our own Eastern lark, though Wilson holds that ours excels it in "sweetness of voice." The mommful melody of the meatlow-lark is full of poetic suggestions; he is the hermit thrush of the meadows, and where the light-hearted bobolink's song jostles the sumbeams, he is as solitary and pensive as the lonely hermit when it thrills the hush of the sunset after-glow with its fervid Te Deum.

\section{XI.}

BL.ACK-CAPPED CHICKADEE; TITMOCSE.

READ Emerson's "Titmouse" and you will recognize this charming little bird without the aid of your glass. Not only in spring and fall. but in the coldest winter days you will hear what Thorean calls the "silver tinkling" chick-a-deedee-dee-dee, chircti-rt-der-dee-dee-dee ringing through the air. When you hear it, if you look earefully over the trees you will see a fluffy little borly 
dressed out in a black hood whose sombre tone is relieved by whitish side pieces, a vest to match the sides of the hood, and a dark gray coat for contrast. Clinging to the sicle of a tree one minute, and hanging upside down peceking at the moss on a branch the next, it is flitting aloout hither and thither so busily that unless you draw near you will hardly anteh a glimpse of its black (ap) and gray and white clothes. You need not fear scaring it, for it has the most winning' confidence in man, inspecting the trees in the front yard or those in the woods with the same trustful unconcern.

You are inclined to think that the busy chickadee takes no time to meditate, and sees only the bright side of life; and when you hear its plaintive minor whistle piereing the woods, you wonder if it can have come from the same little creature whose merry chirli-a-dee-dee yon lnnow so well. Thoreau calls this plaintive whistle the spring phobe's note of the chickarlee, and gives its winter call as day, day, dory. When haplyy, the chickadee is the best company one could hope for on a winter's walk; when busy it seems to realize perpetual motion; and when it gives up its ordinary pursuits and prepares to rear a family, it goes to work in the same whole-souled fashion. Leaving divilization with its many distrar.tions, it goes into the woods, and that is the last you see or hear of it until fall. Even there it is not con- 
tent to sit perched mp on top of an open nest, but builds in the side of a stump) or a dead stub, and retires from the world with the determination of a num.

You will wonder at first how such a tiny bill as the chickarlee's can be used as a pickaxe, but if you notice it carefully you will see that, without being clumsy, it is rery stout, for it is arched enough to give it strength. Of course the chickadee sometimes nests in natmal cavities in trees; and Auduhon says oll woodpectiers holes are occasionally used : hut most writers agree in thinking that it usually makes its own excavation, occasionally in comparatively hard wood.

One morning I was hurrying noisily through the underlorush of a clearing to get home in time for breakfast, when, suddenly, I came face to face with a pair of chicliadees. Even then they did not stir, but sat eying me calmly for several seconds. I suspected a nest, and when they had flown off, I discorered the opening in a decayed stul close by my side. The stub was a small one, being perhaps eight or teu inches in diameter and four and a half feet high. The entrance was about a foot from the top, and the nest itself a foot or more below this. What a tasteful little structure it was! Although out of sight, it was far prettier than most bird-houses on exhibition in the forest. Bits of fresh green moss gave it a dainty air, and brought out the dark gray of the 
squirrel or rabbit fur that made it snug and warm. I was tempted to wonder where the fur came from - had this innocent chickadtee tweaked it out of the back of some preocerupier animal? Perhaps the demure little recluse has a spice of wickedness after all, and its satisfaction in its secure retreat has something of exultant mischief in it!

In any case, it sometimes takes unfair adrantage, for this fall I saw a chickatee deliberately lying in wait for his breakfast, just as a spider would. I was patsing a Norway spouce when I caught sight of him pecking away on the unclev side of one of the lower branches. from he puiled out a large white chrysalis-like ball. Hew up on a branch and sat there till he disposed of it. Then he went back and hung himself, upsicle down, to the branch, just below the place where the first morsel had come from. Balderr, my hig Newfoundland, and I were within five fect of the little rogue, but he did not are for that. There he clung for as much as two or three minutes, perfectly motionless except when he turnerl his heard to give us a prexecoupied look. Then suldenly he picked down and drew ont a small white worm, and flew up into the brande with a triumphant little cry, as much as to say, "Ha, ha, I got you after all!" 


\section{XII.}

CUCKOO; RAIN CROW.

UnLess you follow the cuckoo to his haunts, you rarely see him. Now and then, perhaps, you catch a glimpse of his long brown body as he comes silently out of an orchard, an overgrown garden, or a clump of bushes, to disappear swiftly in a heavily leaved tree or mass of shrubbery where he suspects a fresh supply of insects.

A third longer than the robin, the cuckoo is a slender, olive-brown bird with a light breast. The two species are very similar in appearance and

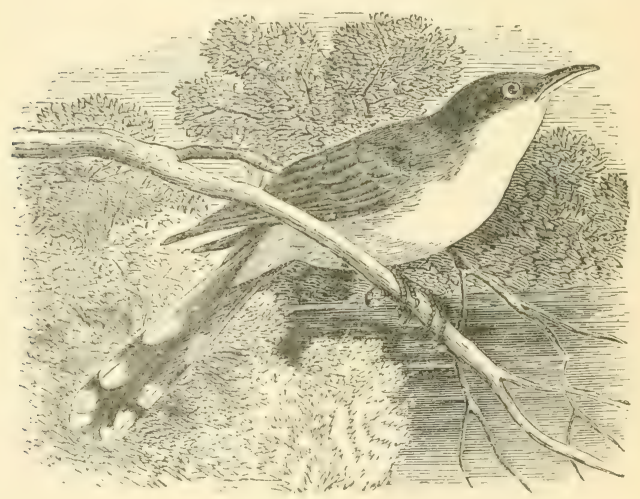

habit, but in the yellow-billed there are distinet white spots known as "thumb marks" on the 
under side of the tail. The black-hilled cuckoo is a plainer bird, its only striking peculiarity being its bright red eyelids.

You will do well to remember the rhythm of the cuckoo's notes. It may save you an experience I had one fall. I supposed the birds had left for the South, but hearing a regular liuk-7iuklink coming from the woods, and being especially anxious to study the cuclioo's habit., I left the raspberry patch where I was watching for rare warblers, and hurried off in search of the wandering voice. What a treat! - to he ahle to see a 'uckoo after all! I crept along with serupulous are, begrulging the time my aution cost me, but determined not to lose this last chance. What if he should Hy off before I could get there! But no - I began to exult - kink-7ink-7iul: came loud and clear as I stopped to listen for the direction of the sound. I must he almost up to him. Oh, that I could sweep) all the noisy dead leaves into the ditch! I look about anxiously for moss and old logs to step on. There! Grasping my notebook in one hand, with the other I laise my glass. A mischievous looking chipmmk, sitting erect on top of a mossy stump, suddenly jumps off into the leaves and - the sound stops ! 


\section{XIII.}

\section{YELLOW HAMMER ; FLICKER.}

Wrres people attempt to give their children descriptive names they generally meet with the success of the colored woman who christened her little girl "Lillie White" only to see her grow to he the darkest of her ebony family. But local bird names are more like nicknames; they usually tonch facts, not hopes, and hint the most striking features of coloring, song, flight, and habit. As you have discovered, this is true of the hluebird, chimmey swift, cathird, keel-t:iiled blacklbivel, humming-lind, and mearlow-lark : and looking over the yellow hammer's thirty-six common names given by Mr. Colburn in the Audubon Magazine for Jume, 1887, you will get a fair description of the bird. As he flies orer your head in the field your first impression is of a large yellow bird he is of the size of the crow hlarkbird - and on the list you find "yellow hammer," "yellow jay," and " pique-loois jame "; but as the yellow light comes mainly from his hright yellow shafts and the gold of the underside of his wings and tail, you have also "yellow-shafted woodpecker," and "golden-rvinged woodpecker." His dark lack and the lange white spot at the base of his tail. though conspicuous in flight, are not dignified by a name: but when he lights on the side 
of a tree or an old stul, you recognize him as a "woolpecker." With the help of your glass you also see the bright red crescent on the back of his head, for which he is probably called " crescent bird." There he clings, fastening his claws firmly in the bark, and bracing himself with the stiff quills of his tail, so that his convexity of outline almost amounts to a half circle as he bends forward to "hammer" "on the woorl. This is the best time to use your glass, for he is cuite a shy bird, and except when engaged in his favorite work, is hard to observe satisfactorily, even at a respectful distance. His dark back proves to be barred with black, and following him as he circles up the tree you get a glimpse of his loreast that discloses a large black collar separating his thickly spotted breast from the plain light throat.

The song of the yellow hammer is like the German th - he has n't any. He has a variety of cries and calls, however, and a trill that sounds like a great rattle shaken in the air. Mr. Colburn attributes trelve of his names to imitations of these various sounds: clape, (ave-duc, fiddler, flicker, hittock, hick-wall, ome-tuc, piute or peerit, wakeup, yaffle, yar'up, and yucker.

Mr. Ingersull refer's " flicker " to his flight, and if you watch your yellow hammer till he flies oft to another tree you will see that the adjective describes his peculiar hut characteristic woodpectker. flight better than the most labored description. 
50 BIRDS THROUGH AN OPERA-GLASS.

Mr. Colburn says he is called " tapjing bird" from it, because he looks as if "measuring off tape."

If you are persevering enough to follow him to his nest - and you never feel thoroughly acquainted with birds any more than with people

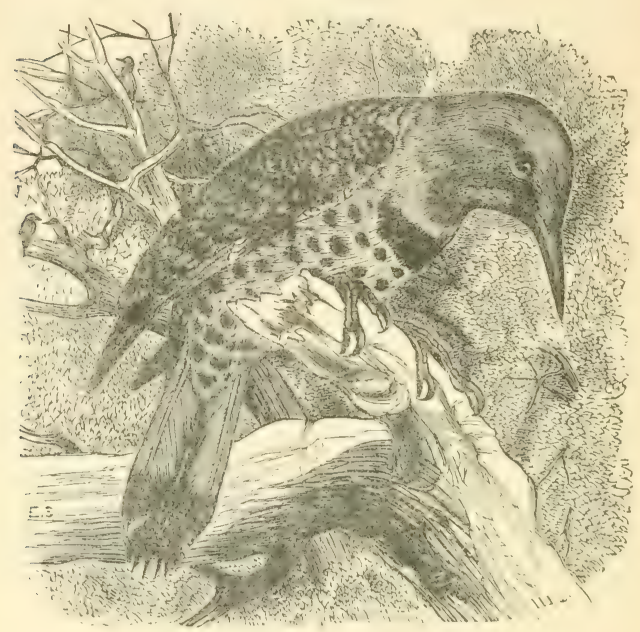

until you see them in their homes - you will disrover why he is alled " high-hold," "high-holder," and "high-hol" - that is, if the nest he has made is one of the high ones. Sometimes yellow hammers build rery low. IIowever this may be, the entrance to the nest is a large round hole, cut out of the wood of the trees, as the pile of chips on the ground attests. Inside, the hole is very 
deep and the white egons are laid on the chips at the bottom. The usual number of eggs is six.

A gentleman tells me a curious case of niscalculation on the part of a yellow hammer that built in an old apple-tree near his house. He says the old birkts liept hringing food to the nest so long that he thought something must be wrong, and went to investigate. The nest was just within his reach, and he fomd that, as he had supposed, the birds were more than large enough to fly. In far.t they were so large they could not get ont of the month of the nest, and were actually imprisoned there! The gentleman got an axe and rut out the opening for them, and the next morning the brood had flown.

Knowing the habits of the yellow hammer. you wonder why there is no name to credit him with the work he does for us in eating the boring ants that eviscerate on mollest trees; and you are still more surprised to find uo name to stamp him a field and gromel woolperelker, because his derotion to ant-hills and other gromel preserves is one of the characteristics that distinguish him from the other woodpectiers. Possibly the name "woodpecker lark" may refer to his custom of hunting. in the fields. 


\section{XIV.}

BALTIMORE ORIOI.E ; FIRE-BIRD; GOLDEN ROBIN :

HANG-NEST.

Wruson notices the interesting fact that our oriole was named by Limmæus in honor of Lord Baltimore, whose colors were black and orange.

He is shorter than the robin, and compared with that plump alderman is slenderly and delicately built - much more in the form of the blackbirds. His back is black instead of grayishbrown, and his breast orange instead of dull reddish. In habit, he contrasts still more strongly with the robin. Who ever saw Sir Baltimore watching for fish-worms in the grass, or taking possession of a crotch in the piazza? - and, on the other hand, who ever saw a robin hold his dinner under his claw and peck it to pieces as the orioles and their cousins the blackbirds do? The oriole is comparatively shy, and has a nervous, excitable temperament, while the robin is not only social but phlegmatic. Then the call of the firehird is shriller, and pitched on a higher key; while his love song is an elaborate poem in melody, compared with the blunt courtship of robin redbreast - just watch this graceful suitor some morning as he bows and scrapes before his ladylove to the rhythm of his exquisitely modulated song. Now rumning high and loud with joyful 
exultant love, then curving into a low, soft ('adence, vibrating with (aressing tenderness, it finally rounds off with hroken notes of entreaty so full of courtly devotion and sulmisision, yet, withal, so musical and earnest with tender love, that you feel sure his suit can never be denied.

When the oriole comes to build his nest and you compare his work with that of the rollin, you feel that you have an artistic (Queen Amme heside a rude mud hovel. The term hang-nest is strictly applicable. The birds are skillful weavers and build long, delicate, pocket-shaped nests that look as if made of gray moss. These they hang from the end of a branch, as if thinking of the first line of the old nursery rhyme, -

"When the wind blows the cradle will rock,

When the bough breaks the cradle will fall." -

and, indeed, the crarlles are built by such clever workmen that the bough must needs break to give them a fall. The nest looks as if it barely touched the twig's from which it hang's, but when you cxamine it you may find that the gray fibres have woven the wood in so securely that the nest would have to be torn in pieces before it conld be loosened from the twig's. What is the nest made of ? It shines as if woven with threats of gray silk, but it must be field silik from the stems of plants. And the horse hairs? Mr. Burroughs tells of one oriole who went bravely into the bark part of a horse stable for its hair lining. Sometimes a bit 
of twine or gay worsted thrown on the grass is glarlly aceepted, and Nuttall once saw an oriole carry off a piece of lampwick ten or twelve feet long.

In Northampton I witnessed an interesting case which proved that skill in nest making as well as other crafts comes by hard-earned experience, and, consequently; that manual tiaining should be introduced into all bird schools: A pair of young and inexperiencerl orioles fell in love and set out, with the assurance of most brides and grooms, to build a home for themselves. They surreseded alminaly in the selection of their building site, but them the trouls]e hegan. The premise that all young lovers are wearers or arehitects sometimes leads to dire syllogistic conchusions. $\mathrm{W}_{\text {as }}$ it the pressing husiness of the honeymoon that interfererl with the wearing. or was it be(anse this young (ouple had not yet learned how to pull together that their threads got in a snarl and their glaty pocket was all awry? Whatever the reason. the craclle was altogether too short to rock well, and was skewed up in such a fashion that some of the baby hirds would have heen sure of a smothering. Like Grimm is (dever Elsie the bircis foresaw all these dangers. and atctually left the completerl nest to be tosiced by the wind while they went off to try again in amother place. It is heliever to be musual for two young birds to pair together. 


\section{$\mathrm{XV}$.}

\section{BARN SIVALLOW.}

TuE harn swallow is the hamrlsomest and best known of the swallows. It is lustrous steel blut: above, and has a partial collar of the same between the deep chorolate of the rhin and throat and the pale chestmut of the hreast.

What a contrast to the noly so-ralled * ('himmey swallow " ! Ant not in coloring only. Compare its long forkerl tail with the short, spuare, hristly tail of the swift. And then wateh its Hightthe coursing of a Pegasins besicle the trotting of a racer! The swift hats womderful wing power, hut no gratee. It flies as if moler wager, and when hunting, its path might be marked off hy angles, for it zigzag's like a bat. But the ban swallow's coumse is all curves. It has the freest flight of any hird I have ever seen. It semes ahsolutely without effort or constraint.

The swallows are so agile they often dart down as you drive alonge the road, and rincle aromel and around you, managing dexterously to keep just ahear of the horses. At other times they run and cincle away orer the fields and through the sky, and at smonset often hament om rivers on lakes, skimming low over the surface and somertimes dipping down for a drink as they aro.

At rest, they sit side hy side on the ridge-pole 
of a barn or on a telegraph wire, where they look like rows of little mutes. It is funny enough to see them light on a wire. Fluttering over it for a moment before settling down, they sway back and forth till you are sure they must fall off.

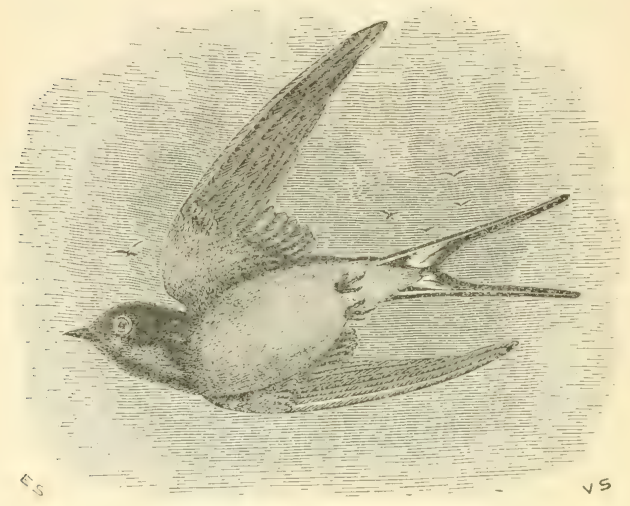

The roads afford them much ocempation. When not making statistics about the passers-lyy, or collecting mul for their nests, they take dust baths in the road. They usually build insicle barns or covered bridges. lining their nests with feather's, but a case is recorded of a nest under the eaves of a house, which was made entirely of " rootlets and grass," though thickly lined with downy chicken feathers. Мr. Burroughs tells of a barn nest "sardlled in the loop of a rope that was pendant from a peg in the peak." 
Of the notes of the barn swallow Mr. Bicknell says: "An almost universal misconception regards the swallows as a tribe of songless birds. But the barn swallow has as true claims to song as many species of long-established recognition as song birds. Its song is a low, chattering trill ... often terminating with a clear liquid note with an accent as of interrogation, not unlike one of the notes of the canary. This song is wholly distinct from the quick, double-syllabled note which so constantly escapes the bird during flight."

\section{XVI.}

\section{BELTED KINGFISHER.}

THe robin lives on neighborly terms in our dooryard, the swift secretes himself in our chimneys, the humming-bird hovers in our gardens, the barn swallow circles around our barns, the catbird talks to himself in our orchards, the oriole hangs his "hammock" from our elms, the bololink holds gay possession of our fields till the mower comes to dispute his claim, and the yellow hammer appoints himself inspector general of our ant-hills, fence-posts, and tree trumks: hut the kingfisher cares nothing for us or our halitations. He goes off by himself into the heart of the wilderness, not to 'rourh among' the brown leaves on the ground like the partridge, but to Hy high and 


\section{BIRDS THROUGH AN OPERA-GLASS.}

far over river and lake, "alling loudly to the echoes as he goes.

He is the most marked of the trillers, having a loud, rapid call that Wilson compares to a watchman's rattle, and that, as Mr. Burroughs ingen-

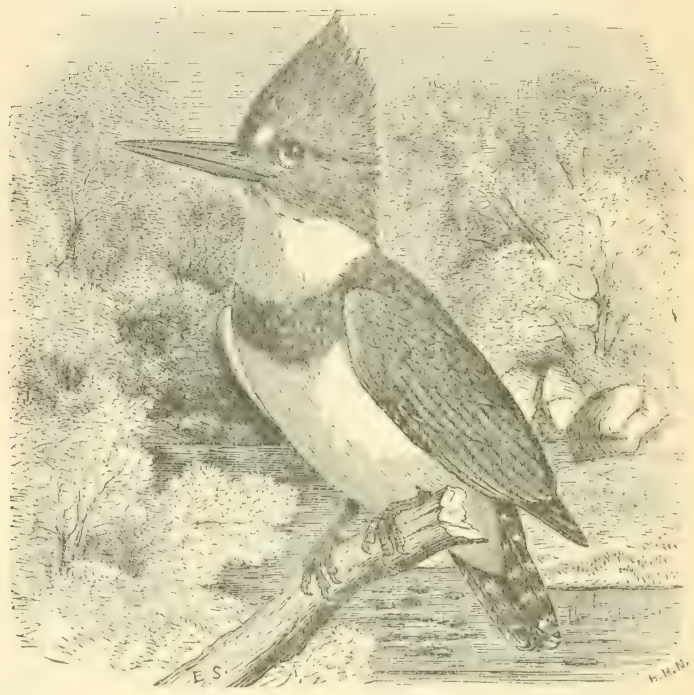

iously suggests, reminds you of an alamm clock. He usually gives it when on the wing, and if on hearing him you look up in time, you will see a large, ungainly slate-blue bird, with an odd flight - his short tail maling him out of proportion so that his wings seem too far back. As he flies over, you note his hig, heavily-rerested head. his dark collar, 
and his glistening white throat. If he lights on a dead stul, by the water, and you can sce the compact, oily plumage that is adapted for cold plunges, you will think him hamdsome in spite of his topheaviness. He sits like the catbird, and watches the fish come toward the surface. But before they know what has happened they are wriggling in his bill. After atching a fish he quickly carries it back to his perch, to be devoured at his leisure.

The kingfisher shows us a new style of nest, though it might seem that there had been variety enough before. There was the "alobe house" of the robin, the coarse bundle of sticks gathered by the crow, the exquisite lichen-covered cup of the humming-lirel, the loose, dumsy-looking nests of the cathird and cuckoo, the frame house rented by the bluebird, the tiny wall pocket glued to the chimmey by the swift, the grass houses of the bobolink and meadow-lark, the mud bowl of the barn swallow, the airy gray pocket of the oriole, and the smug woolen retreats of the chickirlee and yellow hammer. But here is something stranger than any of them - a hurrow in the earth, that might well he the hole of some shy animal rathex than the home of a birt. It is usually due in the banks of rivers or streams.

As the kingfisher spends most of his time on the wing, his feet are small and weak, different enough from the powerful feet and claws of the 
blackbirds and orioles. What a woodsman the kingfisher must be! Do the hemlock's longest branches tip to the east? Does the lichen grow on the north side of the trees? Ask him for his compass. He needs no trail. Follow him and he will teach you the secrets of the forest. For here lies the witcheraft of our new world halcyon. rather than in the charming of sailor's' lives, or in the stilling of the sea.

\section{XVII.}

\section{CHIP-BIRD OR CHIPPY; H.IIR-BIRD; CHIPPING SPARROW; SOCIAL SPARROW.}

WE have already had "chimmey swallows" that were not swallows, crow hlackloirds that were not crows. partridges that were grouse, and kingfishers that dug holes in the ground, besides bluebirds and humming-birds and robins and chickadees and catlirich and cuckoos, all crowded together; and now we are coming to that rexatious family, the sparrows. How can any one be expected to remember such a medley long enough to know the birds out of doors? I never really knew them until I pigeon-holed them, and I helieve that is the best way. But how shall we go to work?

Ornitholngists separate our birds into seventeen orders, and divide these into numerous families and genera and species. Wre should have to turn 
pension-office clerks to get pigeon-holes enough for them! But twelve of the serenteen we shall leave entirely alone, - the divers, all kinds of swimmers, waders, herons, cranes, parrots, and other's that most of us never see outside of musemus. Of the five order's left, four are quickly disposed of. The partridge will be our only representative of the "gallinaceous birds," the cuckoos and lingfishers of the order of "cuckoos, etc.." the woolpeckers of the "woolpecker's, etc.," and the swift, humming-bird, night-hawk, and whippoorwill of the "goatsuckers, swifts, etc."

There are so few of these, and they are so scattered, that it does not seem worth while to give up part of our pigeon-holes to them, so we will put them away in a drawer by themselves, and keep our pigeon-holes free for the one order left, - the highest of all, - that of the "perching birks." It has twenty-one families, but we need only fourteen holes because there are seven families that we shall not take up). So our best way is to paste the label "perching hirds" over om fourteen holes, and then, while remembering that we have left out seven families, number each hole and put in the bircls as they come in their natural order of development from low to high.

The crow goes in No. 2 by himself at present. The bobolink, meadow-lark, crow blacklbird, and miole all go into No. 3, because they belong to the family of "blackibircls, orioles, etc.," although they 
represent different branches, or genera. Chippy goes into No. 4 to wait for the other "finches, sparrows, etc.." the barn swallow will go into No. 6 , which belongs to "the swallows," the catbird into No. 10, the chickarlee into No. 12, and the robin and bluebird into No. 14. - - the last hole, as they belong to the most highly developed family of all the birds, that of the "thrushes, bluebirds, ete."

This simplifies matters. The chimney swift belongs to an entirely different order from the swallows, - a much lower one. - and so was put in the drawer, together with the kingfisher, whose feet are weak and who nests in the ground. Now all the "perching birds" we have had fall readily into place. The "row is ly himself in No. 2, as the blacklireds in No. 3 differ from him in having: wires smaller than themselves, and in anatomical and technical peculiarities that are the foundation of all the divisions we have.

But here is chiply in No. 4: let us see how he is related to the other hirds. First, what does he look like"? Although one of those "little gray birds" that rex the spirit of the tyro, he is well known as the smallest and most friendly of our sparrows. All the sparrows are small, dull colored bircts, none of them being much more than half as laroe as a robin. Thut he is marked by a reddishbrown carp, edged by a delicate white line over eye and cheek. His back is streaked with g'ayish- 
brown and blatek, his wings are crossed by narrow whitish bars, and underneath he is a pure light ash color.

Notice the hill chippy has to crack seeds with. It is the short, thick, conical bill of the fanily, and contrasts not only with the long slemeler bills of the worm-eating robin and bluebird in $\mathrm{N}$ o. 14 , but with those of the oriole, "row blacklired, and meadow-lark in No. 3. The bololink shows the nearness of No. 3 and $t$ in his partly conical bill, and also in flight, though, by coloring, he is more closely related to the (row in No.2. It is hardly necessary to suggest the differences that separate chippy from the chimney swift, the ruffer grouse, the humming-bird, the cuckoo, and the ant-eating yellow hammer.

Of our common sparrows chippy alone has no real song, but he trills away monotonously, by the hour, you are tempted to think, - with cheerful perseverance that would grace a hetter. cause. He is called "hair-hird" because he lines his nest with horse or cow hair, and when you think of the close olservation and industry it takes to find this hair you will recosnize not only the power of inherited habit but the fitness of the name hair-bird.

Last summer a chipping sparrow built in a jasmine bush in the aroteh of a neighbor's piazza. When the little mother was startled by intruder's she would dart into the hush, (arouch down, Hattrin 
her head, and try to make herself invisible, but she had too many frights and at last abandoned her nest. In a grape-vine on top of a trellis in the garden in front of the cottage another chippy had built. She seemed to be fearless, never stirring even when we stood at the foot of the trellis and stared at her.

I found several nests in Norway spruces. One was near a farm-house. It was on a bough hidden so skillfully under an evergreen twig that I had much ado to find it, and there was barely room for even the small mother bird to get up to it. But the four little rlark hlue eggs wreathed with purplish dots around the larger ends, as they lay clustered on their mat of brown rootlets, made a sight to repay a longer hunt. With all her care the poor mother was not able to conceal her little ones. A hungry chipmunk discovered them, and was shot by the farmer when it was swallowing the last one of the four.

In summer the chipping birds haunt the piazza, coming almost to our feet for crumlss. Last season two broods were brought by their mothers, and it was diverting to watch them. The mothers drove each other about in a scandalous fashion, and, what was worse, would not feed each other's children, but turned their hacks in the most hard-hearted way even when the hungry youngsters ran up in front of them and stood with wide open bills teasing for fool. As the babies grew older I suspect 
their mother's poisoned their minds, too, for as nearly as I could make out a coldness grew up ber tween the families of infants.

The old chipling birds are very intelligent. The tum of the head and the puick glance from the eye show that their familiar havery is due to no thoughtless confidence, but is based on keen observation and bird wit.

The young birds seem more trustful and are dear fluffy little creatures. When they get to be as big as their mother's and know perfectly well how to feed themselves, the lazy babies will often stand helplessly right in the middle of a handful of erumbs, and chirr at their mother till she picks the crumbs up and drops them in their bills.

One day I found a young chiply sitting on the picket of a fence. His mother soon Hew up onto the picket next to him with his dinner in her bill and leaned over trying to reach it across. It was a comical proceeding, the baby fluttering his wing's, opening his mouth, crying out and bohbing toward his mother while she stretched across till - well, both birds came near a tumble before they gave it up.

Chipping bircls are always about, in the garden, on the lawn, and around the house. The hack door with its boumlless possibilities in the (rumh) line attracts them strongly. At one house, for several years, a number of them came to the back yard every day when the chickens were fecl. They 
sat on the fence till the first rush and scramble were orer, and then flew down among the hens to get their dinner.

\section{XVIII.}

SONG SPARROW.

Tue song sparrow, of course, goes into the same pigeon-hole as chiply - No. 4, "finches, sparrows, etc.," - showing the same sparrow traits in coloring, size, bill, and flight; and the same contrasts with the crow in No. 2, the " blackbirds, orioles, etc.." in No. 3, the "swallows" in No.6. and the rolin and bluebird among the " thrushes, bluebirls, ete.." of No. 14. But with all this, our little friend has a marked individuality, and differs from his small cousin chiply in temper and charm. I may be prejudiced, but while I admire chipry for his hravery and intelligence I do not find him as winsome as this simple little bird with his homely cheeriness.

In the spring the song sparrow comes North a few days after the rolin, and although the chill from the snow hanks gives him a sore throat that makes his voice husky, you may hear him singing as brightly as if he had come batck on purpose to bring spring to the poor snow-bound farmers. Even his (hirp) - of rich ('ontralto (yuality compared with the thin chip of his cousin - has a 
genuine haply ring that raises one's spirits; and when he throws up his heal and sings the sweet song that gives him his mane, you feel sure the world is worth living in.

The song sparrow's brown coat has little beauty, but his dark breastpin, surrounded by brown streaks, sets off his light gray waistcoat to advantage; and the brown topknot that he raises when interested gives him a wimning air of sympathetic attention.

The song sparrows are not alont the house as much as the chippies, and last summer they began coming for crumbs a week later in the nesting season than theiv uloipuitous rousins. Then it was ammsing to see the business-like way in which they hopped about, their tails perked up and their wings close to their sides. There was one that walked like a blackbird, and when he ran it seemed a waste of energy - he had so much more to do than if he had hopped!

The usual note of the song sparrow is a rich "tschip," as Thorean gives it; but when nesting it has an odel thin chip that somds so like the note of a young bird that it deceived me into hunting through the bushes when the old hird who was really making it was in plain sight. The sparrow's song is the first set song likely to attract your attention when listening to the birds near the house, and as Thoreau says, is "more honestsounding than most." The song consists of one 
high note repeated three times, and a rapid rum down the scale and back; but it varies greatly with individuals, and almost every writer render's it differently.

In choosing the site for its nest, the song sparrow adapts itself to circumstances with the grace of a true philosopher. At one time content with making a rudle mat of straw at the bottom of a roadside brush heap, at another it builds in a willow, using the woolly catkins to soften the bed; and frequently it nests right on the ground, when the farmers call it the "ground sparrow." But the prettiest site of any I have ever known was in a sweetbriar bush on the edge of the garden. Here the little mother could be lulled into her noon-day nap) by the droning of the bumble-bees buzzing about the garden; or, if she chose, watch the fluttering butterflies and quivering hummingbirds hovering over the bright flowers. Every breath of air brought her the perfume of the briar leaves, and when the pink buds unfolded she could tell off the days of her brooding by the petals that fluttered to the ground. 


\section{XIX.}

BLUE JAY.

The blue jay comes with a dash and a flourish. As Thoreau says, he "blows the trumpet of winter." Unlike the chickadee, whose prevailing tints match the winter sky, and whose gentle dayday-day chimes with the softly falling snows, the blue jay would wake the world up. His "clarionet" peals over the villag'es asleep in the snowdrifts as if it would rouse even the smoke that drowses over their white roofs. He brings the vigor and color of winter. He would send the shivering stay-at-homes jingling merrily over the fields, and start the children coasting down the hills. Wratie-up, realie-rip, come-out, come-out he calls, and blows a blast to show what winter is good for.

And so he flashes about, and screams and scolds till we crawl to the window to look at him. Ha ! what a handsome bird! He has found the breakfast humg on the tree for him and cling's to it pecking awa with the appetite of a Greenlander. Not a hint of winter in his coloring! Note his purplish back as he bends over, the exquisite coloalt blue, touched off with black and white on his wings, and the black barring on the tightly closed tail he is braving himself by. How distincuished his dark necklace and handsome blut 
crest make him look! There! he is off again, and before we think where he is going we hear the echo of his rousing phe-phary, phe-phary frem the depths of the woods.

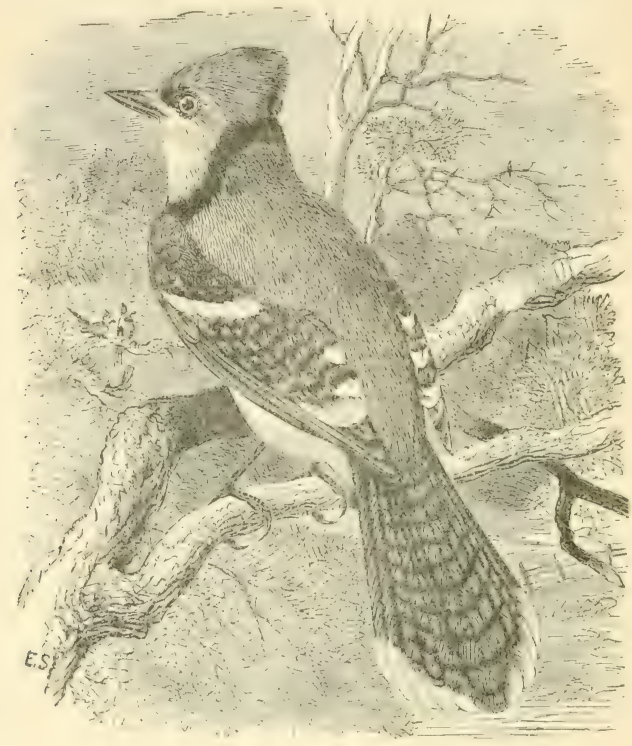

In many places the jays are common winter residents, pitching their tents with the hens and barnyard animals and comporting themselves with familiar assumance. But in this region they are irregular guests. Sometimes they are here for a few days in the fall, or visit us when the hawks 
return in spring, teasing the young observer by imitating the cry of the redtailed hawk. But if the fancy takes them they spend the winter with us, showing comparatively little of the timidity they feel in some localities.

Last fall a party of jays stayed here for some time, but when I was congratulating myself on having them for the winter, they left, and did not return till the middle of January. Then one morning one of them appeared suddenly on a tree in front of the window. He seemed to have been there before, for he flew straight down to the corn boxes by the dining-room. The oray squirrels had nibbled out the sweetest part of the liemels, and he acted dissatisfied with what was left, dropping several pieces after he had picked them up. But at last he swallowed a few liernels and then took three or four in his bill at once and flew up) in a maple. He must have deposited some of them in a crotch at the botly of the tree, for after he had broken one in two uncler his claw - striking it with "sledge-hammer blows " - he went back to the "roteh, picked up something, flew back on the branch, and went through the process orer again. The second time he flew down to the corn boxes he did the same thing - ate two or three kernels, and then filled his bill full and flew oft - this time out of sight. Since then I have often seen him earry his corn off in the same way, giving his head a little tosis to throw the liernels back 
in his bill as he was loading up. Wilson calls atterition to the fact that by this habit of carrying off kernels and seeds, the jay becomes an important tree-planting agent.

What a good business man the blue jay would make! All his motions are like the unique loading up performance - time - saring, decided, direct. Once during the first morning after his return he flew down to the boxes from the tree over them and came so straight he looked as if falling through the air. He pecked at the bark of the trees as indifferently as he had examined the corn the squirrels had nibbled, but I thought he drank with some gusto. He secmed to be catching the rain drops that were running down the sides of the trees and filling the crevices of the bark.

After he had flown off and the gray squirrels were comfortably settled at breakfast, he came dashing back round the corner in such a hurry he almost struck the squirrel on the lower corn box. The first thing I saw was a confusion of blue feathers and gray fur, and then a blue jay flying off to the evergreen, and a gray squirrel shaking his tail excitedly and starting from one side of the box to the other trying to collect his wits. By this time the blue jay had recovered from his surprise, and seeing that it was only a squirrel, hopped about in the spruce als full of business as if the collision had been plamned. Not so with the poor squirrel: IIe sprang up on the 
highest box, stretching straight up on his hind leg's, with fore paws pressed against his breast and ear's erect, his heart beating his sides and his tail hanging down shamefacedly as he looked anxiously toward the spruce where the blue jay had gone. Gradually the fear on his face changed to a comical look of bewilderment. Could that bird flying about as if nothing had happened be what struck him, or had he gone to sleep over his corn and had a bad dream? He settled down on his haunches with an expression of inane confusion, and finally turned back into his corn box, a sorry contrast to the clear-headed blue jay.

This was the first morning the jays came, and we were greatly entertained watching the development of affairs. There were only three birds that were regular patrons of the corn barrel restaurant, while there were thirteen gray squirrels, and when the squirrels got over their first surprise they seemed to consider the jays an insignificant minority. There were no claw-to-bill tussles, for when a jay was eating on a corn box by the side of the tree, and a squirrel ran down the trunk right above him, and gave a jump that promised to land him on the jay's head, the bird would quietly fly off. But such meekness was no sign of discomfiture. The jays came back as often as they were driven away. If the squirrels ol)jected to their eating on a corner of the box with them, the jays would hop down on the snow and 
pick up the corn the squirrels had scattered there. They were so persistent, and at the same time so dignified and peacealie, that the squirrels could not hold out against them; and though for a time the birds took advantage of the squirrels' laziness and got a good breakfast morning's before the sleepy fur coats appeared, two or three weeks of $10^{\circ}-20^{\circ}$ below zero silenced the squirrel's last prior-claims argument and the jays were allowed to eat undisturbed from the same boxes with them.

But it is not only the squirrels that the blue jays dine with, for one day last winter the little three-year-olel came ruming out of the diningroom in great excitement, (rying, “ Oh, grandpa ! come quick: There are three partridges, and one of them is a blue jay!" Indeed, the other day the blue jays quite took possession of the corn barrels that are the special property of the partridges. The harrels stand under the branches of a Norway spruce on either side of a snow-shoe path that rums from the house, and though the jays were self-invited guests, I could not help admiring the picture they made, they flying about and sitting on the harrels, the dark green of the boughs bringing out the handsome blue of their coats.

But the spot where I have found the blue jays most at home is in the dense coniferons forests of the Adirondateks. I shall nerer forget seeing a 
Hock of them on Black Momtain. From the top of the mountain the wilderness looked like a sea of forest-clad hills, with an occasional reef outlined by surf, for the largest lakes seemed like tracery in the vast expanse of forest. The inpressive stillnessis was broken only by the rare cries of a pair of hawks that cireled over the mountain; for the most part they soared, silent as the wilderness below them. Coming down into the forest primeval, where the majestic liemlocks towered straight toward the sky, and their massive knotted roots bound down the granite bowlders that showed on the mountain side-- there we found the blue jays in their home. I flock of them lived together, feeding on wild herries and beechmuts, sporting among the ferns and mosses. and drinking from the brook that babbled along near the trail. What a home our handsome birds had chosen! But the memory of the spot is dreary. Unmoved by the beauty of the scene, to which the blue jays gave color and life: unawed by the benedirite of the hemlocks; betraying the trust of the friendly birds, the boy of the party crept into their very home and shot down one after another of the family as they stood resistless before him. To-rlay the pitiful lament of the brave oid birds haunts me, for, forgetting to fear for themselves, those that were left flew aloout in wild distress, and their cries of almost human suffering reached us long after we had left the desecrated spot. 


\section{XX.}

YELLOW-BIRD; AMERICAN GOLDFINCH ; THISTLEBIRD.

THRow yourself down among the buttercups and daisies some cloudless summer day and look up at the sky till its wondrous blueness thrills through you as an ecstacy. Then catch your breath and listen, while out of the air comes a clear fluid note of rapture. Ah ! there is the little goldfinch - a bit of the sum's own gold sauntering through the air, rising and falling to

the rhythm of his own
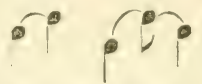

This way and

dee-ree dee-ee-ree.

that he flits, at each call fluttering his wings and then letting himself float down on the air. Spring up from the mearlow and follow him till down from the blue sky he comes to alight airily on a pink thistle-top. Then as he bends orer and daintily plucks out the tiny seeds that would soon have been ballooning through the air. you can admire the glossy black cap. wings, and tail that touch off his slender gold form.

Who would ever take this fairy-like beauty for a cousin of our plain chippy and song sparrow? And yet - his bill and size and family traits are the same. Pigeon-hole No. 4 was marked "finches, sparrows, etc.," and he is one of the 
finches. He seems near enough like the sparrows too, when you think how unlike he is to the blackbirds and orioles of No. 3, or the swallows of No. 6 , the cathird of No. 10, and the robin or bluebird of No. 14.

Even the chickadee from No. 12 is a strong contrast to him. His slender frame fits him for.

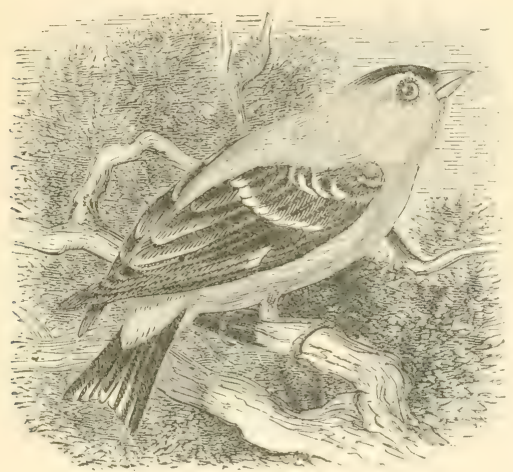

flying through the air, while the chickadee's plump, fluffy figure is suited to flitting about treetrumks and branches. Early in the spring the chickadee goes to the woods, and, using his pointed bill as a pick-axe, picks ont a nest hole in the side of a stump or tree trunk. But the goldfinch waits until July, and then, going to the nearest orehard, (chooses a plum or apple-tree crotch and sets about making a basket to fit it. He peec]s 
the bark from some slender weed for the outside, and pilfer's a thistle-top or the silk storeroom of some other plant for a lining.

An old nest the children brought me last fall had a veritable feather-bed of down in it, on top of the usual silky lining, and it stuffed the cup so full there seemed hardly room enough for the eggs. It looked as if two or three whole thistletops had been put in and matted down.

Last year a pair of goldfinches built in a plumtree by the side of a carriage drive, so low that on tiptoe I could reach into the nest to count orer the egg's from day to day. And what dainty light blue shells they had. Just as if bits of blue sky harl fallen into the nest: The mother-bird must have guessed my delight in her treasures, for she would sit quietly on a tree a few feet away with an air that said quite plainly, "Are n't they dear' little exgs? You can look at them just as long as you like. I'll wait here till you get through!" As the goldfinches nest so much later than most hirds, the young are barely out before the warlders and other of the birds begin migrating. I have seen the little ones teasing their father for food late in September. One day I saw one fed on the head of a big sunflower.

I am afraid Mr. Goldfinch is not a good disciplinarian. for his babies follow him around fluttering their wing's, opening their mouths, and 'rying tuect-ee, tuect-ee, tweet-ee, trecet-ce, with 
an insistence that suggests lax family government. Some one should provide him with a bundle of timothy stalks! And yet who would have our fairy use the rod? Just listen to him some day as he flies away from his nest, singing orer to himself in tones of exquisite love and tenderness his sweet bray-bee, bring-ec-bee, and you will feel that the little father has a secret better than any known to the birch.

Our goldfinch is not a musician when it comes to his long song. That is a canary jumble of notes whose greatest charm is its light-heartedness. But though he is not as finished a songster as the canary, during the summer he is much prettier, for then his yellow suit is richly trimmed with black markings. In September however he loses his beauty, and until the next April or May, when his perilous travels are over for the season, looks much like his plain little wife. His black trimmings are gone, and he has become flaxenbrown above and whitish-brown below, - quite commonplace.

In comnection with this protective change in plumage the "Naturalist" gives an interesting instance of protective habit, in which the wise birds disguised themselves hy the help of their bright summer coats. A flock of them were dining on top of the stalks of yellow mullein that covered the slope of the embankment by which the observer and his party passed. He says: "The 
mulleins were ranged in stiff files, like soldiers in yellow uniforms, and each lird as we passed remained motionless, looking like a continuation of the spike, of which one might easily be deceived into thinking it part and parcel. As soon as we had passed by, the birds were again busy, flitting from plant to plant, feeding on the seeds and enjoying themselves."

What a difference it makes in our thought of winter to know that our little goldfinch will never find it too cold to visit us. Being a vegetarian, his storehouse is always well filled, for if the snow covers the seeds he would gather from the brown weed tops, he goes to the alders in the swamp; and if they fail him he is sure to find plenty in the sceds of the hemlock, the spruce, and the larch.

\section{XXI.}

PHCEBE.

Classing the crow-blacklird, bobolink, and oriole together in No. 3 by their striking colors, and distinguishing the sparrows in No. 4 by their striped backs, the common flycatchers, who belong in our first pigeon-hole, No. 1, stand out as unstriped, dull, dark grayish birds, with light breasts. Mr. Burroughs describes them as "sharp-shouldered, big-headed, short-legged, of no particular rolor, of little elegance of flight or movement." 
Knowing that the vocal organs of the flycatchers are undeveloped, you are not surprised by the contrast they present to the sweet-voiced sparrows and finches, the talkative catbird, and the bobolink, who is always bubbling over with song, nor (1) you wonder at the abrupt all of the phobe. Although it resembles a jerking repetition of pher-be, pha-be, it is not precisely what the word would indicate. The first part of the call is comparatively clear, but the second is a longer rasping note, with a heavily trilled $ı$, making the whole more like pho-ree, phoe-ree.

When the birds first hegin coming north you hear this note. When you have traced it to its source, - and it is an excellent habit to see every bird whose notes attract your attention, - the dull olive gray coat and the whitish rest, with its tinge of pale yellow, are soon forgotten in watching the odd ways of the bird.

Somewhat longer than a song sparrow, - two thirds as large as a roljin, - he is strikingly unlike the cheery, busy sparrow, or, in fact, like any of the birds we have had. There he sits on a branch, in an attitude that would shock the neat somgster's. His wing's droopl at his sides, and his tail hang's straight down in the most nexgligent fashion. He seems the personification of listlessness; but, focus your glass on him, - his wings are vibrating, and his tail jerlss nervously at intervals. Sudlenly he starts into the air, snays his bill loudly over an 
unsuspecting insect he has been lying in wait for, and before you breathe settles hack on the branch with a spasmodic jerk of the tail.

And now, as he sits looking for another victim, you have a good chance to note, through your glass, the peculiarities of the bill that gave such a resounding ".click." Birds" bills are their tools, - the oriole's is long and pointed for weaving, the chickadee's short and strong to serve as a pickaxe: but when the nest does not call for a tool of its own the bill conforms to the food habits of the bird, - as the white man is needs are met by knife and fork, and the ('hinaman's by chop)stickis. So the bills of the robin and bluebird, you remember, are long. thin, and slender, - well fitted for a worm diet, - while the sparrows, who live mostly on seeds, have the short, stout. coneshajed firch bill. In the same way flycatchers bills are specially atapted for their use. that of catching the insects upon which they live. At the base there are long stiff bristles, and the upper half of the bill hooks over the lower so securely at the end that when an insect is once entrapped it has small chance of escape.

The pheche is fond of builring in a croteh of the piazza. on the beams of old sheds. and under bridges, apparently indifferent to the dust and noise of its position; but away from the immediate haunts of man it usually nests in caves or rocky ledges, and sometimes takes possession of the up- 
turned roots of a fallen tree. I well remember finding a cave nest when we were children. We let ourselves down into the cave by a crevice in the lime rock, and after groping our way among the loose stones that made the floor, and - as om anxious fathers insisted - the roof of the cave, crawling along low passages, wedging between narrow walls, and hunting for stepping stones across the dark pools that reflected the glimmer. of our candles, we suddenly came into a flood of daylight, - a crack in the rocks wide enough to make a dangerous pitfall for the horses and cows that grazed overheal, but chosen by the phorbes as the safest possible nook for rearing a lorood of baby birds. Down the sides of this shaft the rain trickled, keeping the moss green and giving the tiny ferns strength to cling to the cramnies of the rock. On a ledge just in reach of the tallest of us the wise pair of birds had built their nest. caldeless of the dark cavern below, and happy among the moss and ferms.

\section{XXII.}

\section{KINGBIRD ; BEE MARTIN.}

THE kingloird is noticeably smaller than the robin, but is larger and more compactly built than most of the flycatcher's. The sobricty of his plain blackish coat and white rest are relieverl hy a colored patch that may sometines be espoied under. 
84 BIRDS THROUGH AN OPERA-GLASS.

his crest, and also by a white tip to his tail, which, when spread in flight, has the effect of a white crescent. He has a peculiar flight, holding his head up and using his wings in a labored way as it he were swimming. When looking for his dinner he often flutter's obliquely into the air, displaying his shining white breast and fan-shaped tail to the best advantage.

All the disagreeable qualities of the flycatchers seem to centre in this bird. Ilis note is a harsh, scolding twitter. His rown proclaims him king. not by right, but by might. - such a bickering pugilist, such a domineering antocrat he is. The crow's life becomes a plague when this tormentor gives chase; and the smaller birds find themselves driven at the point of the bill from the fences they had considered pullic highways.

But whatever may be the exact limit of his quarrelsomeness it stops short at home: old kinghirds are certainly tender guardians of their young. I once watched a pair in search of food. They flew down to the haycocks in the meadow near the orchard, sat there recomnoitring for a moment, and then jumped into the grass to snap up the insect they had discovered. Flying back to the young they flirted their wings and tails as they dropped the morsel into the gaping red throats, and in an instant were off again for a hunt in the air, or in another tree. And so they kept hard at work, looking everywhere till the 
voracious appetites of their infants were satisfied. DeKay says of the kinglird"s diet: "He feeds on berries and seeds, beetles, (anker-worms, and insects of every description. By this, and by his inveterate hostility to rapacious birds, he more than compensates for the few domestic hees with which he varies his repast." To this Deliay adds the interesting statement: "Like the hawks and owls, he ejects from his mouth, in the shape of large pellets, all the indigestible parts of insects and berries."

\section{XXIII.}

WOOD PEWEE.

Is size, coloring, and habit you will hardly distinguish the wood pewee from the phobe, although the former is somewhat smaller. These two birds stamd apart from all the others we have had. The chimmey swift and barn swallow also live on insects, but measure the difference in their methods of hunting. The swift zigzags through the air, picking up his dimner as he goes; the swallow slims the rivers, and circles over the meadows and through the sky, without so much as an ungraceful turn of the wing to suggest that he is dining. But the phobe and the woorl pewee lie in wait for their victims. They cmmingly assume indifference until the unwary ganzy-wing floats within lange, then spring on it, snap it up, and fall hack to wait for another unfortunate. 
And when not hunting, how silent and motionless they sit, the phœhe on the ridgepole of a barn, the wood pewee on a twig in the flickering sumlight and shade of the green woods: neither of them uttering more than an occasional note, and searcely stirring unless to look over their shoulders.

Though the phobe and wood pewee look so much alike, in reality they are as much at odds as a farmer and a poet. Unlike the nest of the phobe, the wood pewee's is essentially woodsy and distinctive. It is an exquisite little structure, saddled on to a lichen-covered limb. Made of fine roots and delicate stems of grass and seed pods, it is covered with lits of lichen or moss glued on with saliva, so that like the humming-bird's nest it seems to be a knob on the branch. It is a shallow little nest, and the four richly crowned creamy eggs, though tiny enough in themselves, leare little room for the body of the brooding mother.

In temper the phobe is so prosaic that we naturally comnect it with the beams of harns and cow sheds: while the wood pewee, associated with the cool depths of the forest, is fitted to inspire poets, and to stir the decpest chords of human nature with its plaintive, far-reaching roice.

It has moods for all of our's. Its faint, lisping

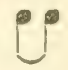


suggests all the happiness of domestic love and peace. At one moment its minor

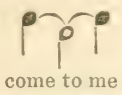

with the liquidity of a " U " of sound

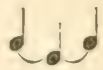
is fraught with all the pathos and yearning of a desolated human heart. At another, its tender, motherly

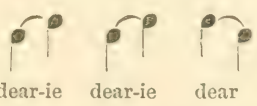

with which it lulls its little ones, is as soothing to the perplexed and burlened soul as the soft breathing of the wind through the pine needles. or the caressing ripple of the smset-gilded wares of a mountain lake.

\section{XXIV.}

\section{LEAST FLYCATCHER.}

If you have been in the country, or even in one of om smaller towns during the spring and summer, you may have noticed the reiteration of an abrupt call of two notes - che-becli' che-berli' coming from the apple-trees and undergrowth. If you have traced it you have discovered a small gray lind, in coat and habit a miniature of the phoebe and wood pewee, jerking not only his tail but his whole body with his emphatic call.

This small bird seems a piquant satire on the 
days of tournament and joust, when knights started out with leveled lances to give hattle to every one they met. He is a fearless little warrior, snapping his bill ominously as he charges, full tilt, at his enemy.

Last summer on passing a thicket I heard this smapping, together with loud calls of che-bect.', and stopped to see what was happening. There, in a low willow, I found a family of young sumning themselves while their mother brought them their dimner. It seemed a most peaceable scene, but a picket fence ran along just back of the willow, and I soon discovered that this was the tilt yard. Whenever a song sparrow or pewee happened to light there and stretch its wings for a sum bath, the fierce little mother would suddenly appear, dart at the unoffending bird, and fairly throw him off the fence with her abrupt onset.

After unseating her enemy she would fly off as fast as she had come, career about in the air till she had snapped up) a fly or miller, dart back, thrust it into one of the open mouths with a jal, that threatened to decapitate the little one, and seemed to mean, ". There, take it quick if you "ve got to have it," and with a Hirt of the tail and wings, before I had time for a secomd look, would be off in hot pursuit of another inseret.

I wanted to see if she woukl he afraid of me, and so (repe up by the fermce. almost under the baby birels. Two of them sat there side by side, 
in the most affectionate mamner, nestling down on the branch with their soft white feathers fluffed out prettily. They did not mind me, and closed their eyes as if the warm sunlight made them sleepy. All of a sudden their mother flew up to one of them with a fly, but was so startled on seeing me that instead of giving it to him she sprang up on top of his head and was off like a flash, almost tumbling him off the branch, and leaving him very much scared and bewildered. As soon as her nerves recovered from the shock she came back again and went on with her work as if I had not been there. The father seemed to be as restless and pugnacious as the mother, and, if appearances were to be trusted, was quarreling with his neighbors in a tree near by, while his wife guarded the picket and fed her young.

\section{XXV.}

RED-IVINGED BLACKBIRD.

Tre large flocks of blackbirds seen coming north in the spring are confusing at first, lut by careful olservation you will soon be able to discriminate between them. Sometimes the crow blackbird and the red-wing fly together. but they more commonly go in separate flocks. At a clistance, the flight of the two is perhaps the most distinctive feature - the "keel-tail " steering ap- 
paratus of the crow blackbird marking him anywhere. Then, though they both belong in the same pigeon-hole, the keel-tailed is a half larger, and the red-wing a trifle smaller than the robin. Known more familiarly, the recl-wing lacks the noisy olstrusiveness of his awkward cousin, and usually prefer's the field to the dooryard.

Though as I write the roads are being broken through the drifted snow by plough and kettle, as I turn over the crumpled leaves of the small notebook I have carried on so many tramps, the first faint. penciled notes I find on the red-wing take me back into May, and, in fancy, we are again starting down the hill to the swampy meadows where

"The red-wing; flutes his o-ka-lee."

Did you ever see a meatow full of cowslips? Here is the true field of the cloth of gold. It looks as if father. Sun had crumbled up sunbeams and soattered the hits orer the meadow! As you sink into the soft wet ground, every few steps lning you to a luxuriant (clump of the tender green plants lit up) by flower (ups of glistening golil. Earch bunch seems more beantiful than the last, and, like a child, I would carry the whole field full of flowers home in my arms ! This sumgarden is the red-wing s playgroumd. As we stroll along. he flies over our hearls calling out o-kect-lee, and then. with outstretrhed wings, soars slowly down to the ground, where he sits and wags his tail as fast as a catbird. 
As Thoreau says, his red wing marks him as effectually as a soldier's epaulets. This scarlet shoulder cap is so striking against the hircl"s hlack coat that the careless observer does not notice its border of brownish yellow, even when it shades into white, as it does in some of the western species. With Madam Blackbird the contrast is not so great, for she is not as pure black as her. husband, having brownish streaks that, even at a distance, give her a duller look; and then her epaulets are more salmon than scarlet. Sitill the effect is pleasing, and it is only a matter of taste if we do not admire her as much as her spouse.

I was mable to go to the meadows during the nesting season, and the next notes I find in my book were taken in the midlle of June. Then the young were hidden in the grass, and the old birds followed us from spot to spot, screaming loudly as they circled near us, or hovered low over our hearls. Perhaps their cries were to warn their children, for, although there were three of us, and we examined carefully all the places where they showed the most concern, we surceeded in searing up only one rusty-coated youngster.

Two weeks later, in the warm days of ouly. the red-wings seemed to have left the meadows for the trees that skirted the alder swamp) and families of old and young were sitting with their rousin grackles in the willows and on the rail fence, while some flew up as I walkexl through an 
opening in the swamp) where the cat-tails stood guard, and the long-banded rushes soughed like wind in a forest.

\section{XXVI。}

\section{HAIRY WOODPECKER.}

THE habits of the woodpecker family are more distinctive, perhaps, than those of any group of the birds we have been considering, and the most superficial observer cannot fail to recognize its members.

Troortpectiers - the very name proclaims them unique. The robin drags his fish-worm from its hiding place in the sod, and (arols his happiness to every sumise and surset: the sparrow eats crumbs in the doorvard and builds his nest in a sweetbriar; the thrushes turn over the brown leaves for food and chant their matins among the moss and ferns of the shadowy forest; the goldfinch balances himself on the pink thistle or yellow mullein top, while he makes them " pay toll" for his visit, and then saunters through the air in the aloandonment of blue skies and sumshine; the red-wing flutes his o-lict-lee over cat-tails and cowslips; the bobolink, forgetting everything else, rollicks amid buttereupss and daisies; but the woodpecker finds his larder under the hard bark of the trees, and. oblivious to sumrise and sunset, 
flowering marsh and laughing neadow, clings close to the side of a stub, as if the very sun himself moved around a tree trunk!

But who knows how much these grave monomaniaus have discovered that lies a sealed book

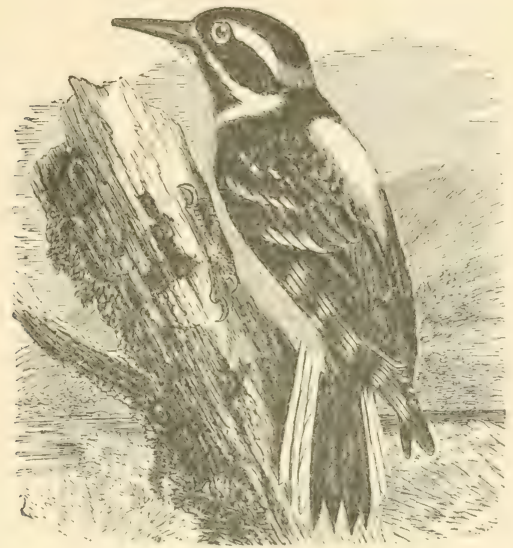

to all the workl besiles? Why should we scom them? They are philosophers! They have the se(ret of happiness. Any bird could be joyous with plenty of blue sky and sumshine, and the poets. from Chaucer to Wordsworth, have relaxed their brows at the sight of a claisy; but what dloes the happy goldfinch know of the wonders of tree trunks, and what poet could find inspiration in a dead stul, on a bleak Norember day? Jack Frost sends both thrush and goldfinch flying south. and 
the poets shut their study door's in his face, drawing their arm-chairs ul, to the hearth while they rail at Norember. But the wise woodpecker rling's to the side of a tree and fluffing his feathers aloout his toes makes the woods reverberate with his cheery song, - for it is a song, and bears an important part in nature's orchestra. Its rhythmi(cal rot t(1), trlp), t(1), t(1), not only beats time for the chickadees and nuthatches, but is a reveille that sets all the brave winter blood tingling in our veins.

There the hardy drummer stands beating on the wood with all the enjoyment of a drum major. How handsome he looks with the scarlet (aip) on the back of his head, and what a fine show the white central stripe makes against the glossy black of his back !

Who can say how much he has learned from the wood spirits? What does he care for rain or blinding storm? He can never lose his way. No woodsman need tell him how the hemlock branches tij), or how to use a lichen compass.

Do you say the birds are gone, the leares have fallen, the bare branches rattle, rains have blackened the tree trunks? What does he care? All this makes him rejoice: The merry chickatee hears his shrill call above the moaning of the wind and the rattling of the branches, for our alchemist is turning to his lichen workshop.

The sealed book whose pictures are seen only 
by children and wood fairies opens at his touch. The black unshaded tree trunks tum into enchanted lichen palaces, rich with green and gold of every tint. The "pert fairies and the dapper" elves" have left their magie circles in the grassis, and trip lightly around the soft green relvet moss mounds so well suited for the throne of their queen. Here they find the tiny moss spears Lowell christened, "Arthurian lances," and quickly arm themselves for deeds of fairy valor. Ifre, too, are dainty silver goblets from which they ('an quaff the crystal globes that drop one by onc from the dark moss high on the trees after rain. And there - what wonders in fern tratery, silver filigree and coral for the fairy Guinerere!

But hark! the children are coming - and off the grave magician flies to watch their play from behind a neighboring tree trunk. There they come, straight to his workishop, and laugh in glee at the white chips he has scattered on the gromul.

They are in league with the fairien, too, and cast magie spells orer all they see. Finst they spy the upturned roots of a fillen tree. It is a mountain! And up they (dimber, to orerlook thei:" little world. And that pool left by the fall rains. IIa! It is a lake! And away they go, to cross it bravely on a bridge of quaking moss.

As they pass moler the shation of a giant hemlock and piek up the cones for playthings, they artrh sight of the pile of dark reed sawrlust at the 
foot of the tree and stand open-mouthed while the oldest child tells of a long ant procession she saw there when each tiny worker came to the door to drop its borings from its jaws. How big their eyes get at the story: If the woodpectier could only give his cousin the yellow hammer's tragic sequel to it!

But soon they have found a new delight. A stem of basswood seerls whirls through the air to their feet. They all scramble for it. What a pity they have no string! The last stem they found was a kite and a spiming air-top for a day's play. But this - never mind - there it goes up' in the air dancing and whirling like a gay young fairy treading the mazes with the wind.

"Just see this piece of moss! How pretty !" And so they go through the woods, till the hrown beech leaves shake with their laughter, and the gray squirrels look out of their oriel tree trunk windows to see who goes by, and the absorbed magician - who an tell how much fum he steals from his lofty observation post to make him content with his stub!

Why should he fly south when erery day lorings him some secret of the woods, or some scene like this that his philosopher"s stone (an turn to happiness? Let us proclaim him the sage of the birds!

If he could speak! The children would gather about him for tales of the wooksprites ; the student of trees would learn ficts and figures enough 
to store a book; and the mechanice! Just watch the dexterous bird as he works !

A master of his trade, he has various methods. One day in September he Hew past me with a loud seream, and when I (ame up to him was hard at excavating. His claws were fast in the bark on the edge of the hole, and he seemed to be half clinging to it, half lying against it. His stiff tail quills helped to brace him against the tree, and he drilled straight down, making the bark fly with his rapid strokes. Then the hole did not clear itself with his blows, he would give a quick scrape with his bill and drill away again. Suddenly he stopperl, picked up something, and flew up on a branch with it. Ite had foumd what he was after. And what a relish it proved! I could almost see him holding it on his tongue.

Another day in November he had to work harder for his breakfast, and perhaps it was fortumate. The night before there had been a sharp snowstorm from the north, so that in passing through the woods all the trees and undergrowth on the south of me were pure white, while on the opposite sile the gray trees with all their confusion of branches, twig's, and noble trunks stood out in bold relief. The snow that had fallen made it rather cold standing still, and I would have been glad to do part of Mr. Inary's work myself. But he needed no help. Ile marched up the sirle of the stub, tapping as he went, and when his hill 
gave hack the somnd for which he had been listening, he began work without ado. This bark must have been harder or thicker than the other, for instearl of boring straight through, he loosened it by drilling, first from one side and then from the other. W'hen he could not get it off in this way, he went above, and below, to try to start it, so that, before he found his worm he had stripped off pieces of bark several inches long and fully two across. He was so much engrossed that I came to the very foot of the stub without disturbing him.

Indeed, woodpecker's are not at all shy here but work as unconcernedly by the side of the house as anywhere else. Once I was attracted by the cries of a hairy, and creeping up (liscovered a mother feeding her half-grown baby. She flew off when she saw me, probably warning the little fellow to keep still, for he stayed where she left him for five or ten minutes as if pinioned to the branch, crouching close, and hardly daring to stir even his head. Then, as she did not come back. and he saw no reason to be afraid of me, he flew off independently to another limb, and marched up the side arching his neck and bowing his head as much as to say, "Just see how well I walk:" 


\section{XXVII.}

\section{DOWNY WOODPECKER.}

THE downy looks so much like the hairy that it would be easy to confound them if it were not for the difference in size. The downy is fully two inches shorter than the hairy. As you see him on a tree at a distance, the white stripe on his back is bounded by black, or as Thoreau expresses it, "his cassock is open behind, showing his white robe." Above this stripe is a large check of black and white, and below on a line with the tips of his wings seems to be a fine black and white check, while, if he is an adult male, a scarlet patch on the back of his head sets off his black and white dress.

Seen only a rod away, as I see him through the window in winter, clinging to a tree, and picking at the suet hung out for him, the white central stripe of his back is marked off above by a black line which goes across to meet the blarck of his shoulders. From the middle of this and at right angle to it, another black line goes straight up towards his head, so carrying on the line of the white stripe, and forming the dividing line of the two white blocks. This, again, meets the point of a black $V$, so broad as to be almost a straight line. On this $\mathrm{V}$ lies the red patch of the back of his head. Over his eye is a white line that ex- 
tends back to meet the red patch. What at a distance looked like fine checking at the base of his wings proves to be white lining across the black.

The downy comes about us here with the same familiarity as the hairy, and it was only a few weeks ago that the cook brought me one she found imprisoned between the sashes of her window. He was scared, poor little fellow, and wriggled excitedly, trying to force my hand open. When I had taken a look at his pretty brown eyes I carried him to the front door, and off he flew to the nearest tree where he began pecking at the bark as if nothing had happened.

\section{XXVIII.}

WHITE-BELLIED NLTHATCH ; DEVIL-DOWN HEAD.

Crossbills, snow buntings, blue jays, pine finches, pine grosheaks, goldfinches, and sometimes other birds visit us here at irregular intervals during the winter, but there are four little friends that never desert us, no matter how long the winter lasts. They form a novel quartette. for the chickadee whistles the air, the muthatch sings his meagre alto through his nose, and the two woodpeckers - the hairy and downy - beat their drums as if determined to drown the other parts. But they are a merry band, with all their 
oddities, and wander about giving concerts wher('ver they go, till the wools are alive again, and we forget that we have ever missed the summer birds.

When the drums get too much absorbed in their tree trunks, the alto and air go serenading by themselves, and who knows what gossip they indulge in about the grave magicians' day dreams, or how gayly they swear to stand by each other and never be put down by these drums! They are old chums, and work together as happily as Mr. and Mrs. sirratt, the chickadee whistling his merry chich-rl-deertee, dee dee as he rling's to a twig in the tree top, and the nuthatch answering back with a jolly little yomk. yonk, yank, as he hangs, hearl down, on the side of a tree trunk. What a comic figure he makes there!

Trying to get a view of you, he throws his head back and stretches himself away from the tree till you wonder he does not fall off. Ilis black (a) and slate-blue coat are almost hidden, he raises his white throat and hreast ul' so high.

"Devil-down-hear" he is "alled firom this halit of walking" down the trees, since instead of walliing straight down backwards, as the woorlpeckers do, he prefer's to obey the old adage and "follow his nose." A latly forgetting his name once aptly describerl him to me as " that little up)side-down bird," for he will rum along the under side of a bratnch with ats much coolness as a $\mathrm{fly}$ would cross the ceiling. 
One of his popular names is "sapsucker," for our nuthatch has a sweet tooth, and when the farmers tap the trees in spring he "happens round" at the sugar bush to see what sort of maple syrup they are to have. He tests it well, taking a sip at "the calf" where it oozes out from

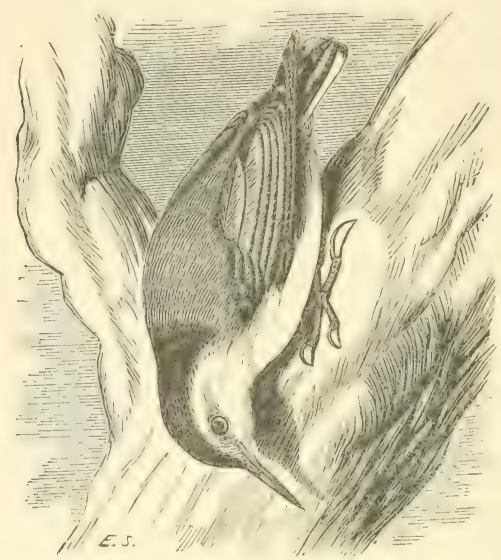

the gashing of the axe, tasting it as it dries along the spile, and finally on the rim of the buckets.

But his most interesting name is - muthatch! IIow does he come by it? That seems a riddle. Some cold Norember day put on a pain of thick boots and go to visit the heeches. There in their tops are the muthatches, for they have deserted the tree trunks for a frolic. They are heechmutting! And that with as much zest as a party of 
school-children starting out with haskets and pails on a holiday. Watch them now! What clumsy work they make of it, trying to cling to the beechmut bur and get the nuts out at the same time. It is a pity the chichalee can give them a few lessons: They might hetter have kept to their tree trunks. But they persist, and after tumbling off from several lour's, finally snatch out a nut and fly off with it as calmly as if they had been dancing about among the twigs all their days. Away they go till they come to a maple or some other rough-barked tree, when they stick the nut in between the ridges of the bark, hammer it down, and then, when it is so tightly wedged that the slippery shell camnot get away from them, by a few sharp lows they hrotch the nut from the tree! Through my glass I watehed a number of them this fall, and they all worked in about the same way, though some of them werlged their nuts far into cracks or holes in the body of the tree, insteal of in the bark. One of them pounded so hard he spread his tail and almost upset himself. The fun was so great a downy woodpecker tried it, and of all the big school-boys! The excitement seemed to turn his head, and he attackerl a beechnut burr as if he would close with it in mortal combat:

Though without any real song. the nuthateh has a delightful variety of notes. In May his nasal henli-rl, henli-rl. henhi-u, (o)mes through the 
soft green woods as a peculiarly peaceful caressing note, and his soft yang, yang, yang is full of woodsy suggestions. In the last of June I noted the sweet yah-ha of the nuthatch, the same yang, yang, yang, and his nearest approach to a song, the rapid ych-ha, hro-her-hor-ha. In August and September the nasal yonk is sometimes run into an accelerated half song. Thoreau gives the ordinary winter note as quah, quah. and while that expresses the mellowness of the note on some days better than yank, they are both descriptive. But though certain notes may predominate in given months, on a cold January morning I have heard from a flock of nuthatches every note that I had ever heard before at any time of the year. Like the other members of the quartette, the nuthatch nests in holes in trees or stumps while its lightly spotted eg's's, six or eight in number, are laid on a soft, felty lining.

I am often surprised by discovering the nuthatch at work in places where I despair of finding any birds. One day in December the snow-covered woods seemed to have fallen into the silent slumber of a child. Not a breath came to blow the white cap from the rireo 's nest. or scatter the heaped-up) snow that rested like foam on the slender twigs. The snow that had drifted against the side of the tree trumks clung as it had fallen. In silence the branches arched under their freight; the rich ochraceous heech leaves hung in masses under the snow - not a leaf rustled. 
Overhead the twig's, snow-outlined, made exquisite filigree against the pale blue sky. But suddenly, as the woods seemed to be holding its breath, the yank of the nuthatch came first from one tree and then another. A family of them were looking for their dimner in the white forest. If the snow covered the upper side of a branch, they ran along upside-down on the under side; if the south side of a tree trunk was white, they walked, head down. on the north side; and there, too, was the little drummer - a downy woodpecker, flickering from tree to tree - even here, the merry band was finding a place for itself in nature. As I passed on, fainter and fainter came the note of the nuthatch. I looked back through the woods; the blue sky was veiled by snow clouds, but behind them shone the southern sum, pervading them with that wondrous radiance of white light that only a winter sky can show.

\section{XXIX.}

COWBIRD.

THE cowbird is one of the smaller blackbirds. The male has an iridescent body and purplishbrown head and neck. The female has no brilliant coloring, and is decidedly dingy in appearance.

About the size of the kingbird, the cowbird im- 
poses upon its brothers in the same systematic manner. It employs subtle measures, however, and the result of its work is much worse than that of the kingbird. Audubon says, "Like some unnatural parents of our own race, it sends out its progeny to be nursed." Coues says of its habits : "Like the European cuckoo, it builds no nest, laying its eggs by stealth in the nests of various other birds, especially warbler's, vireos, and sparrows; and it aplears to constitute, furthermore, a remarkable exception to the rule of conjugal affection and fidelity among birds. A wonderful provision for the perpetuation of the speries is seen in its instinctive selection of smaller birds as the foster-parents of its offspring; for the larger egg receives the greater share of warmth during incubation, and the lustier young cowbird asserts its precedence in the nest; while the foster-birds, however reluctant to incubate the strange egg (their devices to aroid the duty are sometimes astonishing), become assiduous in their care of the foundling, even to the neglect of their own young. The cowbird's egg is said to hatch sooner than that of most birds; this would obviously confer additional advantage."

The birds upon which the cowbird imposes sometimes build a second floor to their houses when they find the big stranger egg in their home, and a case is given where even a third story was built. The cowbird spends a large share of 
his time among the cattle in the pastures, so earning his name.

With the cowbird, our pigeon-hole for "blackbirds, orioles, etc." No. 3 , is as full as we shall make it. There are seven birds in it - the boloolink, cowbird, red-winged blackbird, mearlow-lark. crow blackbird, and oriole. Comparing them for a moment with the lower orders of birds we put away in the drawer- the chimney swift, partridge, humming-bird, cuckoo, woodpeckers, and kingfisher; and then again with the other families of perching birds we have had - the flycatchers of No. 1, the finches and sparrows of No. t, the barn swallow from No. 6, and the chickarlee and nuthatch from the "muthatches and tits" of No. 12, we shall see how clearly they stand out as a group.

Perhaps it will be well to summarize their common characteristics.

Blackbirds, orioles, ete. (Pigeon-hole No. 3.)

Birds that live in the meadows.

Meadow-lark.

Bobolink.

Birds with much black in plumage. (Compare with sparrows.)

Crow blackbird.

Red-winged blackbird.

Cowbird.

Bobolink.

Oriole. 
108 BIRDS THROUGH AN OPERA-GLASS.

Birds whose general build is compact but slender, and by whom the claw is used for holding fool. (Compare with robin and sparrows.)
Oriole.
Crow blackbird.
Red-winged blackbird.

Birds in which the females are smaller than the males.

\author{
Red-winged blackbird. \\ Cowbird. \\ Meadow-lark. \\ Crow blackbird.
}

Birds with long straight bills. (Compare with swift, chickadee, finches, and sparrows.)

Crow blackbird.

Red-winged blackbird.

Meadow-lark.

Oriole.

Birds that walk instead of hopping. (Compare with flycatchers, sparrows, ete.)

Crow blackbird.

Red-winged blackbird.

Cowbird.

Meadow-lark. 


\section{XXX.}

\section{WHITE-THROATED SPARROW.}

Thot $\mathrm{an}$ the white-throats nest in the Adirondacks and other dense northern forest regions, they come to us for only about a month in spring and fall. In Northampton, Massarchusetts, I have heard their clear spring whistles, -

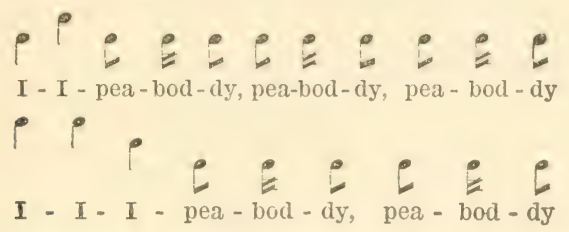

coming from the wooded bank of Mill River, from the low bushes of the fields, and the undergrowth of the woods on the outskirts of the city ; and in the fall have seen them in front of the houses scratching among the leaves under the evergreens of Round Hill.

The first intimation I had of their return this fall was in the clearing one day, when I foumd two of them sitting atilt of a blackberry bush in front of me. As one of them sat facing me and the other had his back to me and only turned to look over his shoulder. I hat a chance to note not only the white chin and ash-gray breast but the black striped chestmut hack and the pretty fire-striped (rown, whose central grayish line is enclosed by 
two black lines, bounded in turn by the whitish line over the eyes. While I was watching them their attention was diverted hy the barking of a gray squirrel in the woods. but they seemed to listen to him as they had me. with quiet interest, little more.

A large flock of them stayed here for about a month, keeping always near the same spots, - a brush heap), an old (lead tree-top, by which water and grain were kept for them, and a raspberry patch a few rocls away. From the raspluerry patch would come their quarrying note that Mr. Bicknell speaks of, the peculiar chelinli that gives the sound of a chisel slipping on stone, and which, when coming from a flock at a little distance, gives the effect of a quarry full of stone cutters. As I went through the patch they would fly up from among the bushes, some uttering a little surprised chree, some calling cheep as they flew noisily by, while others clung, crouching close, to the side of a stem, looking back to see who I was.

The small slate-colored snowlinds, the juncos, were with the sparrows more than any other birds; but the oven-lind, whose premises they had invaded, looked down on them with mild curiosity until it was time for her to go south; and later, a family of chewinks chased them off the fence by way of turnabout justice, though you are tempted to feel that the white-throats need little punishment. They have none of the petulance or arbitrariness 
of chippy, but with the sweet temper of the song sparrow, these larger cousins have a thoughtful bearing that harmonizes with their spring song, which is tinged with sadness, like the melodious call of the bluebird.

One morning in september, not finding the white-throats in the raspluerry-pateh, I went on to a circular opening near the edge of the woods just south of it. The sunlight streaming down through the half Indian summer haze and melting into the soft lights and shadows of the surrounding green woods, gave a mystic loveliness to the spot. A delicate white binch stretched up, sumning itself: a maple trunk stood in sharlow with one spray of a drooping branch dipped in the emerald sun dye : the red autumn leaves lodged here and there seemed to be shaken out of sight by the green bushes, but a breath of fresh wind mumured that summer was past and - was it a footstep)? No: It was an army of little autumn pedestrians! A happy host of white-throated sparrows, hopping about on the groumd under the bushes. Busy and fearless, their footsteps pattered on the leaves. and they sometimes came within two or three fecet of me without taking fright. A chipmmunk soudderl through the bushes after his playfellow without startling them. From every sille came the happy chee-ree; a coloweb shimmered in the sunlight. What if fall were coming? It brought these little friends of ours! 


\section{XXXI.}

\section{CEDAR-BIRD ; WAXWING.}

Tre cedar-birds go into pigeon-hole No. 7, the place for "the waxwing's." etc., and when you have examined them you will feel that they deserve a cubby-hole of their own. In spring and fall they are found in flocks, often of fire or seven, but you will be likely to overlook them if you are not consciously watching the linds. They are rather shy, and are slender birds, a little smaller than a rolin, with inconspicuous coloring, and, moreover, have no song to attract your attention, - nothing but a lisping note and a faint whisthe that sounds as if they were drawing in their breath. But they are about. and in .June will probably nest in the nearest orchard, and eat canlier-worms from the village trees.

When you find them you will be repaid for your troulle. By the law of compensation. discussed hy Darwin under the head of Natural Selection, their heauty makes up for their lack of voice, while, in the case of the sparrows, plainness is compensated by musical power.

The waxwing's plumage is a soft fawn tone, lit up) by touches of (rolor. Its crest is fawn. but it has a black (hin and a black stripe through the eye, a yellow hand across the end of its tail, and, - most migue external feature of all. which ex- 
plains the name waxwing — a tiplping of a bright red horny substance that looks like sealing-wax on the shorter feathers of its wings, and sometimes the feathers of the tail. How prettily the tipping lights up its dainty coat! It gives the final touches to an artistic costume. But what implesses you most at first sight is the waxwing's crest, and the fact that, unlike the fluffy chickadee, every delieately tinted feather of its shapely body is smoothed into place with exquisite care. The waxwings are the élite of lirel circles, and seem fit companions for the proud oriole and the graceful cathird. But how modest and retiring they seem as they hille away amomg the leaves, silent and self-contained, while the handsome oriole flaunts his scarlet hamner through the ari, hlowing a bugle-note for all the world to hear: and the gaty Bohemian eatbird chuckles at his own jokes, and tells the lilar's all he knows as he idles in the sunshine.

Nuttall relates a curious instance of politeness which he noticed among cedar-birds. One, hava ing caught an insect, gave it to his neighbor, who took it to give to another, he in turn passing it on, till it had gone the rounds of the group betore it was devoured!

The gentle affectionate nature of the reelar-lind has often been commented upon, and naturalists have called attention to the fact that the pretty little birds have even adopted the human symbol 
of tenderness, and are often seen kissing each other. Gumpei Kuwada, the young Japanese observer at Northampton, Massachusetts, has sent me some interesting notes on the subject. He says: "On the 7th of May I saw a very large flock of cedar-birds, Ampetis cedrorum. Two of these were seated on a branch a little distance apart, and one hopperl toward the other and bent down his head and touched the bill of the other with his own bill, then went back to his place; then the second bird went to the first bird and went through the same motions and returned to his place; then the first bird repeated the performance, and so these two cedar-birds went alterniately and touched each other's bills for about five minutes. The action of the two birds was so fumny that I could not call it anything else but that they fell in love and kissed each other. It could not possibly have been a mother feeding her young, because it was so early in the season, and they were in a flock and had nothing in their bills, and their bills were shut."

The redar-birds are not only affectionate in their own families, but sometimes show the most human compassion to stranger birds. Mrs. Martha D. Jones, of Northampton, writes me of a touching instance of their friendliness. She says: "Last summer my sister watched for weeks a rohin's nest in an apple-tree some ten feet from her chamber window. She could see into the nest, 
and day by day watehed the maturing of love and hope and faith till the little ones were fledged. Then eame a sad day when the mother lird was killed, and again a sadder still when the sole provider of the hungry brood was taken. Who should provide for the four little gaping mouths? Must the little ones perish also? Their pitiful cries could be heard in the house, and my sister. tried to derise some way to reach the nest and relieve them. When lo! she was anticipated. The young had been heard, and a pitiful heart had responded.... A cedar-bird came before the day closed and adopted them, fed them constantly for more than a week; brought them safely from the nest and tanght them to fly as though they had been her own." What an example these birds could set the kingbird and least flycatcher !

\section{XXXII.}

\section{CHEWINK ; TOWHEE.}

THE sight of a chewink, even in migration, is a rare pleasure in the Ailirondack region. One October morning when the ordhard trees and evergreens are astir with sparrows, a lig umberbrown bird comes out from the low branches of a Norway spruce. and, showing white tail feather's as she flies, hides away among the low spreading 
branches of a white birch. Just as I begin to question my eyes, she flies into a plum-tree and I recognize the small brown hearl, the short finch bill, — for she belong's in pigeon-hole No. 4, - and the white triangular corner's of the chewink tail.

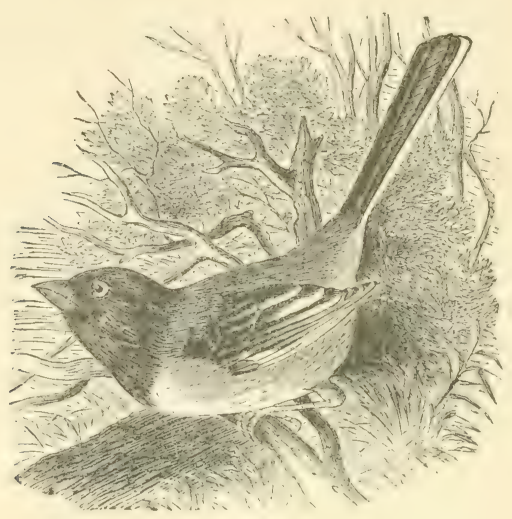

But on the instant she spries me, and away she flies, low over the ground to - I never know where. Had she clapped on a magic cap she could not have vanished more completely. I waste the best part of the morning hunting for her, and the next day begin the search again.

Going along a narrow trail that serves as snowshoe path in winter, in passing a dead tree top I start the usual number of white-throats, and as I turn the corner of the fence into the clearing-behold! - right before me, clinging to the side of a 
raspberry stem and looking at me orer his shoulder, is a handsome male chewink. What a heauty! His batk is hlatek and his sides mateh the (risp) curled beech leaves that color the wood paths in fall. He whisks his tail back and forth, and opens and shuts it as a nerrous beauty toys with her fan, so disclosing the white feathers that border it and the white triangles on the corners. But before I (an prut pencil to note-book he hats disappeared. I spy about in all directions, get down on my knees to peer through the rasplorery bushes, and tiptoe along, ogling all the white-throats that light on the fence - but nerex a ghimpse do I get of him.

Then suddenly he appears on top of a fence facing me; lout as I look down he hops among the ferns, and as I screen myself hehind a tree for a better view when he shall $\mathrm{fy}$ ul again, a low cheree-rh-ree reaches ne, and I see him on the fence several rods away! He looks up to the trees, raising and lowering his (ap), with the odd effect of romeling or flattening his head, and then. deciding in faror of brambles, jumps off into the bushes again.

And so I follow him for three or four hours, trying every (levio to keep) near without letting him take fright, stepping on mosis or walling along the trunks of fallen trees to avoirl the ciackling soumd of the leaver, stopping to listen for his soft cherec-ah-ree, getting down to look through the bare stems of the husles for him, and, if I see 
him as he seratches among the leaves, crouch motionless close to the gromel till I am as full of ('ramps as Caliban. (Once, seering him on the fence, I stand close to a tree and take an old diy golden-rod - curious freak it is too, with axillary Howers all the way up the stem - and hang it from a twig in front of me as a screen and in that way get a good look at him through my glass.

Otf his gruard, he loses the aler't nervous mamer noticed at first, and seems wimningly peaceful and social - but just as I an allowing him all the virtues of the decalogne. he flies at a white-throat that presumes to light on the fence, and drives it off in a temper!

I next find both Mr. and Mis. ('hewink by the corner of the fence where grain and water are liept for the hirds. and when Mr. Chewink is not chasing after white-throats, they husy themselves humting among the leaves. Near by a partridge sits motionless on a limb, so close to a tree she seems part of it. So much for heing in the landscalpe! I take Madam Partridge's hint, and perch myself on the fence with my back to a tree that stands by it; and, thanks to the deviee, when Mr. Chewink comes. after hoppling about unconsciously just in range of my glass. he flies up on an arching blackloerey stem only a few feet from me and sings softly to himself for sereral minutes without ever noticing me!

After about a week a storm came that drove 
the chewinks south, and I searched through the rasploerry pateh and wandered through the woods alling to them in vain. But one day after the middle of the month I fomd another male eating the grain. He s'ratched among the leaves in full view, ruming at them with a queer energetic motion, tossing them up behind him. I harl a long conversation with him, hut though he answered all my remarks in a very friendly way, he looked cold, and talked in rather a pensive strain, and I saw no more of the family that fall.

\section{XXXIII.}

\section{INDIGO-BIRD.}

Ix a paper in the ". Audubon Magazine," Mr. Ridgway has shown what a mistake has heem made in depreciating our Anerican songsters. With equal justice an article night he written, calling attention to the brilliant plumages of many of our northern lirds. The purple grackle, oriole, bluebird, goldfinch, humming-hirel, hatn swatlow, blue jar, purple finch. scarlet tanager, redheaded woodpecker, rellow-throated vireo, and numbers of onr warlhlers would excite wondering delight if they should bear South American or European labels. Indered, among himls as among roadsicle flower's, we need to make it the fashion to appreciate on own national gallery of beantis 
Not the least of om most hrilliant every-day songsters is the indigo-lirel. Only in a poor light is he as dull as common indigo. In the sunlight his coat is an intense, exquisite blue, the shade of which varies as he moves. and is described by Thoreau as "glowing indigo." Mrs. Indigo has a pretty tinge of blue on her shoulders and tail feather's, but if the light is not right to bring this out, the peculiarly warm hrown. which is almost burnt siemna, is enough to distinguish her from the ordinary brown birls that are like her in size and build. Her habit of jerlking her tail from side to side is also diagnostic.

The indigo-bird is one of our most energetic, tireless songsters. He is usually seen on the top of a bush or a tree not more than twenty or thirty feet high: often in the edge of the woods, or in a (chmp) of bushes heside the road, and sometimes in the garden, where his breezy, sumy song shows that he is making the most of all the light and air that are to he had. Blithe and merry in the sunshine, he sings as loudly through the noondiay heat as in the cooler hours.

Ilis romdelay has been syllathified in various ways, but the rhythm and tone may be sugesested

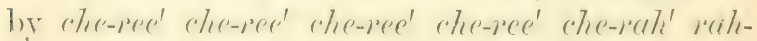
my'. The last half varies greatly, sometimes

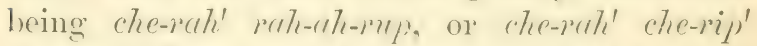
rhempl. Tery often the song ends with an indescribable, rapid flomish of enfused note's. 
This June a pair of indigo-birds built in the edge of the woods only a few rods from the house, but I think they never ceased to regret their temerity. "The nest was a pretty little bunch of dry leaves and grass, and its deep), narrow cavity was lined with hair. It was wedged into the fork of a tiny beech, only six inches from the ground, and not nore than three feet from the carriage drive. The mother would sit quietly when wagons passed, but as soon as she found that I had discorered her nest would fy off in distress whenever I happened to be walking by. Unlike goldfinches and sparrows, the mother nerer got used to me, and to the last suspected me of - I don't know what murderous intentions - darting off into the low bushes with hel metallic rheep, cheep, as soon as she canght sight of me, and almost refusing to feed her babies till I had gone back to the house. Her husband, though somewhat suspicious, conld not share her alarm; he chirped and jerked his tail about, but his anxiety had a perfunctory air.

Earlier in the season I saw a very marked instance of this difference in temperament. I was walking through the edge of a clearing when I scared up a mother indigo-bird, apparently looking for a gool site for her nest. 'She was much excited, and twitched her tail as she flew about crying cheep, cheep. She made so much noise that her husband heard her, and came flying home to rescue her. He did not think either my dog's or 
I looked belligerent, but followed her from limb to limb to be near if we should attack her. It was evident that he did not sympathize with her fears, as he neither cried out nor jerker his tail ; and after he had chased her patiently all over the branches, from one tree to another, and through the bushes, at last he turned toward her on a branch and looked at her as much as to say, -

"Oh! you tiresome creature; why will you be so absurd? Don't you see they 're not going to hurt you?"

His contempt had no effect, however, and - he opened his mouth at her! This threat of conjugal authority subdued her, and at last she meekly flew off into the wools with him. But, like some other good wives, she had her way in the end, and though she followed Mr. Indigo back there several times to look for "empty lots," two or three more scares determined her, and the nest was built elsewhere!

\section{XXXIV.}

\section{PURPLE FINCH.}

THE purple finch is about the size of his cousin the song sparrow. He is as fond of singing in a maple or an erergreen as chippy is of trilling on the lawn. and the result is much more satisfactory, although he does not sing as well as the song sparrow. 
Now and then you catch at sweet liquid note, but for the most part his song is only a hright warble, without heginning or end. The song sparrow, you know, begins, strikes his mper note three times, and then runs down the scale, finishing off usually with a little flomish ; but the purple finch seems to sing in cincles, without much musical sense - nothing but a general feeling that the sum is warm and bright, and there are plenty of buds and seeds to he found near by. Thoreau puts the somg in syllables as - u-twitterwitter-ritter-mee, a-ritter-utiter-ree.

The song is at its best when our pretty finch is in love. Then it has more expression and sweetness and resembles the whisper song of the robin. And when he bows and dances before the little brown lady he is trying to win for his bride, his pretty magenta head and back, his rosy throat and white hreast, with his graceful ways and tender song, make him an attractive suitor. The brown-streaked, sparrowy-looking little creature who seems to ignore him at first, can scarcely help) feeling Hattered by the derotion of sur.h a handsome cavalier, and you feel sure that his wooning will come to a happy end.

Like the waxwings, bobolinks, white-throated sparrows, blue jays, goldfinches, and swifts, except in the nesting seatson, the purple finches ane generally found in flocks. their farorite haunts being woods and orchards. 


\section{XXXV.}

\section{RED-EYED VIREO.}

Arroxg the songs that come through the open window in summer, there is one I hear when the midday heat has silenced nearly all the others. It comes from the upper branches of the trees alout the house, and is a preoreupied warthle of three loud, guttural notes, giren with monotonous variety. In rhythm it is something like he-ha-reluce or he-hat-2cher, or, again. he-hrr-lh hip in rising inHection, and he-her-nthee in falling arlence.

If I go out and foum my glass on the dullcolored bird that mores along over the branches inspecting the leaves in such a husiness-like way, I discover it to be an expuisite little ereature. tinted more delicately than the waxwing, lut with much the same glossy look and elegant air. It is a slender bird, about lonlf as large as a robin. Its hack is olive, and its hreast white, of such tints that when the sunlight is on the leaves our vireo is well disguised. for its back looks like the upper. side of the leaf. and its hreast like the under side with the sun on it. If the hird consirterately flies down into the lower branches, as it turns its head to one sicle, I can make out its ash-colored cap and the lines that border it. - first a black one. then a white, and below that another black line. running through the eye. 
If its search among the lower luranches is successful it rums along the length of a limb, holding its worm out at bill's length, shalking it over the limb as if afraid of cloplong it before it is in condition to swallow.

But although one becomes attached to the cheery bird that sings at its work from morning till night, in park and common, as well as about the country house, the hest way to know it is to follow one of the family into the edge of the woods where it builds its nest.

Such an exquisite little workman as you discover it to be! It wonder's how the madow-lark and bobolink (an like to nest on the damp ground, and how the woodpeckers can live in a tree trunk, how can they ever keep their habies quiet without a crarlle! The coarse mud-plastered house of the robin fills it with lofty surprise. For its part it usually chooses a lithe sapling that responds to all the caprices of the wind, and from the fork of one of its twigs hangs a dainty linch-bark hasket.

For lining it picks up leaf-hud case's, curving stems of the maple sererls, - wings the childrem call them, - and now and then a spray of hemlock. With the artist's instinct it puts the strips of brown bark next the lining, and keepl:s the shining silvery bits for the outside. Sometimes it puts in pieces of white, crisp), last year's leares, and often steals the sicle of a small wasp's nest to weave in with the rest, while bits of white (ool)- 


\section{BIRDS THROUGH AN OPERA-GLASS.}

weh-like sulostance that look as if taken from cocoons are fastened on for ornament.

What could you have more daintily pretty? Nothing after the four white, delicately wreathed oval egges are laid on the maple wing stems in the bottom.

On such a nest as this, with the tender green leaves to shield her from stray sumbeams, and the wind to rock her gently back and forth. brooding must lose some of its wearisome monotony; and you are tempted to account for the difference between the nervousness of some lird mothers and the contented trustfulness of the vireo.

One day I accilentally surprised a vireo on her nest. Here was a chance to see her red eyes. I leveled my glasses at them and stared with the insistent curiosity of an enthusiast. Nearer and nearer I (rept, and actually got within two feet of the tree before she stirred. Then she flew off with only a mildly complaining whee-ough, and sat down in a tree near by to see what I would do next. But just then I espied a wasp's nest about two feet over hers, and not waiting to see if it was "to let," retreated, wondering at the proximity.

There were a number of vireo families that I was watching last spring, and one of them built so low that by pulling down the end of the branch I conld reach into the nest. One day when I went to examine the engs they had turned into a family of such higyellow-throated youngster's that they filled the nest. 
The mother dicl not seem to be there, so I sat down with my dogs near hy to wait for her. I supposed she was off worm-lumting and would fly batck in great excitement on discorvering the intruders. But all at once, almost over my hearl, I heard a low, "rooning wher-eh! I I turned in surprise, and there was my mother hird looking down at me with all the composume of an old frienrl. If her-2rher-2ellu, she said, as she saw the doges and took in the group' again. As we kept still, and did not offer to molest her children, she sonn hegan looking about for worms, saying tereter-ereter in the most complacent tone as she worked. She would tum her head and lonk down at us now and then with mild ('uriosity: but although I went back to the nest to test her she semed to have perfect confidence in me, not showing the least alarm.

Afterward I heard the vireo song from her, and concluded that she was the futher of the family, left on guard while the mother was taking her rest. I thought perhap)s that aneounted for some of the indifference, hut after that, when I went to see them. I formd both old birds, and always met with the same trustfulness. Indeed, they would talk to me in the most friendly manner, answering my broken bird talk with gentle sympathetic seriousmess that said very plainly they linew I meant well, and what a sweet winsome sound it had, uttered in their low carressing tones ! 
To their enemies, howerer, these beautiful birds are neither' gentle nor ('onfiling. Last June, as I was watching a chestnut-sided warbler from the undergrowth near a vireo's nest. I heard a great commotion among the thrushes and vireos, and hurried out of the cover to see what was the trouble. I heard a low complaining croon from one of the vireos, and looking up saw, to my surprise, a gray sereech owl flying hlindly alout among the branches. After a little he stumbled upon a dead limb and sat lown, trying to feel at home. But the vireos were crying ominously liray. lirec-lireekiree-liree, and when he thought how they had darted down and snapjed their bills at him as he came along. he edged measily over the branch. Just then my dog ame rumning noisily through the dead leaves under the tree. That could be coming next! The scared, awkward owl turned his head orer to one side and strained his higeyes to see. Ilis ear's stood mp, and his pupils grew bigger and higger with fright. He looked like a great booby entrapped by a practical joke. But this was too serious. Thlat with a dozen vireos and thrushes threatening him. some wild animal or other mensing about at the foot of the tree, and the pair of hige glass eyes almost as large as his own. through which another mysterious oliject was menacing him. No owl could bear it! Away he flew, as fast as his blundering wings could flap), followed by the angry vireos, who saw him well 
out of their neighborhood before they let him alone.

The next dlay I scared up) the foolish fellow again, in the same place, and found that the nearest vireo's nest was gone! Not a tracee was left, nothing but one feather! Had he taken his revenge in the night? The trees refused to tell tales, and I had to he satisfied with giving him such a stare as would lieep him away in future.

\section{XXXVI.}

\section{YELLOW-THROATED VIREO.}

Tre name of this heautiful hirc calls up college days, for my first memory of him is a preture of one of the fairest May mornings upon which a Connecticut Valley sun ever rose.

Dandelions were just beginning to dot the tender grass, and the air was full of busy trarellers stopping on their northward journey to see the beantiful old New England town that the birelvoiced efenny Lind christened the "* paradise of America." Earger for a sight of the stranger's, I hid myself under the spreating houghs of an old apple-tree in the corner of an orchard and wated to see what would come.

A purple finch was now gathering materials for her nest where she had lowin copuetting with her' handsome lover not long before, and the catbird 
who lived across the road by the bank of Mill River had flown over to talk with the visitors; while above the rest full and rich came the song of the handsome rose-breasted grosbeak. My cover was a happy thought. Right into the tree over my head came the birds, so busy flitting about the leaves they had little time to look under the branches. And most beautiful of all - though a rainbow of warblers came before I left - was this dainty, golden-throated vireo.

Less restless than the warbler's, he inspected the boughs more thoroughly, giving me at intervals glimpses of his olive back, white wing bars, and hright yellow chin and throat as well as his pretty yellow breast that tums to white below. The-hehe, he sang out as he worked, and I suspect his sharp eyes detected me when he turned his head on one side and peered through the leaves.

How delighted I was to discover, a few weeks later, that he or one of his brother's had gone to housekeeping on the campus! The nest was the first vireo basket I had ever seen, and I well remember the enthusiasm it excited in the other rollege girls. We would go out after brealsfast, watle through the damp grass to the maple from which it hung, and stand looking up at it, admiring the lits of white trimming fastened on at regnlar intervals along the sides, and exclaiming at the beauty of the arohitect watching us from among the leaves, mutil, at last, the tolling of the chapel beell would send us hurrying back up the hill. 


\section{XXXVII.}

\section{WARBLING VIREO.}

Trre warbling is the smallest of the three vireos. Its back is grayish olive, and its breast is tinged with yellow. It may be distinguished from the others by his song.

Dr. Brewer says: "This vireo . . is to a large extent a resident of villages, towns, and even cities. It is by far the sweetest singer that ventures within their crowded streets and public squares, ... and the melody of its song is exquisitely soft and beautiful. It is chiefly to be found among the tall trees, in the vicinity of dwellings, where it seems to delight to stay, and from their highest tops to suspend its pensile nest. It is especially abundant among the elms on Boston Common."

By reason of their dainty coats and shapely forms, their pretty ways and their repose of mamner, the vireos renind one most forcibly of the waxwings.

Birds naturally group themselves by oceupation, and, as a Darwinian corollary, by coloring. The sparrows spend most of their time on the ground searching for seeds, and are protected by their earth-colored suits; the woodpeckers live clinging; to tree trunks, and many of them are disguised by their likeness to the bark; the flycatchers take their living from the insects that swarm in the 
air', and their dull color's serve as non-conductors of attention; while the vireos, who live on measureworms and similar morsels, are so exclusively devoted to foliage that they might well be called leaf-birds, and their tints harmonize strikingly with their habits. They may well be known as "greenlets."

\section{XXXVIII.}

OVEN-BIRD; GOLDEN-CROWNED THRUSH.

WE have had the loud rattling trill of the yellow hammer, the alarm of the kingfisher, and the fine, shrill trill of the chipping sparrow, but now we come to one that differs from them all. Mr. Burroughs has aptly described it by the word terch-er. It seems to beat upon the air, growing louder and louder, increasing in intensity, volume, and rapidity until the end, like

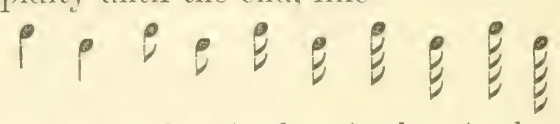

teach-er, teach-er, teach-er, teach-er, teacher

Ordinarily the trill is your clue in looking for the oven-bird. When you hear it close at hand, and fail to see him on a tree, look carefully under the bushes on the gromul. If you see a bird the size of the white-throated sparrow, tossing the rlead leaves aside with his bill and scratching them 
up, less like a chewink than like a hen, you have probably found your friend.

His olive-green back makes him inconspicuous when he is among the leaves, and the thick brown spotting on his white breast serves as a disguise when he is on the ground. If you are fortunate you will discover his orange-brown crown, enclosed by two black stripes that converge towarl the bill.

Like the partrilge, the crow, the blackbirds, and the meadow-lark, the oven-bird is a walker, so that you can distinguish him at a glance merely by his leisurely dignified gait, — it is such a contrast to the hopping of the chewinks and sparrows.

The leaf-house from which the oven-lird gets his name varies in its roofing, but the first nest I ever found may be taken as a type of the commonest style of architecture. It was a bright morning in June, and while walking through the edge of a grove of young maples a brown shadow started u1) from under my feet and disappeared in the woods. On looking down beside a blooming Solomon's seal, I saw what at first glance seemed to be a bunch of dry leaves, - one of the thousand pushed up by mice or crowling spring flower's. But the hint given by the fleeting sharlow could not be ignored, and I stooped down to examine the bunch. I felt it over eagerly, - one, two, three sides, no opening; the fourth, my fingers 
slipped in, - it was the unique orem-bird's nest I had been hoping to find erex since I was a child.

In an instant I was on hands and linees peering through the mysterious doorway. How interesting! There lay five expuisite egg's, their irregular brown speckles centring in a crown ahout the larger end. What a wonderful builder the little creature seemed! His arched roof was lined so smoothly with soft dry leaves it suggested a fretwork ceiling. What a tiny palace of beauty had this golden-crowned queen of the thrushes ! What mystery that bunch of laves held! The little brown lady might have been sitting at the mouth of a fairy cave.

The next day I fomd three of the egogs hatched, and such absurd-looking nestlings had well been taken for bird gnomes. The seemed all mouth and eyeball! Small red appendages answered for wings, and tufts of gray down on the skin did for a coat of feathers. Even when feelsy throwing up their heads and opening their lig yellow throats for worms, the lirds' eyes were closed so fast they had an uncammy appearance. The same day I had the good fortume to stumble upon another nest. This was essentially the same, though built more of fine roots.

The ingenuity of the builder's is shown by a derice which puzzled me oreatly in my first nest. I made several visits to it. and when the little ones had flown, fouml that the grass around the 
mouth of the nest had been pulled together, so as to leave only a round hole just large enough for the bird to go in and out. For some time I was at a loss to account for it, but I had noticed from the outset that this bird acted peculiarly. On

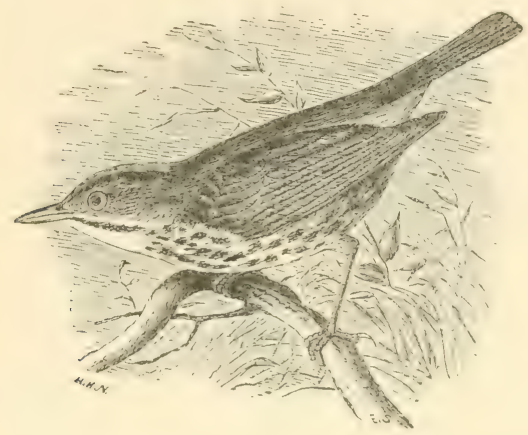

none of my visits had she uttered a note or come near me, while the other mother oren-birds always began smacking their bills and flying hither and thither the instant I appeared. Perhaps this mother was more thoughtful than the others, and considering their clatter dangerous, went to the other extreme.

The most terrified oren-hird that I have ever seen I foumd on a densely wooded hillside in the same woods. Fine began her smarking as soon ats we came in sight, but although we hunted calefully for the nest we could not find a trace of it. Tre sat down on a log and waited for her to show 
it to us, but that did no good. She did confine herself to a radius of about three rods, but selecting saplings at extreme points flew from one to the other as she inspected us, all the while wagging her tail nervously up and down and keeping up the monotonous smacking.

Finding her as incorrigille as the mosquitoes, and realizing the approach of the dinner hour. my friend and I set out for home. But in our case the gods favored the cowardly, for, as we were brandishing on maple twigs in the faces of pursuing punkies and mosquitoes, we suddenly started up the little family we had been hunting for.

They ran out from the leares under our feet, scudding off in all directions. My two dog's pounced after them, and we flew in terror after the dogs, but Balder's big jaws had nearly engulfed them before we had dragged him off. In the midst of the confusion the terrified mother flew to the ground and hegan trailing in a pitifully excited way. She spread out her wings and tail, dragging them along the earth as if helpless. On finding that we would not aceept that decoy, and seeing that her little ones had hidden away under the leares, she tried another plan and walked once slowly back and forth for about a rod on the side away from her young. Haring, as she supposed, completely diverted our attention by these imaginative ruses, as the dogs were perfectly 
quiet, and we had not moved since the first alarm, she made a detour and risked an examination of the place where the little birds harl disappeared.

In watching the oven-bird $I$ have been surprised to find how irregular individuals are in their time of nesting. On June 11 I foumd a family of fullgrown young being fed in the branches of a maple-tree. The same day I found a nest full of egg's. June 12 three of these egg's hatched, and I found a nest of young a quarter grown. June 13 I found the family that I have just described well out of their nest. These could hardly have been first and second brools, as they were in all stages of development. This same difference I have since found in the nesting of robins, vireos, chipping birds, song sparrows and others.

When I consiclered myself well acquainted with the oven-bird and its notes. I was much surprised to be told that it had a beautiful song distinct from the usual trill. The trill seems to be used for all its commonplace thoughts and feeling's, but, as Mr. Bicknell says, “on occasion, as if sudden emotion carried it beyond the restrictions that ordinarily beset its expression, it bunsts forth with a wild outpouring of intricate and melodious song. This song is produced on the wing, oftenest when the spell of evening is coming over the wools. Sometimes it may be hearel as an outburst of resper melody carried above the foliage of the shadowy forest and descending and dying away with the waning twilight." 
138 BIRDS THROUGH AN OPERA-GLASS.

Mr. Bicknell speaks only of the two songs, but I have heard the two combined. The outbreak of high, rapid, confused notes being interlarded with the low-pitched conversational trilling tearf' er, teach'er. By increasing the confusion, this adds greatly to the effect of excitement spoken of by Mr. Bicknell. Though most common at evening or in the night, I have frequently heard this medley in both morning and afternoon. The rhythm and rolume of this interesting song in its simplest form may be suggested by the syllables whee'he, whe'he, whee'ha, he' he' ha, increasing' in volume toward the middle, and unlike the ordinary trill, diminishing in intensity again at the close.

\section{XXXIX.}

JUNCO; SLATE-COLORED SNOWBIRD.

EARLY in September you may have found the juncos, companies of little gray-robed monks and nuns, just emerging from the forests where they cloister during the summer months. Most of them nest well to the north, but still there are many that content themselves with the cool mountain ranges of the Alleghanies.

If they build in your locality, as they do here, their habits, like those of the chickadee, are greatly changed in summer, and you will take more than one casual walk through the woods be- 
fore you discover them. They are no longer in flocks, but in pair's, and I consider myself fortunate if I get a timid look from one from among the dead branches of a fallen tree top.

Early last May I was delighted to see a pair. on the edge of the raspberry patch, but though they inspected the recesses of a pile of hrush, seemed greatly interested in the nooks and crannies of an uptumed root, and reviewed the attractions of a pretty young hemlock that stood in a moss-grown swamp on the border of the patch, I suspect it was only a feint; and when they came to the grave business of house choosing they followed family traditions and built under a stump, in a hole beneath the root of a tree, under an overhanging bank, or somewhere else on the ground, with a natural roof to keep off the rain.

At all events, they left the rasploerry patch, and with the exception of one or two that I heard giving their high-keyed woodsy trill in . Tune, that was the last time I saw any of the family there until fall. Then they came out in time to meet their cousins the white-throats, and stayed till after the first snows.

Like the sparrows, waxwings, blackloirds, swallows, blue jays, swifts, and others, the juncos live in flocks when not nesting. One day in September I found a number of them gathered around an old barn, some sitting quietly on the hoards and sticks that lay on the ground, and others, as 
becomes inhabitants of No.4, hopping about picking up seeds.

Another day they and some white-throats were by the side of the barn eating grain scattered at the threshing. Not content with what they could find there, some of them flew up on the sill of a small window, hopped along, and actually (lisap)peared in the dark barn.

As the weather grew colder they came, as they do every spring and fall, to see what they could find to eat by the side of the house. Here, where they find only friends, they raise their heads with quiet curiosity when you approach, and seem notably gentle, trustful birds; but it is said that they show much caution as well as intelligence in eluding their enemies, and are anong the most difficult birds to snare.

\section{XL.}

\section{KINGLETS.}

Do you know these dainty little birds that visit us twice a year? Some hright September morning you wake up and find them flitting about the apple-trees, and know that fall has come. But they tell you the farot in such a breezy, cheery way that you remember only how glad you are to see them. In April they are back just long enough to sing out "How do you do?" and then are off for the north so that summer shan't catch them. 
How do they look? Well, they are fluffy little things with grayish olive coats and whitish rests that protect them as they flit about the leares as perfectly as the vireo's suits. That is the way I thought of them when I had only a vague idea that one of the family had a golden crest, and the other wore a ruby crown. But one fall, when they came back to the old thorn-apple by the garden, I thought I would learn to know the cousins apart.

That morning one little fellow had the tree all to himself. And what a queer gnome he was! A fat ball of feather's, stilted up on long, wiry legs, with eyes that, though set odlly enough far back from his bill, were yet so near together they seemed to prevent his seeing straight ahead. He would flash one eye on me, and then jerk himself round and flash the other, scolding in the fumniest way with his fine chatter. I could not see that he had any crown at all, and so was as much puzzled as ever to decide which kinglet he was.

He and his friends were here by themselves about two weeks, working industriously all the while - dear little brownies - to clear our mountain ashes and apple-trees of inser'ts before leaving' us. I came to know them as far off as I could see them by their restless bluebird way of lifting their wings and twinkling them in the air as they hunted through the branches. And how they did hunt! As the kinglets live among the leaves, 


\section{BIRDS THROUGH AN OPERA-GLASS.}

they adopt the tints of the vireos, though they are as little like them as the fluffy chickadee is like the vaxwing in build or temperament. The vireos walk sedately down the length of a branch, calmly turning their heads on one side to peer under the leaves for their measure-worm; but the kinglets! - clambering up a limb, turning from one side to the other, with one big eye always close to the bark staring for insects; fluttering under a twig like a humming-bird, and then eatching hold upside down to pick off an insect; flitting about from branch to branch; stopping a moment to eye me inquisitively, and then hurrying on with their work - the restless pigmies seemed most unvireo like.

At the end of two weeks I had seen no kinglet crown of any kind. But one day I had a surprise. Hearing a faint note from a Norway spruce I looked up and saw a kinglet, but - what was it? Instead of being one of my gnomes, he was the most human, every-day sort of a bird, with a naïve interrogative air that might have argued him an American. Then his tiny. stubby bill stuck out from his lig head with such a pert, husiness-like air it gave my idea of kinglets another shock. What was he? Could I have been wholly mistaken? TV as my elf no kinglet at all - was this the kinglet? Such a crown: I had comforted myself for my gnome's lack of crown hy thinking that it was concealed like the king- 
bird's, but here, - how could such a crown as this ever have been hidden? Why, the black lines came way down to his absurd little bill, and the gold between them was plain enough to be seen almost as far off as the bird himself.

I came in bewildered enough, but the moment I saw DeKay's plates I understood it all. This was the golden-crowned, and my pigmies were the ruby-crowned kinglets. After that the two kinds were here in great numbers for two weeks, and before the rubies left I surprised one of them into showing his beautiful scarlet crown. The rubycrowns went as they had come, two weeks in advance of the goldens.

When they were both here I used to stand under the apple-trees and watch them. Sometimes there must have been twenty in one tree. They were very tame, but rarely found time to look at me.

Seen together the golden is appreciably the smaller; his legs look shorter, and he is not so plump, - appear's more like an ordinary hincl. His back is grayer than the ruly's, and when his wings are crossed over it you get an effect of bars near the tips. Mr. Golden-crown has a concealed patch of carlmium orange in the centre of his rown, but his wife is content with the plain gold, and the children often show neither black nor gold. The goldens seem to have less of the wild bluebird habit of lifting their wings when lit, but 


\section{BIRDS THROUGH AN OPERA-GLASS.}

they hang mpside down eren more than the rubies, often flying up from one spray to light upsicle down on the one above. The goldens lave a business-like way of getting under a leaf and picking off the insects one after another as fast as their tiny bills can work. Their song is said to be inferior to that of the rullies, which is considered a ten-days' marvel coming from such a tiny bird.

\section{XLI.}

SNOW BUNTING; SNOWFLAKE.

Turs is the true snowlind. and though it belongs in the same pigeon-hole - that of the finches and sparrows - it can never he confoumded with the junco. The monastic juncos are closely shrouded in slate-gray roles and cowls, only a short under robe of white being marked off helow their breasts. The snowflakes, on the other hand, as their name suggests, are mostly white, although their hacks are streaked with dusky and black.

The jumcos come about the house in spring and fall, and during the early snows. but the snowlirds, timid and strange, fly over the fields and are associated with the wonderful white days of a country winter, when the sky is white. the earth is white, and the white trees how silently under. the wand of winter till they stand an enchanted snow forest. For, as the flakes drift through the 
air, the snowbirds, nindulating between the white earth and sky, seem like wandering spirits that are a part of the all-pervading whiteness. Thoreau says, "they are the true spirits of the snowstorm. They are the animated beings that ride upon it and have their life in it."

Mr. Allen, in speaking of our winter birds, says: "The beautiful snow buntings when whirling from field to field in compact flocks, their white wings glistening in the sunlight, form one of the most attractive sights of winter." He adds that they are the "bad weather birds" of the superstitious, as they usually appear mysteriously during snowstorms and disappear in the weeks of fine weather. He says: "Colil, half-auretic countries being their chosen home, they cnly favor us with their presence during those short. intervals when their food in the north in fields is too deeply buried; and heing strong of wing and exceedingly rapid in flight, they can in a few hours leave the plain for the mountain. or migrate hundreds of mile's to the northward."

Late in Derember I have seen a flock of them flying over the meadows with the rhythmieal undulating motion of their cousins the goldfinches, twittering ter-rolee, ter-rolee, ter-polee as they went. Now and then they would light for a moment to pick at the seeds appearing above the snow, but soon they swept on toward the nortin. 


\section{XLII.}

\section{SCARLET TANAGER.}

LIKE the vireos, the scarlet tanager is asso. ciated with green tree tops; but if you ask just where you will see him, it is hard to answer. In Northampton, I remember finding him in three quite dissimilar spots.

The bird of Paradise has become a familiar sight in our museums, but the good people of Northampton follow Dante and see "Paradise" itself before they die. "Purgatory" is there, too, for warning, and the river runs between the two abodes! They lie just outside the town, and if you could get some kindly spirit to guide you, they would surely seem well named.

"Purgatory" lies barren and desolate, strewn with sand and stones on which the sum beats down as if with intent to torture imprisoned souls. Opposite stands "Paradise," a wood of wondrous beauty, - a true elysium for the immortal spirits of lirds and flowers! In its heart is a grove of musical pines, whose brown, pineneedle carpet is garlanded with chumps of ferns. Close to the river's edge, reaching their branches low over it as it narrows to a stream, the maples and birches offer cool green shade when the sun is parching the banks of "Purgatory"; and in autumn, when the bare sand and stones grow cold, 
the leaves of "Paradise" burn with the tints of sunset.

On the desolate margin of "Purgatory" you rarely see a human face, unless that of some poor soul-tormented lumatic who has strayed from the asylum on the hill. But in "Paradise" you meet groups of merry children, college girls gathering wild flowers, and all the town in gala-day attire.

This is the hamnt of the birds, and here the Smith Audubon Society has gathered about Mr. Burroughs, listening to his interpretation of the chippering of the swifts that circle far overhear ; hearkening with him to the yellow hammer's cries, and watching the happy goldfinches, busy in the button-wood tops. Here each level has its bird from the leaves, the oven-bird sends up his crescendo; from among the bushes comes the quarrying note of the white-throats; low on the houghs of the trees the thrushes sit wrapt in meditation: in the top of a sapling the indigo-bird sings of the white violets beneath him; from the hemlocks and pines come the screams of the blue jays: over the river the kingfisher flies, somnling his alarm on the wing; and high orerhead the soaring hawk circles in silence.

One spring morning when we were in one of the most beautiful spots of all Paradise, where a tiny rill spreads out orer the sand, bathing the roots of the bright green grass and the blue forget-me-nots, a true hird of Paradise (amme flying 
over our heads, and uttering a loud chuch ah, hid away in the leaves. It was the scurlet tanager, the bird of glowing coal, whose brilliancy passes wonder. His black wings and tail seemed only to intensify his flaming coat, which literally dazzled my eyes as I looked at him. Little marvel that he takes pleasure in the green leaves! and chooses a wife - in most " natural selection" who is also his complemental color !

But how could Madam Tanager ever live with such a fiery husband if her eyes did not find relief in her own greens? Even then it would seem that she had to become accustomed to him by degrees, for in his youth her gay cavalier is relieved by green, yellow, and black. Perhaps even his own eyes get tired, for like the bobolink and goldfinch in the fall he gets out his old clothes and flies away south in as plain a garb as his larly's.

Strolling through Paradise on another day I heard a song that I did not know, and leaving the river edge with its green grass and forget-me-nots, and clambering up the steep hillside where the magic witch-hazel hlooms and shoots its seeds afar, I made my way cautiously to the tree from which the voice came. There, high over my head, was another scarlet tanager. He was evidentìy a young gentleman, for there was still a yellowish streak across his breast. but he sang his woodsy song with all the gusto of an old bass. It is loud and harsh, but in a rhythm that, as it has 
be:n pretinently expressed, suggests the swinging

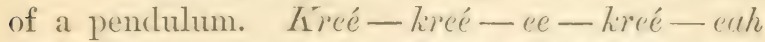
lireé - lireé - ee livéé - eah hack and forth, swinging a little further each time, the whole song often ending with an emphatic chip' chirr.

The third place where I found the tanager in Northampton - and this seemed to be more of a true haunt - was at Fort Hill on the south of the town, where, across the meatows, Mount IIolyoke and Nomnt Tom tower majestically. Here, on a sumny eastern hillsile that looks away toward the Commerticut, the early adder tongues and heyaticas are found, and the scarlet tanager shows a friendliness that becomes the beautiful spot. Close to the footpath I have stood and watched him without exciting the least suspicion or fear.

Here at home I have seen one of the tanagers in an ash that shades the house, and they sing in various parts of our woods. Still, I feel most sure of finding them in a swamp back of the raspberry patch. While a hotanical friend has been looking for rare orchicls among the moss and ferns, I have followed one of the handsome birds through the length of the swamp, punctuating his song with broken bird talk. At times, as I stood on an old mosi-covered log, he would come almost up to me, and then, just as I was admiring his flaming coat, would fly back singing to limself the loud swinging song that seemed to catch new beanty from the rich, cool verture of the swamp. 


\section{BIRDS THROUGH AN OPERA-GLASS.}

Like the vireos, although the tamagers seem to prefer the higher branches and tree tops in singing and hunting, their nest, a "saucer shaped structure," constructed of wiry dearl grass-stems and like materials, "is built usually on a low branch. The egg's are pale bluish or greenish, spotted or speckled with brown."

The tanagers belong in pigeon-hole No. 5, which is marked "tanagers," and is between the "finches, sparrows, etc.," of No. 4 and the swallows of No. 6. Unlike the flycatchers and sparrows the males are brilliant birds, whose plumage varies greatly with the season, and whose plain wives are in marked contrast to them. But compare their unohtrusive ways with those of the catbird, the restless kinglets, chickadees. and blue jays; and their habits with those of the ground-loving ovenbird, the muthatch. snowbird, and partridge, and you will see that the difference lies deeper than color.

\section{XLIII.}

\section{BROWN THRASHER.}

Ix a Massachusetts sand flat, where nothing but sand burrs and low scrubby loushes could flourish, I heard my first thrasher song. There were a pair of birds in a clump of bushes, and we came up within a few yards without disturloing them. Their backs were rich reddish-brown, and their 
breasts ereamy or "buffy white," spotted with brown, while their sides were heavily streaked.

The thrasher's are about the length and build of the curckoos, and before I had seen them near by I confused the two. But you can distinguish between them even at a distance, for the breast of the cuckoos is pure white, while that of the thrash er's is heavily spotted. When you are near enough to discern shates, you see that the rich reddishbrown back of the thrasher is in strong contrast to the dull grayish-brown of the curlioo. While the cuckoo is practically songless, the song of the thrasher is excelled by few of our birds, combining the flexibility of the catbird with the sweetness of the thrush.

The thrasher is said to show much intelligence in choosing the position for its nest. In dry sandy regions it seems to prefer the ground, but if the soil is damp or clayey it builds in bushes; and along river banks in the west, where sudden freshets would swamp a low nest, with notable foresight it secures its nest in trees, sometimes as high as fifteen or twenty feet from the ground.

During migration, last fall, I was looking for warbler's in the rasploery patch one morning before breakfast. When near the edge of the woods I heard the suppressed shreer a gray squir'rel makes when soolding between its tecth. It was so near that I looked down hoping' to atch sight of the impurlent bright ejes, but not a squirrel 
could I see. A flock of warller's came just then to take my attention, and it was some time before I got across the patch. Then I clicl, what was my surprise and delight to find a brown thrasher sitting near the ground on a dropoing bass-wood branch in the midst of a noisy (ompluny of whitethroats. He had evidently seen me. for lis long tail was perked u], his short wings hung at his sicles, and he looked up half appealingly, as much as to say: "Oh dear. what dicl you come here for? - I wish you would n't hurt me! - I sulpose I'd better hide," and so he hopped off to another branch, looked back, saw me still staring. and disappeared.

After breakfast I came back to the spot. Listening alosely I heard the squiryel-like scold that I had noticed before on the opposite side of the patch, and something moving on the leares under the bushes by my side. What was this mysterious reature? Silently I turned toward it and gazed through my glass, almost holding my breath to hear. Again came the noise, and, between the leaves, every few seconds I could catch sight of a brown tail wagging up and down. Suddenly, there it stood in full view, the thrasher ! I could see even his yellow eyes? He was only three or four feet away, but hopped alout quite unconrernedly until I marle myself too conspicuous; then he ranisherl. and I hunted the patch over for another glimpse of him. When I did find him, 
he was sitting quietly on the top of a small stump. He had no objection to make to me then, but when Balder began stalking around among the bushes he stretched up till he made himself look comically like a long narrow-necked bottle, when he took a survey and departed.

\section{XLIV.}

ROSE-BREASTED GROSBEAK.

Just back of the Smith College campus, on the bank of Mill River, where the catbircl talked to himself in the sumy orchard, the handsome purple finch made love to his lady bird, and the cuckoo hid away among the leaves, the rosebreasted grosbeak used to stop before beginning housekeeping. A big maple in one corner of the orchard by the river was his favorite corer, but we have watched him sing quite fearlesily in a small elm on the outside of the orchard, close to the road.

What a beanty he was too! He wore a decorous glossy black coat and white vest, but where his black choker touched his shirt front - was it a beautiful pink rose he had fastened on to artch the eye of his lady? And as he flew past, showing white blotches on his tail and at its base, was that rose powder with which he had tomehexl the under side of his wings? I Iis wife was as good 
a foil to him as her cousins, the plain lirtle purple finch and indigo-bird are to their handsome husbands. She looked decidedly like a sparrow, and had patches of saffron-yellow under her wings, where the male had carmine. Both had heary finch bills. His was yellow, and he scraped it on the side of a branch as a man would sharpen a knife on a whetstone - first on one side and then on the other. Perhaps we should say, men sharpen their knives as birds do their bills, for it is more likely that the birds set the fashion!

The song of the grosbeak is loud. clear, and sweet, with a rhythm like the tanager's. It is a longer song, however, with the rough edges rounded off, and has, moreover, something of the oriole quality. The call note is as characteristic as the chip chim of the tanager. It is a thin, unstealy Fick, and usually prefaces the song.

The nest of the grosheak in "Paradise" was in the border of a thicket, almost within our reach, and when we discovered it, Mr. Grosbeak's big black head and yellow bill were protruding over the edge. Wre could not help laughing at this domestic turn, he looked so out of place; but we liked him all the better for minding the babies while his wife took a rest. 
WHIPPOORWILL. - WINTER WIEN. 155

\section{$\mathrm{XLV}$.}

\section{WHIPPOORWILL.}

In the warm summer twilight as we drive along the bank of Black River, watching the sunset glow facle in the west, and catching its glistening reflection in the water, over the low foot-hills of the Adirondacks on the east comes the big red harvest moon. Then, as we stop the horses to listen, even the siloilant whirr of the locusts' wings and the suldued chirring of the crickets are hushed, for out of the woods comes the loud wild call - whip-poor-vill, whip-poor-will, whippoor-vill.

The whippoorwill belongs to the family of "goatsuckers, swifts, etc.," and so must he put in the drawer where the chimney swift, hummingbird, partridge, cuckoos, woodpecker's, and all the others that did not belong to the order' of "perching birds" were left by themselves.

\section{XLVI.}

WINTER WREN.

One Octoher day when the raspberry patch was astir with fluttering kinglets and warlhlers. and noisy with the quarrying of white-throats, and the muttered excuses and rait, wat of tardy 
crows flying hurriedly over to the caucus in the next woods. I found the piquant little winter wrens bolbing about among the bushes oblivious to everything but their own particular lusiness.

I gave one of them a start as I came on him unexpectedly, and so, on catching sight of a second, kept cautiously quiet. But, if you please, as soon as he got a glimpse of me, the inquisitive brown sprite came hurrying from one raspberry stem to another, with his absurd bit of a square tail over his back, and never once stopped till he got near enough for a good look. There he clung, atilt of a stem, holbling his plump little body from side to side, half apologetically, but saying quip, with an air that assured me he was afraid of no giants, however big! When I hat admired his mottled, dusky vest and his rusty brown coat with its fine dusky harring, and noted the light line over his eye, and the white edging of his wing; and when he harl decided to his satisfaction what I was doing there in the woods, he went hoppling along, under an arching ferm, off to the nearest stump.

When they are out hunting, their tails standing over their backs, their necks bent forward and their straight bills sticking out ahead, these little wrens have a most determinerl air: First you see one examining the sides and top of an old stump, rumning about, dipping down into the hollow, and then flitting off among the bushes, chat- 
tering quipr-quap) as he goes. Then one flies against the sicle of a tree to peck at a promising bit of bark and (damber's several feet ul the trunk to show what a good gymmast he is; and finally one pols ul with a worm in his mouth, shakes it well before eating, and afterwards wipes his bill with the energy characteristic of the active, healthy temper of the whole wren family.

On the twelfth of October the ground was covered with snow, and the woods were so white and still I hardly expected to find anything in the raspberry patch. But walking through I discovered one of the little wrens, as active and husy ats ever. As I stoml watching him he climber into the cosiest cover of leares that a bish ever offered a bird for shelter, and I supposed he would settle himself to wait for the smm. But no! he examined it carefully, turning his heal on oile side and then the other, probably thinking it would be a very nice place for some tender worm, and then flew out into the colle snowy bushes again.

On the twenty-second of the month, when we had had a still heavier fall of snow, and the wrens foumd it ton cold even to take dinner from a golden-rod stem, one of the confirling little birds came to hunt on the piazza right in front of my study window. You should have seen him work! He ignored the (rumbs I threw out for him, lout flitted about, rumning over the shrivelled vines trained over the piazzal, and examining all the 
cracks and cramnies where a fly might edge itself into the moulding. Once he dropped a worm, and you should have seen him come tumbling down after it!

The nest of this brave little bird is snug and warm, made of moss, lined with soft feathers, and lorlged " in crevices of dead logs or stumps in thick, coniferous woods." What a pleasure it would be to follow him north, and study all his pretty ways in the dark forest home, where he furnishes mirth and sumshine all the summer through.

The wren is found in pigeon-hole No. 10. along with his cousins the thrasher and catbird. " Trens, thrashers, ete., is on the door-plate perhaps the catbird is left out because he always takes pains to announce himself. All the household have long bills, and the catbird and thrasher have also long tails, with very short wings, while they all have a piquant way of perking up their tails when startled.

In contrast to the vireos, tanagers. and orioles, these birds spend most of their time in shrubs or bushes ratirer than in higin trees. Different birds take various levels - stories in their out-of-door's house. The sparrows and chewinks live in the basement - on the ground-floor; the wrens and thrashers on the first floor in bushes and shrubs; the indigo-bird on the third floor-low trees; the vireos and tanagers and orioles on the fourth 
floor - high trees; while the swallows and swifts go above all - in the air.

\section{XLVII.}

\section{RED-HEADED WOODPECKER.}

The handsome red-head (an be distinguished at almost any distance by his sharply hlocked "tricolor" of glossy blue-hlack, bright crimson, and clear white. Begimning with his red hearl, the stripes of the French flag are reversed, for the order is not red, white, and blue, but redl. blue (black), and white. Underneath he is pure white. Mr. Burroughs speaks of his flitting about the open woods, "comnecting the trees by a gentle arc of crimson and white?"

When common, the red-headed woodpecker. may be found everywhere, - in the orchards. gardens, fields, and woods, - but in many parts of the comntry he is rather rare. He is an erratic migrant, his residence in any district depending on the nut supply; so that you may not see him for a year or more at a time.

Like the California woorlpecker, the rerl-humls are "hoarders." They have been foumd making a business of storing away beech nuts. They would hide them not only in knot-holes, bretween (racks in the bark, and under strips of loosenerl bark, but also in fence posts, railloarl ties, and 
between shimgles on the roofs of houses; and in several instances when their store-house was full, the woodpeckers would take the precaution to roof it over with a layer of empty hulls, or bits of wood and bark.

\section{XLVIII.}

YELLOW-BELLIED SAPSUCKER.

In the spring the yellow-bellied woodpecker is a mercurial Frenchman compared with the sober, self-contained Englishmen, his cousins, the hairy and downy. They contrast as scarlet and gray. Even their dress marks them. The hairy and downy are robed like grave philosopher's in black and white, the old father's merely doming a red (ap) for dignity. But though the sapsucker has to be content with a mottlerl black and white coat, besides a red ('ap), he wears a crimson frontlet, a hib-shaped piece of crimson satin fastened close moler his chin, and hordering this a circlet of black satin, helow which, and falling to his feet. is his pale yellow robe.

In April and May, especially during courting. the air is full of his boisterous cries. In the edge of the woods, in the orchard. by the side of the house, the excitexl birls flicker from tree to tree. chasing each other about. Sometimes two of them march up opposite sides of the same tree, 
with arching necks and rapid, taunting cries of chucli'ah, chuck'ah, chucl.'ah, chuch'ah, and then circle around the trunk after each other like a pair of hotheaded suitors quarrelling over their lady-love. When they are in a calmer mood their cry, though still emphatic loses much of its taunting tone, and is more like che whee', che whee', che whee', che whee'. They have a variety of call notes, such as liree, lira!y; yah', yah', and lire' ah. all full of spirited emphasis. But their ebullient feelings cammot be expressed in that way; they must needs take to drumming and tinning. I quote from an account of their performances published ten years ago by my brother, Dr. C. I Iart Merriam. It is interesting to note that their habits have not changed in that time. He says : "At this season scarcely an hour passes from daylight to sunset that one or more cannot be heard drumming with commendable perseverance upon the tin-roofs, eave-troughs, or escape-pipes of our house or some of the out-buildings. They strike the tin violently half a dozen or more times, evilently enjoying the sound thus produced, and then rest a few minutes before repeating the performance. Earch woodpecker usually returns to the same spot, and on our roof are sereral patches the size of one's hand, from which the paint has been entirely drummed off. On the escalre-pipe they sometimes follow around a joint, and ly comstant and long-('ontinued pounding so loosen the 
solder that the dependent portion of the pipe falls down. How they manage to cling to these vertical pipes and the nearly perpendicular portions of the roof is a mystery. I have seen both sexes at work on our roof, hut the female does not often indulge in this pastime, and is rarely observed to take part in the boisterous gambols of the males. In the groves and forests where tin-roofed buildings do not abound, the yellowhellied woodpeckers ammse themselves by pounding upon such dry hollow trees and hard resonant limbs as multiply the sound tenfold, so that one (an at a distance readily distinguish them from other members of the family."

The name "sapsucker" is more appropuriately applied to the yellow-bellied woodpecker than to the nuthatch, for instead of taking an oc('asional taste of the sap at the sugar-bush in spring, he spends much of his time riddling live trees with squarish holes, to which he returns to drink the oozing sap and feast upon the insects that gather.

The woodpeckers, I have noticed, all work in about the same way, varying their methods to suit the character of the wood. The only time I ever watched the sapsucker drill a maple he worked like the hairy, first giving a dozen or more quick blows with his head turned on one side, and then as many more with his head on the other sidejust as a carpenter chisels, cutting out a wedge instear of going straight down. After working 
in this way for a time, he seemed to pick out bits of wood - his shavings - and drop them to the ground. When tired working at one hole he would go on to another. The bark was torn from an area of several inches, and this was riddled with holes apparently in process of making. The woodpeckers are not perching birds, and so must be put in the drawer with the kingfisher, cuckoo, humming-birds, and others. Of the five we have had, the yellow hammer is the least of a woodpecker, building comparatively low, having a trill that takes the place of a song, hunting on the ground and fences as well as on trees for his food, and, accordingly, assuming an earth-colored disguise that would be of little use to the other woodpeckers. The sapsucker and the yellow hammer go south for the winter, but the downy and hairy are permanent residents, while the redheaded woodpecker's presence is entirely dependent on the food supply. The sapsucker is the most boisterous of the five - the sombre hairy and downy the most silent. Of them all the redhead is the family beauty.

\section{XLIX.}

GREAT-CRESTED FLYCATCHER.

In spring, when a loud piercing whistle comes shrilling from the woods - one note given in ris- 


\section{BIRDS THROUGH AN OPERA-GLASS.}

ing inflection - I know that the great-crested flycatcher has arrived. There is always an excitement about the event that prompts you to seize your hat and rush out to find him. And a sight of him up in a tree top is worth more than one walk!

By the side of the other flycatchers in pigeonhole No. 1, he stands at the head of the family. What an aristocratic bearing his great crest gives him! And look at his olive coat, his ash-gray rest, and his bright sulphur-yellow lnnickerbockers! You almost expect him to produce wig and shoebuckles! Then compare his manners with those of his plain gray cousins. Do you suppose he could let his wings and his fine rufous tail hang down as the least flycatcher, the phobe, and the wood pewee do? And could such a dignified bird demean himself with the petty bickerings of the kinglird, or the recklessness of the warlike least flycatcher?

The great-crest flies restlessly among the tree tops, uttering his shrill cry, and soliloquizing in a low warbling twitter. He also has a loud short chatter leserved for occasion, and I liave seen him on a tree by the house scolking away with a whee ree.

His nest shows all the eccentricity of genius. It is usually made in a knot-hole, at varying heights fiom the ground. But the strangest thing alout it, and that which distinguishes it from the 
nests of all other North American birds, is the remarkable fact that cast-off suake skins are used in its construction. This is true eren in localities where snakes are so uncommon that an ordinary person may spend a lifetime without finding one of their skins. Surely the birds must possess keen 'yes and much local knowledge of the haunts of the snakes when the shedling process is going on:

Mrs. Tieat tells of a pair of great-crested fly(atchers that built in a birch-house on top of the stable. First, she says, they go to all the birdhouses "scattered ahout on the posts" in the vineyard, but as we would expect of such aristo"rats, choose "the finest establishment on the premises - a three-storied, octagon house, surmounted with a cupolia and spire, with a weather vane and ball attached." Though a pair of bluebirds have kept all would-be tenants away for several years, they offer no resistance to the fly(atchers, who settle in the empty cipola.

\section{L.}

\section{BANK SWALLOW; SAND MARTIN.}

Luke the kingfisher the bank swallow excavates a hole for his nest, and when you are diring through cuts in sand or clay banks you will ofter see the birls pop out of their holes in the sicles and fly off mp in the air. They are the plainest 
of our common swallows, being dead grayish-brown above and white below, with a band of grayishbrown across the breast, so that vanity does not interfere with their underground life.

\section{LI.}

EAVE SWALLOW; CLIFF SWALLOW.

THE cliff swallow is the common swallow that we constantly see on telegraph wires and about barus in company with the barn swallow. It is easy enough to distinguish between them, because the tail of the eave, instead of being deeply forked, is almost square; its back, instead of being glossy steel-blue, is dull blackish, and it also lacks the steel-blue collar.

The nest of the cliff swallow is "a gourd or retort-shaped structure composed of pellets of mud mixed with a few straws and lined with soft feathers, attached to the face of overhanging cliffs or underneath the eaves of buildings."

\section{LII.}

\section{CROSSBILLS.}

In November, 1887, one of the commonest sounds heard on my walks was an odd metallic kimp, limp, Rimp, coming from a flock of crossbills far 
up in the air. They were often so high that I could not see them, and one day several flocks passed over my head, affording only a glimpse of black dots for them all. Their note often came from the hemlocks back in the woods, and on Thanksgiving morning I had the satisfaction of seeing the noisy strangers.

They had come out in the clearing, and lighted near a milk-house, some on a tree and others on the ground. I crept up as noiselessly as the crusty snow would allow, and, screening myself behind another building, watched them for some time. They seemed nervous, for every few minutes they started up simultaneously with a whirr, flew about a few seconds, and then settled down again.

When they were resting, those that were not chattering warbled to themselves in a sweet undertone, but when a new eompany joined their ranks they all began jabbering, and it was a grave question if any of them could hear what they were asking, or their neighbors trying to tell. Then as they broke up into groups and went wheeling about in the air, the glittering gilt deer weathervame on top of a barn a few rods away attracted them, and some of them lit on the horns a moment in passing. Sereral squads of them flew away, and as the confusion decreased the others grew less restless, and twenty or thirty flew down mder the milk-house door and began picking up what they could find on the stones. 


\section{BIRDS THROUGH AN OPERA-GLASS.}

Such a mixture of colors: The old gentlemen were the handsomest, being some shade of red, while their wives and children were olivaceous or grayish. They seemed like a shifting kaleidoscope of colors, as they hopped about busily hunting for food.

Among them were a few of their cousins, the pine finches, and I thought I heard some goldfinches with those that passed over. I got the pretty visitors a basket of grain, and scattered it on the crust for them, but they seemed to prefer cone seeds, for they soon flew orer to the spruces.

Unmindful of the laws of adaptation of which these bills are such an interesting example, the legend accounts for them in its own beautiful way. It has it that the birds tried to pull the nails from the cross, and in doing so twisted their bills in snch a way that wherever they go they will always bear the symbol of their merciful deerl.

The crosslinlls are very erratic in habit, and wander over large areas where they do not remain to build. They nest throughout the coniferous forests of the northern L'nited States and Canarla, and in mountains of the Southern states, notally in North Carolina, Tennessee, and Kentucky.

A curions example of this birt's fondness for salt is recorded hy Mr. Romeyn B. Hongh. An old ice-cream freezer, after becoming permeated with salt, was thrown ont where the crosslills hat access to it, and throughout the winter flocks of 
the birds came to it, like deer to a salt-lick. They were so eager that, in some plares, they actually nibibled almost through the wood until, as Mr. Hough says, the freezer looked as if mice had been gnawing it.

\section{LIII.}

NIGHT-HAWK; BULL BAT.

Just at twilight, above the chippering of the chimney swifts, you will often hear sharp cries that startle you into looking orerhead. Circling in the air after insects you will see large, dark colored birds, with narrow, clear cut, crescent shaped wings and slenter boties. If they come near enough you will catch the white bar's on their wings as they fly rapilly by. If your eyes and glass are both good perhaps you will get a glimpse of their curious great mouths, wide open as they fly; and then the mysterious disappearanee of the swarms of insects that hover in the air will be picturesquely explained.

A study of bills would be as sugentive as interesting. With each group, as we have seen, the form is modifierl to suit the needs of the linds, the woodpecker's have long strong bills for hammering and excavating; the sparrows short stont cones foi seed cracking; the vireos lones slemeler bills for holding worms ; and the Hycatcheres lills 
hooked at the end for holding insects; but perhaps the most extreme cases of adaptation are to be found in those of the kingfisher, hummingbird, crossbill, and night-hawk. In the nighthawk and whippoorwill the enormous fish-trap of

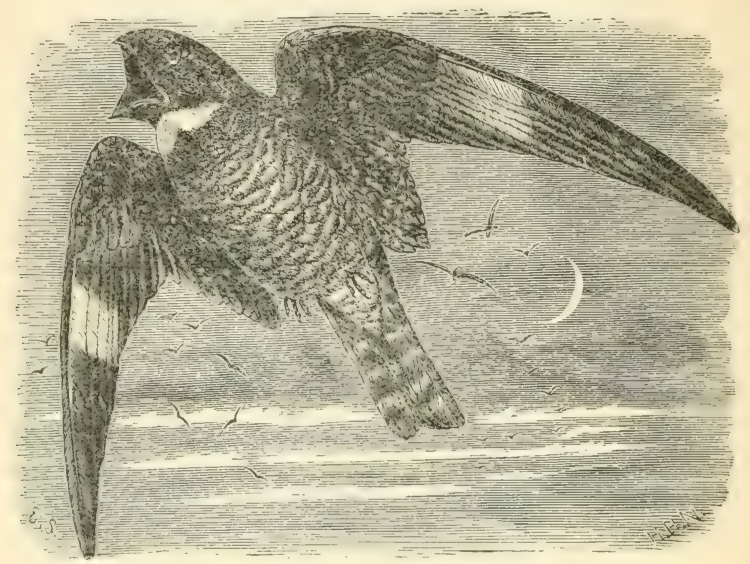

the kingfisher is exchanged for - almost no bill at all, merely a hook and eye for a wide gaping mouth.

The night-hawk and whippoorwill are the most nearly related of the four birds we have from the order" of "goatsuckers, swifts, etc." They are both brown-mottled birds, and are similar in build and general habit. The swifts resemble the nighthawks in having narrow clear cut wings, small bills, and big mouths, but in habit they are almost 
as unlike them as the humming-bird. All four birds have strong wing's, however, and so, as a group, contrast with the sparrows in No. 4, and the wrens and thrashers in No. 10.

\section{LIV.}

GRASS FINCH; VESPER SPARROW; BAY-WINGED BUNTING.

WHeN riding in the country it is well to carry your opera-glass and examine the birds you find on the fences along the road. Sparrows are very common, and if you see one rumning along the fence ahead of you, whose streaked back seems too light for a song sparrow, you will do well to watch him closely. When he flies up, if you see white tail feathers, you know who your friend is at once; the meadlow-lark and the grass finch are two of the commonest of the few white tail-feathered birds. His white breast and sides are streaked, and the marking's on his back almost give the effect of stripes. But the chestnut-brown on his wings and his white tail feathers are enough to distinguish him among the sparrows. His song resembles that of the song sparrow, but while it wants the cheery brightness we love in that, its plaintive element gives it a richmess which the other lacks.

The grass finch is a timorous little bird, and his 
interest in the gemus Homo seems to be confined to the people who pass along the road. These appear to fascinate him, and it is always with reluctance that he flies away before them. A grass finch he certainly is. He nests in the grass, hops about in the grass, lives upon seeds he finds in the grass, and rarely gets much farther away than a roadside fence, or a tree that is surrounded by grass.

\section{LV.}

TREE SPARROW.

THE tree sparrows look much like their cousin (hippy, but have something of the free mountain air and pine-tree atmosphere about them that the domestic chippy lacks.

I find them in spring and fall along the edge of the woods, or in the fields, eating grass seed; and a flock of them spent last April with us, singing with the fox sparrows in the evergreens, and coming about the house in the most friendly manner. Indeed the lordly little creatures quite took possession of the corn boxes in front of the diningroom window, and drove off the juncos with a sad show of temper. I forgare them, however, for I had a capital chance to observe them while they were eating the buckwheat.

Chippy, you know, has a way of crouching close to the ground. The tree sparrows, on the con- 
trary, are ererot, dignified looking hinds, and raise their dark rufous eaps with much more effect than chiply erer does. They differ from him. too, in having the lower part of their backs unstriper, in having rusty washings on the sicles of their ashy breasts, and a dusky spot in the centro of the breast similar to the song sparrow's hreastpin. Their song, though thinner than that of the song' sparrow, is sweet and pleasing.

\section{LVI.}

\section{WHITE-CROWNED SPARROW.}

Derixg migration the white-crowns generally keep by themselves, though sometimes they may he seen in flocks of white-throated sparrows, so it is well to inspect each bird carefully. The crown will enable you to disciminate between them, for' in the white-crown the malking gives nore the effect of a soldier's cap, the loands of clear white encircling the back of the heal. This alds to the clistinguished air of the birl, which, with his (learer grays and browns, his more shapely figure and erect carriage, soon hecome enough to mark him in themselves. For, as the great-resterl Hycatcher orershadows the plebeian phene, the white-crowned sparrow is the aristocrat of his family. But lesides all this he laoks the yollow seen on the heal of the white-thioat, and the 
174 BIRDS THROUGH AN OPERA-GLASS.

median white-crown stripe that separates the two black lines is broader than in the white-throat. His chin, too, is less markedly white.

The song of the two sparrows is entirely different. The white-throat's is a plaintive whistle, both rich and sweet, while the white-crowned has a comparatively low, commonplace song, something like -

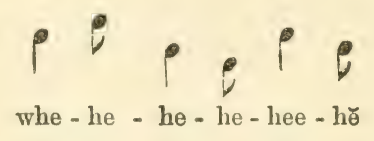

\section{LVII.}

FIELD SPARROW; BUSH SPARROW.

Mr. Burroughs calls the bush sparrow chippy's "country cousin," and when you have once seen him you will agree that no detail could describe him as well. Instead of having a smooth tight fitting coat, his feather's are ruffled up carelessly while the clear ashy breast of chippy is replaced by a rusty one, and his cap is much duller. Altogether his appearance is thoroughly rustic. But he has not only these external marks of the country cousin. Chippy is eminently sophisticated, and assumes "airs," and indulges in petulance that is foreign to the kindly sparrow race. The little bush sparrow, however, is a pleasing contrast. He has a genuine, simple nature, and 
when he sings his sweet song wins your friendship on the spot. But he has one habit that exasperates an observer. There is a field of low bushes on the north side of "Paradise," and I have chased after him through it until I quite forgot that he had any virtues! No sooner would I hear his song, catch a glimpse of a brown back, and creep up softly within opera-glass range, than lo! there he would be hopping about singing from a bush a rod away!

\section{LVIII.}

FOX SPARROW.

In the spring of 1887 the fox sparrows were here for some time, coming occasionally to eat buckwheat on the corn boxes with the tree sparrows and juncos. They were large, fat birds, strikingly bluish-slate about the head, and rich reddish-brown on the wings, lower part of back, and tail. The centres of the breast markings were set in an ochraceous suffusion.

They came to the boxes much more timidly than the other birds, slipping in quietly for a few mouthfuls, as if afraid of being seen. But they made themselves at home in the saplings on the edge of the woods right back of the house, singing in the sun quite fearlessly, even when I was walking about on the crust, staring at them through 
my glass, and taking liberties with their mother tongue. Their song resembled that of the song sparrow in arrangement of note, but was richer, and had a plaintive cast.

\section{LIX.}

\section{BROWN CREEPER.}

AT last we have a bird to put into our empty pigeon-hole, No. 2, - the "creepers." Like the "thrashers and wrens" in No. 10, his prevailing color is brown, and he has a long slender bill, while he resembles the muthatch - his neighbor in No. 12 - in habits. In his way, however, the hrown creeper is a minue bird. He is so nearly the color of the brown bark of the trees you often overlook him as he goes rocking up their sides. When pecking at the bark he looks even more convex than the yellow hammer; for besicles the curve given by his tail as he braces himself by it, and the continuing curve of his back as he bends forward, his bill is long and curved, thus completing the arc.

$\mathrm{He}$ is a systematic workman, going orer his ground in a painstaking fashion, sometimes eren flitting hack a few feet to examine a piece of moss over again. Ile usually begins at the bottom of a tree and works up, sometimes circling. at others flitting up, and again rocking straight up the 
side. He nests as close to the heart of the tree as he can get, little brown wood sprite that he is, ereeping under a bit of loosened bark, or getting into some cramny of the sort, that he can fit up for his white eggs with felt and feather's. 


\section{WARBLERS.}

When you begin to study the warblers you will probably conclude that you know nothing about bir's, and can never learn. But if you begin by recognizing their common traits, and then study a few of the easiest, and those that nest in your locality, you will be less discouraged; and when the flocks come back at the next migration you will be able to master the oddities of a larger number. They belong in pigeon-hole No. 9, - labelled "wood warblers," and are a marked family.

Most of them are very small - much less than half the size of a robin - and are not only short but slender. Active as the chickadee or kinglet, they flit about the trees and undergrow th after insects, without charity for the observer who is trying to make out their markings. Unlike the waxwing, whose quiet ways are matched by its subdued tints, or the uniformly coated kinglets or the greenlets in the pigeon-hole next to them, as a group, the warblers are dashed with all the glories of the rainbow, a flock of them looking as if a painter's palette had been thrown at them. You can see no philosophy or poetry in the bewilder- 
ing combinations, and when you find that they differ entirely with age and sex, you despair of ever knowing them.

Why they should be called warthlers is a puzzle, as a large percentage of them have not as much song as chippy - nothing but a thin chatter, or a shrill piping trill. If you wish a negative conception of them, think of the coloring and habits of the cuclioo. No contrast could be more complete. The best places to look for them during migration are young trees, orchards, and sumny slopes. Here I find them in old orchards, swamps, the raspberry patch, and the edge of the woods. In Northampton they showed an ammoying fondness for pine-tree tops, but atoned for it by giving us the best views of them in the orchards and on the steep bank of Mill River.

\section{LX.}

SUMNIER YELLOW-BIRD; GOLDEN WARBLER; YELLOW WARBLER.

If you have caught glimpses of this little war. bler building in your orchard or the shrubbery of your garden, you may have wondered about his relation to the other yellow-bird - the gollfinch. But when you look at them aritically you will find the two entirely distinct. The golifinch dons a bright canary suit, set off by black (aly), wings's, 


\section{BIRDS THROUGH AN OPERA-GLASS.}

and tail. The summer yellow-bird, on the contrary, wears heavier yellow, and is not only without the contrasting black, but looks dull from the "obsolete" brown streaks on his vest. The goldfinch is a larger bird, and, as he lives on seeds rather than insects, has the thick finch bill instead of the fine one of the warbler. On the wing, at a distance, the peculiar eurved undulating flight of the goldfinch marks him; and when you are near enough to hear him sing, you will find that his canary-like song is totally unlike the warbler trill of the summer yellow-bird.

One spring we discovered a golden warbler's nest in the top of an apple-tree in the old Northampton orchard, near the nest a song sparrow had built at the bottom of a brush heap, and the loose bunch of twigs the catbirds had patched up with newspaper in an apple-tree crotch. Perhaps the little bird thought its persistent enemy, Madam Cowbird, would be less likely to visit its nest if other mother birds were on the watch near by for the golden warbler is the bird spoken of as having had to build three stories to rid itself of the cowbird's eggrs.

\section{LXI.}

REDSTART.

THE long tail of the redstart makes him appear about the size of a chipping bixd. In habits, 
however, he is more like the flycatchers than the sparrows. Indeed, you might imagine that it was from his flycatcher-like way of starting up or falling through the air unexpectedly that he got his name; for then you can see the blotches of rich salmon that mark his wings and tail. However this may be, the rest of his plumage is as striking as his tail. His back is glossy black, and each side of his white breast is ornamenterl with a patch of bright salmon or red. The female, as usual, is plainer than her spouse - has no black on her breast, is olivaceous above, and light yellow where the male is salmon. The young birds are like their mother, only browner above. As the young males begin to put in coat or vest a patch or a gore of their father's color's, they get a ludicrously motley look; and when they finally come out in the full handsome suit of black and red, you imagine them as proud as the college senior with his silk hat.

Like the flycatcher's, the redstarts are fluffy birds and sit with drooping wings. But they show wambler blood by the mad way they career about, opening and shutting their tails fan-fashion, turning somersaults, flitting from branch to branch, stopping a second to give a little burst of song, and then futtering around again; chasing helter-skelter among the bushes; and suddenly falling through the leaves as if they had been shot, only to snap up their prey and dart off to begin their gambols over again. 
They are wimning, friendly little things, and make pretty nests of fine roots, birch bark, and flower cotton, or some such dainty material. According to individual taste, they build in appletree crotches, low roadside bushes, or in saplings

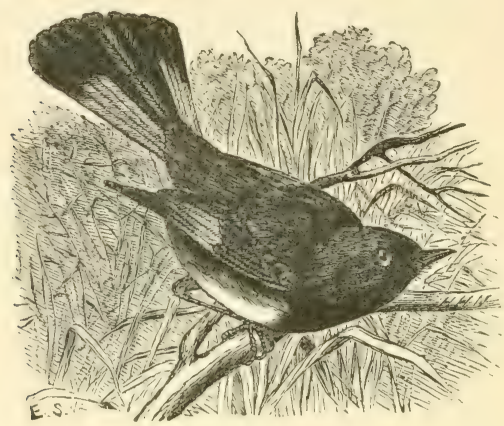

in open woods. In "Paradise" one once built in a loop of grape-vine by the river, and when her gray nest was nearly finished she had a pretty way of sitting inside and leaning over the edge to smooth the outside with her bill and neck, as if she were moulding it. The redstarts take good care to select bark the color of the tree, and in that way defy any but the keenest scrutiny. A little housewife will sometimes fly to her nest with strips of bark four inches long streaming from her bill.

The redstart's song is a fine, hurried warbler 
trill that he accents on the end as if glad it was done.

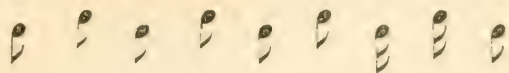

$$
\begin{aligned}
& \text { Te - ka - te - ka - te - ka - te - ka - teek'. }
\end{aligned}
$$

One morning as I was watching a young hairy woodpecker, the solicitude of a redstart diverted me. Keeping up a nervous, worried cry, she eyed me from all sides, and when I moved, followed me in such a significant way that when I had looked through the erotches for her nest without finding it, I concluder the young were out. Father Redstart, - a young male with the scarlet just appearing on the sides of his breast, _ meanwhile, showed about as much paternal anxiety ats Mr. Indigo on similar occasions. Sudklenly I espied one of the baby birds, a wee scrawny, gray thing, sitting on the dead branch of a fallen tree. As I came near him, his mother's terror was pitiful. She flew about as if distraught; now trying to draw me away, she cried out and fluttered her. wing's beseechingly; then, finding that I still kept looking toward the little fellow, she flew lown between us and tried to lure me off. I was very anxious to see if she would "trail," and so was merciless. Walking toward her trembling hird I raised my hand as if to take him, at the same time glancing over at her-behold ! she was trying another device - assuming indifference, as if divining that my interest in her was greater than 
184 BIRDS THROUGH AN OPERA-GLASS.

in her little one. Her eyes were fixed on me, however, and just before the baby flew from my approaching hand, she dashed down and flew about willly, trailing, as I had hoped. It was pitiful to see her distress, and having taken a good look at her I retreated as fast as possible.

Each bird has its own method of decoy: the whippoorwill starts up the leaves that look like her scampering babies; the kingfisher falls on the surface of the water ; and the redstart, instead of spreading her wings and tail and dragging them on the ground as the oven-bird does, spreads and drag's her tail, while she flutters her wings with a tremulous motion, which is much more effective, - suggestive of weakness and helplessness to the hungry animal, who finds a fat, full-grown bind more appetizing than a scrawny youngster ; suggestive of anguish to the man, to whom it seems an appeal for mercy. The love of knowlerlge gave little excuse for treating a poor little mother to such a scare, but I consoled myself by thinking that she would be all the more wary when real danger threatened.

\section{LXII.}

BLACK AND WIITE CREEPING WARBLER.

As his name indicates, this creeper is entirely black and white. Except on the underside of his 
breast, where there is an area of plain white, the colors are arranged mostly in alternate streaks. Although much more slender, the creeper is just about the length of the chickadee, of whom he reminds you by his fondness for tree trunks and branches. His habits of work, though, are much more suggestive of the nuthatch and brown creeper, and as the three are often found together during migration, it is easy to compare them.

The black and white creeper is more active than the others; that is, he has more of the restless warbler habit of flitting. He is not as painstaking nor as systematic as the brown creeper ; and has neither as good head nor feet as the nuthatch. Where the brown creeper would go over a tree trunk twice, to be sure that nothing had escaped him, the black and white creeper will rum up the side of a trunk a little way, then bob about on the branches for a moment, and flit off to another tree. He will hang head down from a branch to peck at the bark, and circle round a small tree horizontally, but I have never seen him go down a tree head first, as the nuthatch does, or walk around the underside of a branch. He will stand and look over the edge of a branch as if trying to see around underneath, but if he conchules to go to the other side he will flit around instead of walking. His song is a high-keyed trill, and as he is protected by being nearly the color of the gray bark he is usually clinging to, it is a grateful help to the discovery of his whereabouts. 
186 BIRLS THROUGH AN OPERA-GLASS.

\section{LXIII.}

BLACKBURNIAN WARBLER; HEMLOCK WARBLER; ORANGE-THROATED WARBLER .

Tre Blackburnian is one of the handsomest and most easily recognized of the warblers. His throat is a rich orange or flame color, so brilliant that it is enough in itself to distinguish him from any of the others. His back is black with yellowish markings. His crown is black, but has an orange spot in the centre; and the rest of his head, except near his eye, is the same flaming orange as his throat. His wings have white patches, and his hreast is whitish, tinged with yellow. His sides are streaked with black. The female and young are duller, the black of their backs being mingled with olive; while their throats are yellow instead of orange.

Now and then you are fortunate enough to get a near view of this exquisite bird, but he has an exasperating fondness for the highest branches of the tallest trees. You can see there is something. up there, but as you throw your head back and strain through your opera-glass, you fancy it is some phantom bird flitting about darkening the leaves. The seconds wear into minutes, but you dare not move. Your glasses don't help you to see through the leares. lut you feel sure that something will appear in a moment, over the edge 
of that spray or on the end of that hare twig, and it won't do to miss it. So when your neckatche becomes intolerahle you fix your eyes immovably on the most promising spot, and step cautionsly backward till you can lean against a tree. The support disappoints you, your hand trembles as much as ever, and your neck is growing stiff. You make a final effort, take your glass in hoth hands, and change your focus, when suddenly a low, fine trill that you recognize from being areented on the end like a redstart's, comes from a branch several feet higher than before orer your hear. Your neck refuses to bend an inch more. You despair. But all at once your tormentor comes tumbling through the leaves after an insect that has gotten away from him, and you catch one fleeting glimpse of orange that more than repays you for all your cramps.

\section{LXIV.}

BLACK-THROATED BLCE WARBLER.

Lrke other ladies, the little feathered bricles have to bear their husbands' names, howerer inat?propriate. What injustice! Here an innocent rreature with an olive-green back and yellowish breast has to go about all her days known as the black-throated blue warblere just becalnse that happens to descrilue the dress of her spouse! 'The' most she has in ammon with him is a white spot 
on her wings, and that does not come into the name at all. Talk about woman's wrong's! And the poor little things camnot even apply to the legislature for a change of name:

You do not blame them for nesting in the mountains and the seclusion of norther'n woods, to get away from the scientists who so ignore their individuality. For in this case it is not their mates who are at fault. They are as pleasing, inoffensive birds as any in the warlbler family, and go about singing their w-ie guttural as they hunt over the twig's and branches, without the slightest assumption of conjugal authority.

Indeed, I saw one last August suing very humbly for his little larly's favor. She was either out of temper, or else inclined to coquette with him. He would fly to her side in a prettily gentle, mobtrusive way, but she would not eren sit on the same branch with him. Off she would go to the next tree. And he would meelily follow after !

The blue-back has a pretty way of turning up his head for a look before he flies to the branch above him, or clambering about by the help of a stem here, or the side of a sapling there, for' as Mr. Burroughs says, he is not a gymmast. He is a winning, trustful little bird, and will often stop his work as you come by, to look at you. 


\section{LXV.}

YELLOW-RUMPED WARBLER; MYTTLE WARBLER.

Dering migration the yellow-rumped is one of the most abundant warblers. It is a hardy, robust-looking bird ; the first of the family to appear in the spring, and one of the last to leave in the fall. You can recognize an adult male very easily in spring, because the black zouave jacket he wears over his white rest has conspicuous white and yellow side pieces.

The yellow-rump is a fearless bird, and frequents undergrowth as well as tree topss, so, if you can induce an adult male to keep still long enough on a spring morning, you will readily note the yellow crown that sets off his slaty-blue back, and the white chin that gives the effect of a choles'. The adult female is dressed in much the same way, but is duller, and offer's less marked contrasts in color. In the winter, like many other birds, they are both much altered - above they are washed with umber brown, and below, a paler wash of the same obscures their summer marking's.

Sometimes you will see large flocks of the yellow-rumped without any other warblers, but as a general thing you will discover a few other species, and sometimes there will be a dozen different kinds together. The myrtle warbler has a coarse 
190 BIRDS THROUGH AN OPERA-GLASS.

z-ie call, and a trill that is heavier than that of the golden warbler.

\section{LXVI.}

\section{CHESTNUT-SIDED WARBLER.}

WHEN I first saw the chestnut-sided warbler he was flitting about the upper branches of the saplings in the raspberry patch, about three rods away, and I put down his yellow cap and wing bars as white, and did not even see the chestnut bands along his sides. I noted his pure white breast, however, and his loud, cheerful whee-liehe, so strikingly unlike the ordinary warbler trill or the z-ie tones of some species. The next day, after looking him up and finding what ought to be there, I discovered, by the help of my glasses, what, in fact, seemed little more than a maroon line beside the wings. But in a few days I found another bird whose chestnut sides were as the books would have them, and I felt like shouting Eureka!

Though I could not detect the nests that should have been in the saplings bordering the clearing, I found plenty of mother chestuuts leading their broods about. They were among the pleasantest acquaintances of the summer. Such charming little birds as they are!

My first hint of what was going on was the sight of one of the dainty little ladies peering at 
me from under the leaves and twig's, with a mouthful of worms. After hunting through the low bushes for some time, I ferreted out some birl's baby, a grayish mite with light wing bars, and wavy shadowy markings across its breast. But it was not until the next day that I had proof that it belonged to my bird. While watching some vireos in the bushes just in the erlge of the clearing, the mother suddenly appeared. Perking up her tail and drooping her wings, she leaned over so as to be able to see me, gave a few little questioning smacks, and then flew down into the bush only a few feet from me, and fed the little bird without fear.

Fear seems to be an instinct, an inheritance with her, but her own confidence is strong enough to conquer it. Indeed, she is altogether sensible. straightforward, industrious, and confiding - a captivating, motherly body.

\section{LXVII.}

MARYLAND YELLOW - THROAT; BLACK - MASKED GROUND WARBLER.

If your walks lead you through low underbrush, weed-grown river banks, alder swamps, or other rough, damp places, you will very likely notice the loud. quick wheé-che-tee, wheé-che-tee, wheé-che-tee that betrays the Maryland yellow- 
throat. He is often shy and you may foliow his voice for a long time and not get a glimpse of the bird, but see him once and you will never forget the picture. You will find him hopping about either on the groumd or near it, for he is truly a ground warbler.

His back is olive-green, with the chin, throat. and breast rich yellow. The forehear is black, and there is a peculiar, mask-like, oblong black patch on each side of his face that extends from the bill back to the neck, and is separated from the dark part of the head loy a strip of ash. The colors of the female are much duller, as she lacks the black patch and the bright yellow.

If you would see the Maryland yellow-throat at his best, you must invade the dense tangle of an alder swamp, so often the fugitive's last refuge, where you can get only mosaic glimpses of blue sky overhear, and camnot distinguish a person twenty feet away: where you must push through the interworen boughs, picking your steps around bogs, over slippery logs and tree trunks, where luxuriant growths of wild grapevine, clematis, and the clinging galium beautify the sturdy alders: where the royal fern, stretching above your waist, flower's in obscurity.

Here, in this secure cover, our little friend seems to lose his timidity and blossoms out in the full beauty of his nature. We find him singing to himself as he runs over the alder boughs, exam- 
ining the leaves with the care of a vireo, or clambering down the side of an alder stalk to hunt at its roots. II hir-pree'-chee-tee, whr-r-pec'-cher-tee, whr-r-ree'-chee-tee, the cheery rich song comes vibrating through the air, to be echoed from the far-off corners of the swamp. We sit down on an old moss-covered log to eat our lunch, and in answer to my call the sociable little warbler comes nearer and nearer till at last he catches sight of us. With what charming curiosity he peer's down at us! What can he his thoughts of the strange intrulers as he takes a half circle to inspect us, first from one point and then from another !

A little further along I come upon a father bird who is even more friendly. He is feeding his hungry little ones, and goes about in a most business-like way hunting for food, but still takes time for an occasional warble. He sees me, but, after a casual survey, keeps on with his work with the calmness of preoccupation, answering my call in a waive, off-hand mamner that is very gratifying:

\section{LXVIII.}

\section{THRUSHES.}

After spending a morning with a flock of warblers, trying to fix your glass on the spot overhead where the leaves stirret, striving to catch the color's of the cap and wing bar's of the 


\section{BIRDS THROUGH AN OPELA-GLASS.}

little object fluttering through the branches of a sapling three or four rods away; making your neck ache looking for the rexatious flitter's that hunt in the tops of the lighest trees; following the hint of a faint chip here, while you keep your eye on half a dozen of the rarer warbler's that have just come in sight orer there; losing track of the whole flock as you stop to sturly the habits of one; and then having to trudge the woods over, straining your ears till convinced that you are deaf, as you try in vain to catch the chicka-dee-dee of the titmouse. or the yong, yany of the nuthatch. which would give a clue to the whereabouts of their companions, the runaways - after a morning spent in this way, you will rome back to the thrushes with a feeling of positive relief.

In the first place, they are large enough to be seen, and give you the full benefit of their size by keeping near the ground. Then, if you find one, he is likely to stay and let you inspect him. Moreover. it is possible to identify him without knowing about each individual tail feather and wing marking. Besides all this, you gain selfrespect in associating with the thrushes. When you have chased after a flock of warblers half a day, only to find. on comparing your notes with descriptions in the books, that what you saw applies equally well to three or four wirlely differing species, your opinion of yourself dwindles 
unpleasantly; depressing doubts creep into your mind. But with the thrushes the case is reversed. You can write essays in your note-book while they sit and look at you. You can arrange their song's in flats and sharps to suit your fancy, and they will not demur.

Doubtless, you must treat them with respect. 'But whoever thought of making a noise in the presence of a philosopher, or taking liberties with a sage? You feel flattered by being allowed to watch them at a distance, and when you get home and find Ridgway's Manual ready to indorse your identifications, your self-respect is restored.

With the thrushes, our pigeon-holes are filled, and it will be well to glance over their labels again before leaving them: No. 1, flycatchers; No. 2, crows, jays, ete. ; No. 3, blackbirds, orioles, etc. ; No. 4, sparrows, finches, etc.; No. 5, tanagers; No. 6, swallows; No. 7, waxwings, etc.; No. 8, vireos; No. 9, wood warblers; No. 10, wrens, thrashers, etc.; No. 11, creepers; No. 12, nuthatches and titmice; No. 13, kinglets, etc.; No. 14, thrushes, etc. What a contrast between the birds in the first hole and those in the last what a distance between the bony, awkwarl flycatchers, with their undeveloped roices, and the shapely dignified thrushes, the nightingales of America!

But in their order, the birds of most of the pigeon-holes show some obvious, extermal relation 
to those in the hole above them. The flycatchers. like the crows and jays, are songless birds; the crows and jays are similar to the hlackbirds and orioles in build and habit; the blackibirds and orioles are linked with the sparrows and finches by the short, conical-billed bobolink and cowbird; the spar'rows and finches resemble the tanagers in general build; the swallows in No. 6 seem to stand alone; but the waxwing's resemble the vireos in elegance and tone of plumage; the vireos approach the wood warblers in size and form; and while there is a natural gap between Nos. 9 and 10, as two families are omitted, the wrens and thrashers are like the creeper's in shape of bill and general coloring; and the creeper is closely comnected with the nuthatch of No. 12, nuthatches and titmice, while the titmice in their turn show the nearness of the family to the kinglets. These resemblances, however, are mostly superficial, not real.

The several thrushes are so closely allied that there is difficulty in discriminating between them, and I confess they puzzled me at first. I began by studying the wood, the hermit, and the tawny. These three all had brown backs, white speckled breasts, and beantiful roices. But before long I found they could be easily distinguished by variations in the shade of brown on their backs, by size and arrangement of the speckles, and by the quality of their songs. 
Coloring of Back.

The brown of the wood thrush is reddest on head and shoulders.

The brown of the hermit is reddest on the tail. The trowny has a uniformly tawny back.

\section{Speckling of Breast.}

The wood is heavily speckled with large brown spots, except on a plain middle area.

The hermit, in keeping with his smaller size, is less heavily marked, with smaller speckles, and has a plain area molerneath, as well as on his neck and breast.

The tawny is only lightly spotted on the sides of his breast, and hats a tawny chin and throat.

\section{Character of Song.}

The rood has a loul, rich, broken song.

The hermit's resembles the wood's in quality, but is much superior. It has a trill inserted in each phrase.

The tawny has a low sweet song consisting of a succession of trills, in descending scale.

In many places the wood thrush is foumd in the most open ground, and the hermit in the densest forest, but this is not always the case.

The most remarkable of the gromps of sweetvoiced birds, the thrushes, are perhaps the most, (ompletely protected, for they are not only inconspicuous in coloring and of quiet halits, but seek the shelter of the forest for a home. 


\section{LXIX.}

WILSON'S THRUSH; VEERY; TAWNY THRUSH.

In Northampton, I have heard the veery sing in the orchard by the river, where the catbird, the song sparrow, the yellow warbler, and the redstart nested, and where the cuckoo, the rose-breasted grosbeak, the yellow-throated vireo, and flocks of migrating warbler's came to call. There it was that the catbird tried to imitate the Wilson's song. Perhaps the indignity drove the thrush on to "Paradise" - in any case, he made his home there, choosing the most beautiful places to sing in, and hoppling about among the ferns over the pine needles that matched the soft brown of his coat.

How well I remember spending one Sunday afternoon in the pine grove, sitting where the ground was strewn with glistening needles, and leaning against a rugged pine trunk flecked by the sunlight. And how when the symphony of wind spirits softly touching their harp strings in the tree tops had soothed every sense into rest and peace, across the grove, from the trees on the hillside and the loushes by the river in antiphonal chorus, rang out the low trilling chant of the veeries.

Here, at home. I know one Wilson's thrush that sings in a locust-tree close to a house by the 
side of the road, apparently indifferent to the baying of hounds, as well as the noisy play of the children; but I have also found others that were shy, even in the seclusion of an alder swamp.

In our woods there are five haunts of the reery. Two are in a dry second growth, one of which is on the western exposure of the woods where the coldest winds sweep over the hill, and little is heard save the woodpecker's reveille and the pensive note of the wood pewee. Here the thrushes' chief occupation is to turn the dry leaves aside with their bills, and scratch among them, ovenbird fashion, for worms. The three other places are moist ferneries, two of them being in the most protected part of the woods. One is in the partridges' cover, the grove of maple saplings where the redstart and the oren-bird nest, and the sun streams in to light up great masses of the arching hairy mountain ferm, and warm the mosscovered drumming $\log$ of the partridge. Another is an old swamp on whose border a giant hemlock stands. Here the red morning sunlight creeps up soon after the birds are awake, and touches caressingly the smooth trunks of the beeches. It always seems as if the reery were more sociable here than on the dark western side of the woods. If you find one ruming along on the dark moss, you are sure to see another standing among the ferms; if you stop to see how the 
sumlight shimmers through the young hemlocks. a friendly kree-ah from a hush near by will prepare you for the low song that trills in descending scale through the cool morning air, and breaks the hush of sumise, as one after another of the peaceful songsters takes it up) and carries it along.

In this swamp, on the soft decayed wood in the top of an old stump, five or six feet from the ground, one of the veeries' nests was found, and I think that careful search might have revealed others. But although such places seem best suited to their tastes, I have found a nest in a locality as dissimilar as could be imagined. It was on the edge of a rasplerry patch where the sum beat down nearly all day long. The nest was deserted when I found it. Such a pretty structure as it was! Within a foot or so of the ground. wedged in hetween the sides of a young beech, it was made almost entirely of old leares, and completely disguised by the (risp) brown ones still rlinging to the twigs. The lining was of dead leaves, roots, and stems. The four eggs were a beautifu', mspotterl. robin's-egg blue. What a pity it seemed that such an attractive little home should be loroken up)! Who will ever know its tragedy! Perhaps the lonely father bird still haunts the woods mouming for his little mate!

In his own quiet way, the reery is a peculiarly sociable bird. So, although his song is the least remarkable of the three thrushes, his conversa- 
tional notes and calls are both varied and numerous. His regular song is a series of trills descending the scale, and may be rendered as a trilled trea, trea, trea. Another form of this is tree, tree, trum, rea, rea.

Last spring I was greatly puzzled by hearing in the woods what seemed like the bleating of a lamb; and although I soon suspected its source, it was some time hefore I son the reery making this peculiar sound. It resembles a bleat so nearly that it can be fairly represented by the syllables bu-ah-ahl. Mr. Brewster says it is a common note from the mountains of North Carolina to Maine and Labrador. I have heard it modified into a rapid run resembling tituree. As far as I have observed, this bleating call is usually comnected with flight, or motion of some kind.

The commonest calls of the reery when undisturbed are kree-ah and hree-up. His kiree'-uhee-u. is in a higher key and suggests alarm. One day I went through the bushes where a family of young were hilling. The mother sat on a branch looking down whisking her tail in dismay. Whee$a 7$ ! she called, and then added in undertone what seemed to be a warning, and sounded like be still, be still!

Sitting on a stump in the rasplberry patch, I have drawn a number of reeries about me by imitating their kree-ah, and one of the rarest forest concerts I ever listened to began with this call. 
It was on a June afternoon, when the sunbeams slanted lazily through the heavy summer air, tipping the fern fronds, and giving a touch of golden enchantment to the brown leaves that strewed the ground. Iree-ah, liree-up, came the sweet, rich call, first from one side and then another, till a dozen thrushes gathered. Then from their leafy covers rose the grave beautiful song. It seemed the choral of a dream, in which each note came forth as an inspiration.

\section{LXX.}

\section{HERMIT THRUSH.}

Is literature and in the field the tawny and hermit thrushes are constantly confounded. The most marked differences have been given, but there are a few lesser points that may be of use in distinguishing them. The back of the hermit is olive, while the tawny, as his name indicates, has a tawny back. The hermit has the habit of raising his tail and then letting it drop straight down, while the tawny raises his tail higher, and lowers it only to the horizontal. The hermit is shy and solitary; the tawny sociable and comparatively conficling. The veery nests in various places; the hermit, almost always on the ground in a swamp, where he builds with leaves, sedges, and moss. 
The call of the tawny is greatly varied, but the hermit has a peculiar, nasal chuck, which, Mr. Bicknell says, suggests "the note of a distant blackbird."

The low, sweet, trilled song of the tawny bears little resemblance to the loud, richly modulated song of the hermit; but as they have been mistaken for each other, it may be well to give the approximate relations of time and note in musical phrase. Like the song of the tawny, the hermit's is divided into three parts, going down the scale. But the trill is, here, only the middle of each phrase

\section{$\rho+p e e^{t r} \rho p e^{t r} \rho$}

Variations from this occur in broken song's, as :

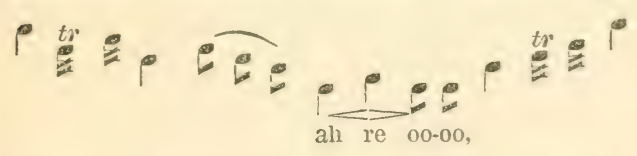

At a little distance this is probably the most beautiful song of our woods. Mr. Burroughs says that to him it is the finest sound in nature. In the Adirondack region the retiring hermit is appromriately known as the "swamp angel."

On the beantiful May morning when we found the red-winged blackbirds " fluting their o-kiclee" over the field of cowsilps, we went on to the woods back of the alder swamp where the wild Howers 
were blossoming. Pushing up through the dead leaves hundreds of yellow adder tongues turned back their petals and darted out their red stamens ; colonies of spring beauties were springing up in the roods, raising their tiny pearl stems, spreading out their two slender green leaves, and opening their delicate crowning cups of pure white or delicate rose. At the foot of the tree trunks cluster's of "ladies and gentlemen," "squirrels' corn," some call them - looked from their luxuriant cover of green leaf filaments. And close to the ground lay the children's shining red fungus "cups and saucers" to light up) the woods. But in the midst of all this mute loreliness the minstrel of the forest came to sing for the flowers their lay of the spring. Sitting almost motionless on the dead branch of a fallen tree top, the thrush poured forth his oh'tir-a-leelee in ever varying tone and melody, till the woods seemed emriched by the marvellous song:

Each bird seems to roice some phase of nature. The bobolink sings for the sunny meadow, the vireo for the shaded tree top, the goldfinch for the blue sky, the indigo-bird for the passing breezes, and the whippoorwill for the night; but the hermit thrush chants the forest Te Deums for sumrise and sunset. Ever since I was a child, in the long summer evenings we have walked through the woods to "William Miller Hill," to see the sumset and listen to the hermit's vespers. 
As we went along, watching the red light slant across the trumks of the trees, we would sometimes be thrilled with his song, but not till we had reached the brow of the hill orerlooking the village in the valley, and the dark line of wooded hills beyond, not till -

"The golden lighting of the sinking sun

O'er which clouds are brightening" -

had all melted away, the sun dropped behind the dark hills, and the rosy (loudlets training across the sky had gradually disappeared; not till the afterglow of the sunset was turning to pale serene light, would the song of the hermit stir us with its full richness and beanty. Then from the wooded hillside it would come to us, filling the cool evening air with its tremulous yearning and pathos, and gathering up into short waves of song the silent music of the sunset-nature's benison of peace. 


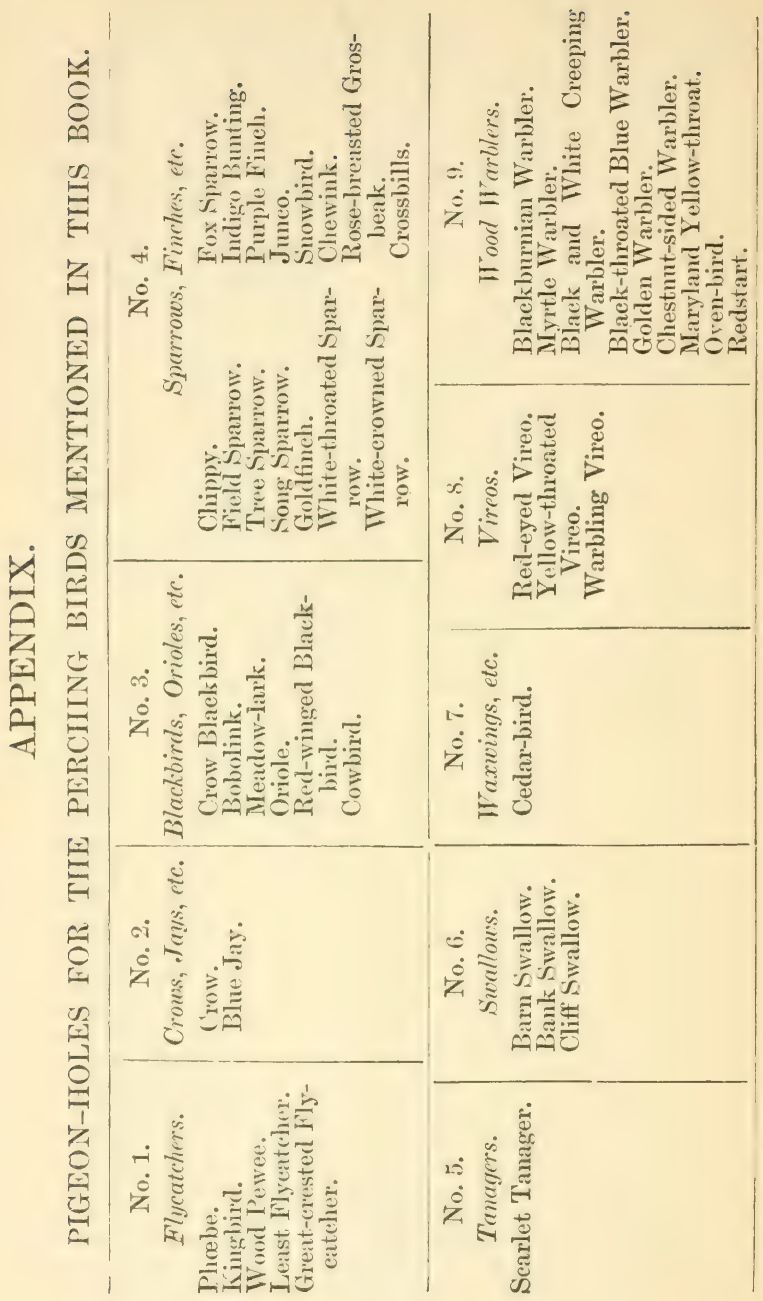



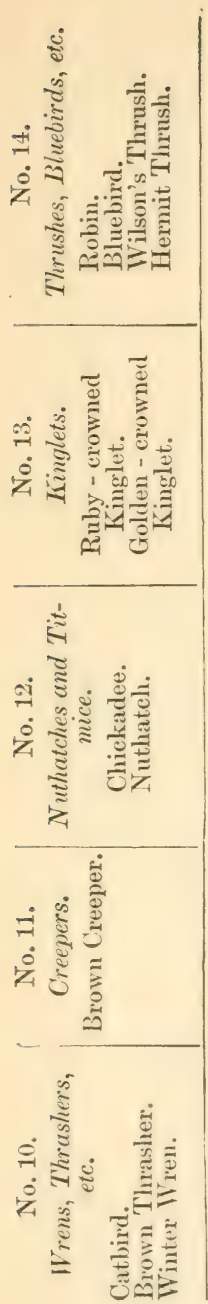

Grouse.

Yellow-billed Cuckoo. Black-billed Cuckoo. Kingfisher.

Hairy Woodpecker.
Downy Woodpecker.

Yellow-bellied Woodpecker. ¿ Red-headed Woodpecker.

Golden-winged Woodpecker. Whippoorwill.

Night-hawk. Swift. Humming-bird. 


\section{GENERAL FAMILY CHARACTERISTICS OF BIRIS TREATED.}

\section{CUCKOOS.}

Long slender birds whose breasts are whitish and backs brown, with a faint bronze lustre. Bill, long and curved. Call, loud and prolonged. Song, wanting. Habits, eccentric - strange silent birds, living in undergrowth or low trees.

\section{KINGFISHERS.}

Large top-heary birds with long crests, slate-blue backs, and white breasts. Bill, very large and strong for holding fish. Flight, rapid and prolonged. Song, a loud hurried trill. Fishermen by oceupation, they live about rivers and lakes, excavating nests in the banks.

\section{WOODPECKERS.}

Plumage, largely black and white. Bill, strong and long for drilling through bark and wood. Flight, noisy, flickering. Call, loud and shrill. Song, wanting, except as they drum on trees, etc. Habits, phlegmatic, most of time spent clinging, erect, to sicles of tree trunks. (Exception, yellow hammer : plumage, brownish, instear of black and white ; song, a loud full trill ; habits, more like ground woodpeckers ; haunts ant-hills, fields, and fence-posts, etc.)

\section{GOATSUCKERS.}

Mottled brownish and grayish birds, with tiny bills and enormous mouths for catching insects on the wing. Nest, wanting - eggrs laid on bare ground or leaves.

\section{SIVIFTS.}

Sooty or blackish birts that live on the wing, never lighting except in chimneys, towers, or hollow trees where 
they roost and nest. Bills small, mouths large, as in the goatsuckers.

\section{HUMMING-BIRDS.}

Diminutive birds whose plumage shows brilliant metallic lustre. Bills, slender and elongated for reaching insects and nectar at bottom of flower tubes. Flight, rapid, darting.

\section{FLYCATCHERS.}

Dull, gray birds with big heads and shoulders. Males and femiles similar in plumage. Bills, hooked at end. Songless or with short song (woorl pewee, three notes). Habits, hunt by lying in wait for insects and then springing at them with nervous spasmodic morements. (Exception, lingbird.) Largely silent and motionless when not watching for food.

\section{CROWS AND JAYS.}

Large conspicuous birds, with strong bill and claws. Songless but clamorous. Active and boisterous - especially the blue jay.

\section{BLACKBIRDS AND ORIOLES.}

Plumage, striking, black prominent. (Exception, meadowlark.) Females generally duller, and in some cases smaller than males. Bills and claws, strong; hills, long and conical. (Exceptions, bobolink and cowbird, whose bills are short and conical.)

\section{SPARROWS AND FINCHES。}

Fine songsters. Bills, short, stout, cone-shaped, for cracking seeds.

Sparrous. - Comparatively small, dnll-plumaged bircls, with striped backs; much the color of the ground and bushes on which they live - males and females similar.

Finches. - Bright-plumaged birds, females duller than males. 
TANAGERS.

Shy, brilliantly-colored birds, with dull-plumaged wives. They build low, but hunt for worms and sing their loud swinging song mostly in the cover of tree tops.

\section{SWALLOWS.}

Small-billed, big-mouthed insect eaters. Not songless, yet without musical power. When not flying they often perch on telegraph wires and the ridge-poles of barns.

\section{WAXWINGS.}

Elegant, delicately-tinted birds. Usually silent and retiring. They practise among themselves amazing courtesy and gentleness.

\section{VIREOS.}

Small olive-green or gray-backed, white-breasted birds ; much the color of the lights and leaf tints they live among. Bills, long and slender for holding worms. Songs, loud and continuous, from their tree-top covers. Nests pensile and delicate.

\section{WARBLERS.}

Plumage, mostly rariegated and brilliant. Females generally duller than males. Song; in many cases only a trill. Food, insects. Habits, nervous, restless.

\section{WRENS AND THRASHERS.}

Small and large birds that sing their brilliant songs secure in the protection of their inconspicuous brown or gray dress and the dense thickets or forest undergrowth they frequent. As they spend little time in flight their wings are short, but the long tails of the thrashers are of great use in helping them along from bush to bush.

CREEPERS,

Small obscure brown hirds that spend their time ereep- 
ing up and down tree trunks, from which they get their living and in which they nest. Bill long, slender and curved. 'Tails stiff and bristly for bracing them as they work-like the woodpeckers'.

NUTHATCHES AND TITS.

Small tree birds usually found together in flocks except when breeding.

Nuthatches. - Slate-blue-backed birds that walk serlately up and down tree trunks, and rum along branches upside down, like flies.

Chickadees. - Fluffy grayish biruls that Hit among tree tops

\section{KINGLETS.}

Small fluffy greenish birds that flit about the leaves of shrubbery and trees after insects. Songs remarkable.

\section{THRUSHES}

Brown-backed, white-breasted birds, size of robin, or smaller. Bills, long and slender, fitted for worm diet. Habits, phlegmatic ; pensive birds, fond of sitting motionless. Finest of American songsters.

\section{ARBITRARY CLASSIFICATIONS OF BIRDS DE- SCRIBED.}

\section{Birds found in Certann Localities.}

1. About or near houses. - Robin, chipping sparrow, song sparrow, junco, chimney swift, erow blackbird, warbling vireo, yeliow-bellied woodpecker, tree sparrow, hrown creeper. oriole, phohe, purple finch, chickadee, cathird, resl-eyed vireo, nuthatch, humming-bird, barn swallow.

2. In gardens and orchards. - Cathird, bluebird. waxwing, cuckoo, oriole, kingbird, kinglets, humming-hirr. warbling vireo, yellow-throated vireo, rellow-bellied wood- 
pecker, purple finch, goldfinch, summer yellow-bird, warblers, cowbird, least flyeatcher, yellow hammer.

3. In ficlds and meadous. - Meadow-lark, cowbird, nighthawk, crow, bank swallow, barn swallow, cliff swallow, vesper sparrow, field sparrow, bobolink, red-winged blackbird, snowflake, song sparrow.

4. In bushes and clearings. - White-throated sparrow, song sparrow, chipping sparrow, tree sparrow, field sparrow, white-crowned sparrow, junco, Maryland yellow-throat, kinglets, chewink, brown thrasher, rose-breasted grosbeak, catbird, robin, purple finch, goldfinch, winter wren.

5. By streams and rivers. - Phobe, waxwing, bank swallow, kingfisher, yellow warbler, red-winged blackbird, Naryland yellow-throat, whippoorwill, harn swallow, bank swallow, cliff swallow.

6. In roords. - Thrushes, wood pewee, oven-bird, black and white creeper, woodpeckers, junco, nuthatch, grouse, great-crested flycatcher, chewink, whippoorwill, tree sparrow, fox sparrow, brown creeper, scarlet tanager, chickadee, Blackburnian warbler, crossbills, vireos, reclstart, blackthroated blue warbler, yellow-rumped warbler, winter wren.

7. Edge of woords. - Rose-hreasted grosbeak, cowbird, redstart, wood pewee, woodpeckers, kingbird, euckoo, ovenbird, bluebird, humming-bird, chickadee, chewink, greaturested flycatcher, brown thrasher, yellow-bellied woodpecker, tree sparrow, white-throated sparrow, white-crowned sparrow, fox sparrow, brown creeper, thrasher, vireos, oriole, purple finch, junco, warblers, yellow hammer, winter wren.

S. Roarlside fences. - Bluebird, flicker, kinghird, redheaded woodpecker, goldfinch, white-crowned sparrow, field sparrow, vesper sparrow, song sparrow, white-throated sparrow.

9. Thirkets. - White-throated sparrow, song sparrow, Maryland yellow-throat, chickidee, jumer, whewink. brown thrasiner, white-crowned sparrow, field sparrow, catbird, 
iTilson's thrush, warblers (in migration), winter wren (in migration), chestnut-sided warbler.

10. Pine uoorls. - Warblers, kinglets, chickadce, brown thrasher, whippoorwill, white-crowned sparrow, erossbills, purple finch, nuthatch, woodpeckers.

\section{Size COMPARED WITH THE RoBIN.}

\section{SMALLER THAN THE ROBIN.}

1. Less than half as large. - Kinglets, chipping sparrow, goldfinch, chickadee, nuthatch, warblers, winter wren, least flycatcher, humming-bird, tree sparrow, field sparrow, hrown creener, yellow-throated vireo, warbling vireo.

2. About half as large. - Swift, red-eyed vireo, oven-bird, erossbills, wood pewee, purple tinch, song sparrow, junco, indigo-bird.

3. More than half as large. - Phœbe, bluebird, waxwing, downy woodpecker, barn swallow, bank swallow, eliff swalIow, vesper sparrow, white-crowned sparrow, fox sparrow, white-throated sparrow, bobolink, oriole, searlet tanager, snow bunting.

\section{ABOUT THE SAME SIZE AS THE ROBIN.}

Rose-breasted grosbeak, cowbird, red-headed woodpecker, hairy woodpecker, yellow-bellied woodpecker, chewink, great-crested flycatcher, red-winged blackbird, catbird, thrushes, kingbird.

\section{LARGER THAN THE ROBIN.}

Yellow hammer, kingfisher, crow, grouse, brown thrasher, whippoorwill, meatlow-lark, cuckoo, night-hawk, keel-tailed blackbird, blue jay. 


\section{Colors.}

\section{COLORS STRIKING OR BRIGHT.}

1. Blue backs. - Blue jay, bluebird (azure blue), nuthatch (slate-blue), kingfisher (slate-blue), indigo-bird, blackthroated blue warbler, barn swallow (steel-blue).

2. Chestnut or red breasts. - Bluebird, robin, crossbills (male), scarlet tanager (male), chewink.

3. Yellow or orange throats. - Blackburnian warbler, Maryland yellow-throat, summer yellow-bird, yellow-throated vireo.

4. Yellow or orange breasts. - Yellow - throated vireo, summer yellow-bird, goldfinch, oriole, meadow-lark, Blackburnian warbler, Maryland yellow-throat.

5. Red patch on top or back of head in males. - Rubycrowned kinglet, woodpeckers, kingbird.

6. Red heads (entire head and neck red or madder pink). Red-headed woodpecker, purple finch (old males), crossbills (males).

7. Birds wholly or largely black (males). - Crow, blackbirds, cowbird, redstart (salmon patches on breast, wings, and tail), bobolink (whitish patehes on nape of neck and back), rose-breasted grosbeak (earmine patch on breast, helly white), chewink (white breast, brown sides), oriole (orange below).

\section{COLORS DULL OR PLAIN.}

1. Upper parts olive-green. - Breast unspotted: Kinglets (patch of red or yellow in crown), vireos (top of head unmarked), tanager (female), crossbills (females). Breast spotted: Oven-bird (crown patch orange-brown bordered with black).

2. Upper parts olive-gray. - Cuekoos (tail very long, bill curved), great-crested flycatcher.

3. Upper parts dusky grayish-olive. - Phœbe (length about 
seven inches), wood pewee (length about six inches), least flycatcher (length about five inches).

4. Upper parts brown. - a. Back without markings of any kind: Indigo-bird (female), brown thrasher (breast spotted, tail very long), Wilson's thrush (breast spotted, tail short), hermit thrush (breast spotted, tail short and red), winter wren (back barred).

$b$. Back more or less streaked: Meadow-lark (below yellow with black collar), female rose-breasted grosbeak (rose of male replaced by saffron yellow), bobolink (female and male in winter, buffish-yellow below), purple finch (female), brown creeper, grouse.

Sparrows: c. Breast unspotted in adult: Chipping (crown brick red), white-throated (yellow syot in front of eye), white-crowned (crown-cap of five lines), field sparrow (rusty look).

d. Breast spotted or streaked: Song (no white on tail). tree (breast with spot in centre, cap reddish).

5. General color chiefly black and white. - a. In large patches or areas: Snowflake, bank swallow, rose-breasted grosbeak (male), redstart (male), chewink (brown sides), red-headed woodpecker (head and neck red).

b. In stripes. Black and white creeper.

c. In spots (above, white below) : Hairy woodlpecker, downy woodpecker.

6. Yellow band across end of tail. - Waxwing (high crest).

7. White band across and of tail. - Kingbird (low crest).

8. Crown and throat black (size small). - Chickadee (back dull ash-gray).

9. General color sooty. - Chimney swift.

10. General color slate. - Catbird, junco (belly and outer tail feathers white).

BRIILIANT MALES CHANGING TO DULL COLORS OF FEMALES IN AUTUMN.

Bobolink (becomes : almost sparrowy in appearance), gold- 
finch (becomes flaxen-brown above and brownish-yellow be low), scarlet tanager (becomes greenish-yellow), yellowrumped warbler (becomes brownish).

\section{BIRDS SHOWING WHITE ON TAIL FEATHERS IN FLIGIIT.}

Meadow-lark, vesper sparrow, junco, chewink (white t!iangles on corner's of tail), rose-breasted grosbeak, several warblers, kingbird (white crescent bordering tail).

\section{Songs.}

SINGERS.

1. Particularly plaintive. - Bluebird, white-throated sparrow, hermit thrush, meadow-lark, wood pewee.

2. Especially happy. - Bobolink, song sparrow, goldfinch. indigo-bird, chickadee.

3. Short songs. - Robin, chickadee, bluebird, Maryland yellow-throat, meadow-lark, great-crested flycatcher, whippoorwill, white-crowned sparrow.

4. Long songs, with definite beginning, middle and end.Hermit thrush, indigo-bird, thrasher, chewink, song, field, tree, fox, white-crowned, and white-throated sparrows.

5. Long songs, without definite beginning, midrle, and end. - Purple finch, catbird, golifinch, warbling vireo.

6. Long loud songs. - Oriole, scarlet tanager, oven-bird, rose-breasted grosbeak, chewink, winter wren, brown thrasher.

\section{TRILLERS.}

(Saying tee-ka-tee-ka-tee-ka, or words to that effect.)

Low. - Redstart, summer yellow-bird, black and white creeper, junco, chippy, brown creeper, swift (saying chippychippy-chirio), nuthatch.

Loud. - Yellow hammer (if-if-if-if-if-if-if), kingfisher (alarm), oven-bird (saying teacher). 


\section{Peculiarities of Flight.}

Conspicuously tail-steering : Keel-tailed blackbird.

Undulated flight: Goldfinch, woodpeckers, snowbird, bluebird.

Circling flight : Swallows and night-hawks.

Labored flight: Bobolink, meadow-lark, sparrows.

Fluttering flight : Chimney swift.

Particularly direct flight : Robin, crow, keel-tailed blackbird, kingfisher, oriole, blue jay.

VI. Birds witi Habit of Soxg-Flight.

Cowbird, bobolink, oven-bird, bluebird, kingbird, swift, woodpecker, red-shouldered blackbird, indigo-bird, song sparrow, Maryland yellow-throat, meadow-lark, kingfisher, euckoo, goldfinch, night-hawk, purple finch.

\section{MARKED Habits.}

1. Pllegmatic, merlitative, fond of sitting quietly. - IVaxwing, robin, thrushes, white-throated sparrow, meadow-lark, wood pewee, woodpeckers, swallows, kingfisher.

2. Restless, constantly flitting about. - Winter wren, kingrlets, chickadee, warblers.

3. Loquacious. - Catbird, purple finch, crow blackbird, blue jay, red-eyed vireo, warbling vireo, oven-bird, swift, chippy, bobolink.

\section{Birds that WalK INSTEan of Hopprag.}

Keel-tailed blackhird, red-winged blackbird, erow, partridge, cowbird, oven-bird, meatow-lark. 


\section{Shape of Bill adapted to Food.}

1. Short and stout, for cracking seeds. - Grosbeak, crossbills (crossed for getting out spruce and pine seeds), purple finch, indigo-bird, junco, snow bunting, bobolink, sparrows, chewink.

2. Long and slender for holding worms. - Thrushes, warblers, orioles, kinglets, brown creeper.

3. Hoolied at end to hold insects. - Vireos, flycatchers.

4. Long and heavy for drilling holes in trees. - Woodpeckers.

j. Slender and delicate for reaching insects at bottom of flower tubes. - Humming-bird.

6. Large and long for holding fish. - Kingfisher.

\section{Where Certain Birds Nest.}

1. On the ground. - Meadow-lark (meadows and fields), white-throated sparrow, partridge, snow bunting, nighthawk, bobolink, junco, oven-bird, song sparrow, hermit thrush, Maryland yellow-throat, black and white ereeper, chewink, whippoorwill, vesper sparrow.

2. In holes. - $a$. Holes in trees and stubs: Woodpeckers, nuthatch, chickadee, bluebird, great-crested flycatcher.

b. Holes in river and other banks: Kingfisher, bank swallow.

3. In orchards. - Kingbird, goldfinch, waxwing, summer yellow-bird, chipping sparrow, catbird, robin, blue jay, redstart, cuckoo, least flycatcher.

4. About houses, sheds, and barns. - Robin, phœbe, eave swallow, chimmey swift, bluebird (in knot-holes in out houses or in bird boxes), chipping sparrow.

כ. In bushes. - Cuckoo, chipping sparrow; catbird, rosebreasted grosbeak, red-eyed vireo, Wilson's thrush, redwinged blackbird, song sparrow, yellow warbler, indigo bunting, brown thrasher. 
6. In low trees. - Tanager, chestnut-sided warbler, yellow warbler, redstart, red-eyed vireo, purple finch, kingbird, humming-bird, least flycatcher.

7. In high trees. - Robin, oriole (especially in elms), erow, erow blackbird, purple finch, vireos, woorl pewee, Blackburnian warbler, crossbills, humming-bird.

8. In other birds' nests. - Cowbird, cuckoo (rarely).

9. In crevices of logs or stumps. - Winter wren.

10. Under bark on trees. - Brown creeper.

XI. Birds that are seen in Flocks when yot NrstING.

Cedar-bird, night-hawk, bobolink, white-throated sparrow, junco, chickadee (small parties), nuthateh (small parties), blue jay (small parties), red-headed woodpecker, crossbill, purple finch, bluebird, goldfinch, kinglet, warblers, snowbird, blackbird, chimney swift, crow, swallows, resper sparrow, tree sparrow, grouse. 



\section{BOOKS FOR REFERENCE.}

A. O. U. Check-List of North American Birds, $1895, \$ 2.00$; abridged edition, 25 cents. L. S. Foster, New York. Audubon, John James. Birds of America ; Urnithological

Biography. (Both out of print.)

Baird, S. F., T. IT. Brewer, and R. Ridguray. A History of North American Birds. J vols. Little, Brown \& Co., Boston. $\$ 48.00$.

Bendire, Chas. E. Life Histories of North American Birds. ¿2 vols. Smithsonian Institution, Washington. \$15.00. Chapman, Frank IT. Handbook of Birds of Eastern North America. I). Appleton \& Co., New York. $\$ 3.00$; pocket edition, 83.50. Bird-Life. D. Appleton \& Co.,

New York. 81.7\%. With colored plates, 85.00.

('omes, Elliutt. Key to North American Birds. Dana Estes \& Co., Boston. $\$ 7.50$.

Elliot, Daniel Gr. The Gallinaceons (iame Birds of North America. Francis P.. Iarper, New York. \$2.jo.

Herrian, Florence A. Birds of Village and Field. Houghton, Mifflin \& Co., Boston. \$2.00.

Minot, II. D. The Land-Birds and (rame-Birds of New England. Second edition, edited by William Brewster. Houghton, Mifflin \& Co., Boston. \$3.50.

Nehrling, Henry. Our Native Birds of Song and Beauty. ㅡ rols. (ieorge Brumder, Milwaukee. Lnbound, $\$ 16.00$; bound, $\$ 18.00-\$ 22.00$.

Nuttall, Thomas. A Mamual of the Ornitloology of the Lnited States and Canadia. (Out of print.) A Popular Irandbook of the Ornithology of Eastern North America, being a new edition of the Mamnal of Ornithology revised and annotated by Montague Chamberlain. 2 vols. Little, Brown \& ('o., Boston. $\$ 7.50$. 
liedguay, Robert. A Manual of North American Birds. J.

B. Lippineott Co., Philadelphia. $\$ \mathbf{7} .50$.

Wilson, Alexander. American Ornithology. (Out of print.) Wright, Mabel Osyoorl. Birderaft. The Macmillan Co., New York. $\$ 2.50$.

Wright, Habel Osgood, and Elliott Coues. Citizen Bird. The Macmillan Co., New York. \$1.50.

\section{PERIODIC ALS.}

Auk, The. A Quarterly Journal of Ornithology. Published for the American Ornithologists' 'Tnion by L. S. Foster, New York. $\$ 3.00$ per annum.

Osprey, The. An Illustrated Monthly Magazine of Ornithology. The Osprey Company, New York. \$1.()() per annum.

\section{BOOKS CONTAINING ORNITHOLOGICAL ESSAYS AND SKETCHES.}

Bolles, Frank. Land of the Lingering Snow ; At the North of Bearcamp Water; From Blomidon to Smolyy. Houghton, Miffin \& Co., Boston. \$1.25 each.

Burroughs, John. Wake-Robin; Winter Sunshine; Birds and Poets; Locusts and Wild Honey ; Pepacton ; Fresh Fields; Signs and Seasons; Riverby. Houghton, Mifflin \& Co., Boston. \$1.25 each.

Miller, Olive Thorne. Bird Ways; In Nesting Time; Little Brothers of the Air ; A Birl-Lover in the West ; Upon the Tree-tops. Houghton, Mifflin \& Co., Boston. $\$ 1.25$ each.

Robinson, Rowland E. In New England Fields and Woods. Houghton, Mifflin \& Co., Boston. \$1.25.

Torrey, Bradford. Birds in the Bush ; A Rambler's Lease ; The Foot-Path Way ; A Florida Sketch-Book; Spring Notes from Tennessee : A World of Green Hills. IIoughton, Mifflin \& C'o., Boston. \$1.25̃ each. 


\section{INDEX.}

AMERICAN goldfinch, 76-80.

Arbitrary classification of birds described, 211-219.

Baltimore oriole, $52-54$.

Bank swallow, 165, 166.

Barn swallow, 55-57.

Bay-winged bunting, 171, 172.

Bee martin, 83-85.

Belted kingfisher, 57-60.

Bill, shape of, adapted to food, 218.

Blackbird, bronzed, 20-27.

crow, 20-27, 107.

keel-tailed, 20-27.

red-winged, 89-92, 107.

Blackbirds and orioles, general characteristics, 209.

Blackburnian warbler, 186, 187.

Black-capped chickadee, 42-15.

Black-masked ground warbler, 191193.

Black-throated blue warbler, 187, 188.

Black and white creeping warbler, $184,185$.

Bluebird, 14-16.

Blue jay, 69-75.

Bobolink, 27-32, 107.

Bronzed grackle, 20-27.

Browu creeper, 176, 177.

Brown thrasher, 150-153.

Bull-bat, 169-171.

Bunting, bay-winged, 171, 172. snow, 144,145 .

Bush sparrow, 174, 175.

Catbird, 18-20.

Cedar-bird, 112-115.

Chestnut-sided warbler, 190, 191.

Chewink, 115-119.

Chickadee, black-capped, 42-45.

Chimney swallow, 16-18. swift, 16-18.

Chip-bird, 60-66.

Chipping sparrow, 60-66.

Chippy, 60-66.

Classification, by colors, 214-216.
Classification by localities, 211-213.

by marked habits, 217 .

by nesting habits, 218,219 .

by peculiarities of flight, 217 .

by shape of bill, 218.

by size, 213 .

by song, 216 .

Cliff swallow, 166.

Colors, classification by, 214-216.

Cowbird, 105-108.

Creeper, brown, $176,177$.

Creepers, general characteristics, 210, 211.

Crossbills, 166-169.

Crow, 10-13.

rain, $46,47$.

blackbird, 20-27, 107, 108.

Crows and jays, general characteristics, 209

Cuckoo, 46, 47.

Cuckoos, general characteristics, 208.

Devil-down-head, 100-105.

Downy woodpecker, 99, 100.

Eave swallow, 166.

Field sparrow, 174, 175.

Finch, grass, 171, 172. purple, $122,123$.

Finches, general characteristics, 209.

Fire-bird, 52-51.

Flicker, 48-51.

Flight, peculiarities of, 217.

Flycatcher, great-crested, 163-165. kingbird, 83-\$5.

least, 87-89.

Flycatchers, general characteristics, 209.

Fox sparrow, 175, 176.

Goatsuckers, general characteristics, 208.

Golden-crowned thrush, 132-138.

Golden robin, 52-5t.

Golden warbler, $179,180$.

Goldfinch, American, 76-80. 
Grackle, bronzed, 20-27.

Grass finch, 171, 172.

Great-crested flycatcher, 163-165.

Grosbeak, rose-breasted, 153, 154.

Grouse, ruffed, 32-35.

Hair-bird, 60-66.

Hairy woodpecker, 92-98.

Hangnest, 52-5t.

Hemlock warbler, 186, 187.

Hermit thrush, 202-205.

Humming-bird, ruby-throated, 36-40.

Humming-birds, general characteristics, 209.

Indigo-bird, 119-122.

Jay, blue, 69-75.

Jays, general characteristics, 209.

Junco, 138-140.

Keel-tailed blackbird, 20-27.

Kingbird, 83-85.

Kingfisher, belted, 5i-60.

Kingfishers, general characteristics, 208.

Kinglets, 140-144. general characteristics, 211.

Lark, meadow, 40-42.

Least Hycatcher, 87-89.

Localities, classification by, 211.

Marked habits, 217.

Martin, bee, 83-85. sand, 165, 166.

Maryland yellow-throat, 191-193.

Neadow-lark, 40-42, 107, 108.

Myrtle warbler, 189, 190.

Nesting habits, classification by, 218, 219.

Night-hawk, 169-171.

Nuthatch, white-bellied, 100-105.

Nuthatches, general characteristics, 211.

Orange-throated warbler, 186, 187.

Oriole, 52-5t, 107, 108.

Orioles, general characteristics, 209.

Oven-bird, 132-138.

Partridge, 32-35.

Peculiarities of flight, 217.

Pewee, wood, 85-87.

Phobe, S0-83.

Pigeon-holes for perching birds, 206, 207.

Purple finch, 122, 123.

Rain crow, $46,47$.

Red-eyed vireo, 124-129.
Red-headed woodpecker, 159, 160.

Redistart, 180-184.

Red-winged blackbird, 89-92, 107 , 108.

Reed-bird, $27-32$.

Rice-bird, 27-32.

Robin, 4-10. golden, $52-54$

Rose-breasted grosbeak, 153, 154.

Ruby-throated humming-bird, 36-40. Ruffed grouse, 32-35.

Sand martin, 165, 166.

Sapsucker, yellow-bellied, 160-163.

Scarlet tanager, 146-150.

Shape of bill adapted to food, 218 .

Size compared with the robin, 213 .

Slate-colored snowbird, 138-140.

Snowbird, ate-colored, 138-140.

Snow bunting, 14t, 145.

Snowflake, 144, 145.

Social sparrow, 60-66.

Songs, elassification by, 216 .

Song flight, 217.

Song sparrow, 66-68.

Sparrow, bay-winged, 171, 172.

bush, 174,175 .

chipping, 60-66.

field, 174, 175 .

fox, 175,176 .

junco, 138-140.

social, 60-66.

song, 66-68.

tree, $172,173$.

vesper, 171,172 .

white-crowned, 173, 174.

white-throated, 109-111.

Sparrows, general characteristics, 209.

Summer yellow-bird, 179, 180 .

Swallow, bank, $165,166$.

barn, 55-57.

chimney, 16-18.

cliff, 166.

eave, 166 .

Swallows, general characteristics, 210.

Swift, chimney, 16-18.

Swifts, general characteristics, 208, 209.

Tanager, scarlet, 146-150.

Tanagers, general characteristics, 210 .

Tawny thrush, 19S-202.

Thistle-bird, $76-80$.

Thrasher, brown, 150-153.

Thrashers, general characteristics, 210.

Thrush, golden-crowned, 132-138.

hermit, 202-205.

tawny, 198-202. 
Thrush, veery, 198-202.

Wilson's, 198-202.

Thrushes, general characteristics, 193-197, 211. means of distinguishing, $19 \pi$.

Titmouse, 42-45.

Tits, general characteristics, 211 .

Towhee, 115-119.

Tree sparrow, 172, 173.

Veery, 198-202.

Vesper sparrow, 171,172 .

Vireo, red-eyed, 12t-129. warbling, 131, 132. yellow-throated, 129, 130.

Vireos, general characteristics, 210.

Warblers, blackburnian, 186, 187. black-masked ground, 191-193. black-throated blue, 187, 188 . black and white creeping, 184, 185.

chestnut-sided, 190, 191.

golden, 179, 180.

hemlock, 186, 187.

Maryland yellow-throat, 191193.

myrtle, 189, 190.

orange-throated, 1S6, 187.

redstart, 180-184.

summer, 179, 180.

Jellow, 179,180 .
Warblers, yellow-rumped, 189, 190. general characteristics, 178, $179,210$.

where to look for, 179.

Warbling vireo, $131,132$.

Waxwing, 112-115.

Waxwings, general characteristics, 210.

Whippoorwill, 155.

White-bellied nuthatch, 100-105.

White-crowned sparrow, 173, 174.

White-throated sparrow, 109-111.

Wilson's thrush, 198-202.

Winter wren, 155-159.

Woodpecker, downy, 99, 100. hairy, 92-98. red-headed, 159, 160. yellow-bellied, 160-163.

Woodpeckers, general characteristics; 208.

Wood pewee, 85-87.

Wren, winter, 155-159.

Wrens, general characteristics, 210.

Yellow-bellied sapsucker, 160-163.

Yellow-bird, 76-80. summer, 179, 180.

Yellow hammer, 4S-51.

Yellow-rumped warbler, 189, 190.

Yellow-throated vireo, 129,130 .

Yellow warbler, 179, 180. 




$8^{2}$

Pol 59 

SMITHSONIAN INSTITUTION LIBRARIES

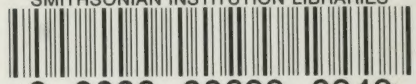

3 9088006990949 